NISTIR 7785

\title{
Modeling and Simulation of Critical Infrastructure Systems for Homeland Security Applications
}

Charles McLean

Y. Tina Lee

Dr. Sanjay Jain

Dr. Charles Hutchings

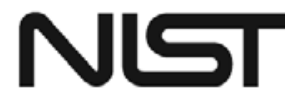


NISTIR 7785

\title{
Modeling and Simulation of Critical Infrastructure Systems for Homeland Security Applications
}

\author{
Charles McLean \\ Y. Tina Lee \\ Manufacturing Systems Integration Division \\ Engineering Laboratory \\ Dr. Sanjay Jain \\ George Washington University \\ Dr. Charles Hutchings \\ U.S. Department of Homeland Security
}

September 2011

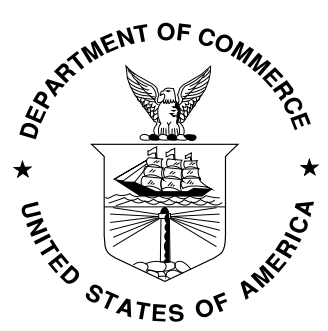

U.S. Department of Commerce Rebecca M. Blank, Acting Secretary

National Institute of Standards and Technology Patrick D. Gallagher, Under Secretary for Standards and Technology and Director 


\section{ACKNOWLEDGMENTS}

The U.S. Department of Homeland Security Science and Technology Directorate sponsored the production of this material under Interagency Agreements HSHQDC-09-X-00009 and HSHQDC-09-X00357 with the National Institute of Standards and Technology (NIST). The work described was funded by the United States Government and is not subject to copyright.

\section{DISCLAIMERS}

The findings expressed or implied in this report do not necessarily reflect the official view or policy of the U.S. Department of Homeland Security, U.S. Department of Commerce, or the United States Government.

Some software products may have been identified in context in this report. This does not imply a recommendation or endorsement of the software products by the authors or NIST, nor does it imply that such software products are necessarily the best available for the purpose.

Comments or questions about this report may be e-mailed to: simresponse@cme.nist.gov. 


\section{Contents}

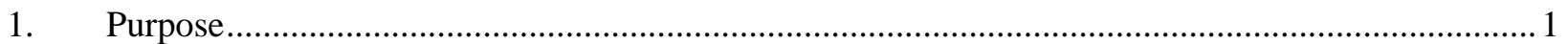

2. Introduction to Critical Infrastructure and Key Resources (CIKR) .............................................. 2

3. Perspectives on Methodologies, Models, and Simulations ...................................................... 6

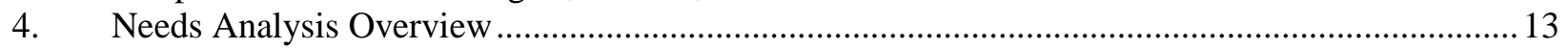

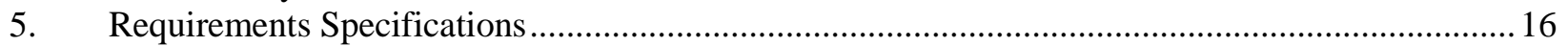

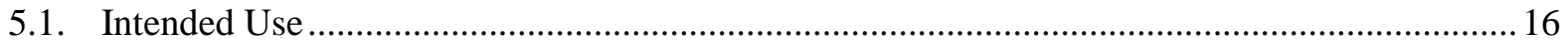

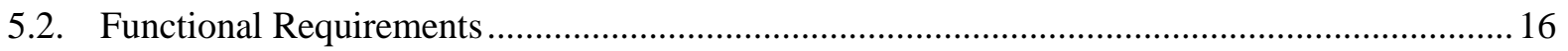

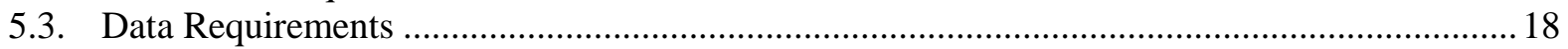

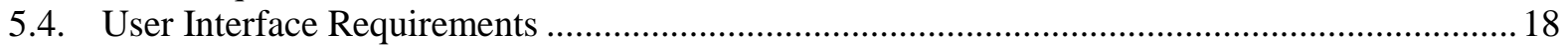

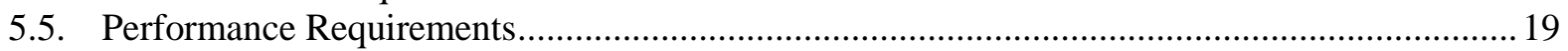

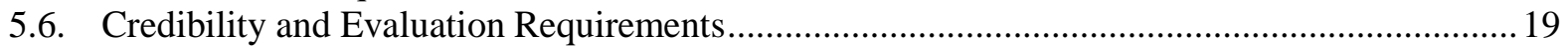

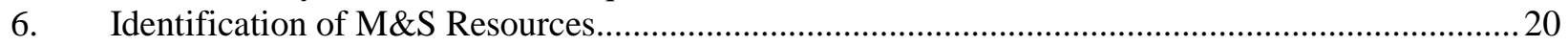

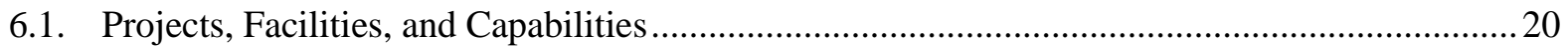

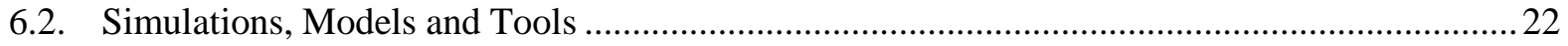

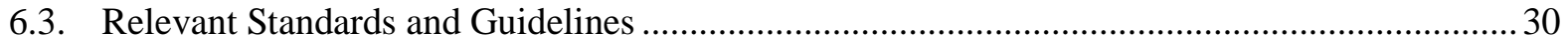

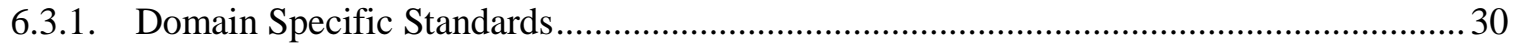

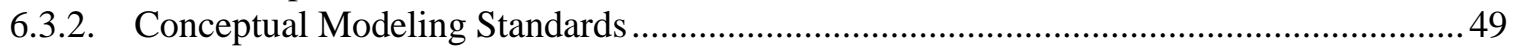

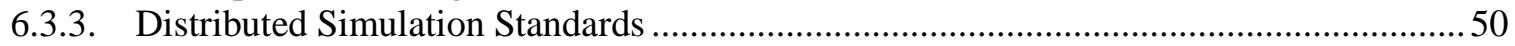

6.3.4. Selected Geographic Information System (GIS) Standards............................................ 51

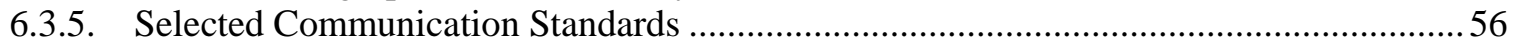

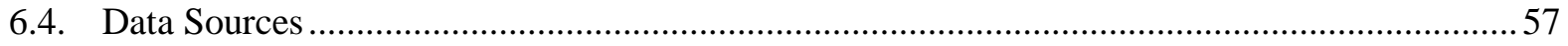

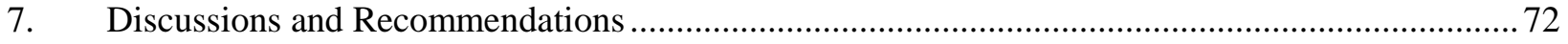

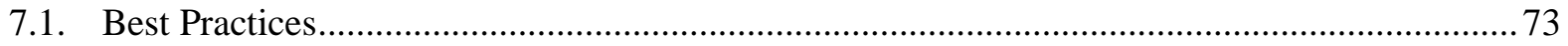

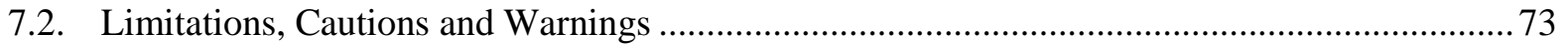

7.3. Research, Development, Standards and Implementation Issues............................................... 73

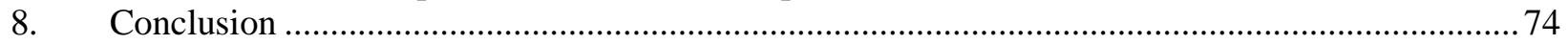

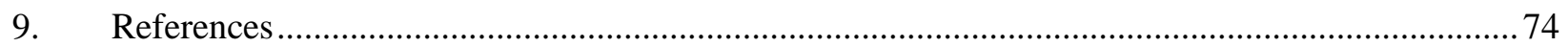


This page left blank intentionally. 


\section{Purpose}

Critical Infrastructure and Key Resources (CIKR) models and simulations may be used to understand infrastructure systems, their interdependencies, their vulnerabilities, and the impact of the propagation of damage across interdependent infrastructure systems based upon emergency incidents. They may also be used to support training exercises, performance measurement, conceptual design, impact evaluation, response planning, analysis, acquisition, conceptualizing and evaluating new systems, vulnerability analysis, economic impact, and determining interdependencies between CIKR systems. The goal of this document is to capture the current knowledge and information resources that can serve as a common baseline for researchers and developers of models and simulations of CIKR for homeland security applications. This initial version of the document attempts to assemble relevant, publicly available information from a number of sources within U.S. Department of Homeland Security (DHS) and the modeling and simulation (M\&S) communities.

This document is intended to help initiate the discussion of the current leading research, development, standards, and implementation issues within the CIKR M\&S community. The document will be updated based on the input of domain experts across government, research, and commercial organizations. These experts will be invited to join together in a workshop to review and extend this document for its final publication. The workshop will focus on simulation and modeling activities and needs that support analysis, planning, and training for the CIKR sectors as well as the integration of M\&S applications across the sectors. Issues to be addressed within the scope of this workshop include the establishment of consensus on:

- identification of subject matter experts

- definition of customer and user needs

- $\quad$ system requirements specifications

- recommended/approved modeling techniques and approaches

- identification of data sources, reference data sets, formats, and standards

- identification of appropriate model evaluation and accreditation practices

The workshop will also help identify the current leading research, development, standards, and implementation issues. Such analysis by the workshop participants may be found to be relevant by future efforts for developing standards, conducting research and development, and enhancing implementation policies and procedures for homeland security applications of M\&S to improve the protection of critical infrastructure systems.

This document provides a compendium of information that has been assembled that is relevant to the M\&S of CIKR. CIKR, as defined by DHS, are introduced in Section 2. Section 3 provides a general background on methodologies, models, and simulations. An initial set of high level user and customer needs for M\&S applications in the CIKR domain is presented in Section 4. Section 5 translates the high level needs to a representative set of M\&S system requirements (a more detailed specification is currently under development in a related effort). The existing CIKR M\&S resources and capabilities such as projects, tools, standards, and data sets that have been developed over the years to meet the needs and requirements are identified in Section 6. Section 7 presents a discussion of issues, concerns, and recommendations for advancing $M \& S$ for critical infrastructure protection emanating from a comparison of current resources and capabilities with the needs and requirements. Section 8 concludes the document while section 9 provides list of references used.

Three additional documents have been prepared as a part of this effort. The other documents address M\&S for incident management, healthcare systems, and release of hazardous materials. To minimize 
redundancy between the documents, each document focuses on the M\&S techniques that are most significant to the sectors mission and objectives. The CIKR document emphasizes modeling and simulation supporting analysis of systems (e.g., vulnerability, security), whereas the incident management document focuses more on training and exercises. The healthcare systems document addresses M\&S for analysis, training, and exercises, but at a more detailed level than the previous two documents. The hazardous material release document focuses on the more physical aspects of M\&S associated with explosions, fires, plumes, and the flow of hazardous materials in building ventilation systems, bodies of water, and the soil. The authors recognize that each of the sectors may employ all of the M\&S techniques that have been identified in the other documents, but typically to a lesser extent.

The authors welcome identification of omissions as well as suggestions for improvements. Please contact the authors directly or submit comments or questions by e-mail to simresponse@cme.nist.gov.

\section{Introduction to Critical Infrastructure and Key Resources (CIKR)}

The National Infrastructure Protection Plan (NIPP) [DHS 2009] provides the structure needed to coordinate, integrate, and synchronize activities derived from various relevant statutes, national strategies, and Presidential directives to create a unified national approach to implementing the CIKR protection mission (see Figure 1). The relevant authorities include those that address the overarching homeland security and CIKR protection missions, as well as those that address a wide range of sector-specific CIKR protection-related functions, programs, and responsibilities. Homeland Security Presidential Directive 7 (HSPD-7) established U.S. policy for enhancing CIKR protection by establishing a framework for NIPP partners to identify, prioritize, and protect the nation's CIKR from terrorist attacks. The directive identified 17 CIKR sectors and designated a federal Sector-Specific Agency (SSA) to lead CIKR protection efforts in each. The directive allows for the U.S. Department of Homeland Security to identify gaps in existing CIKR sectors and establish new sectors to fill these gaps. Under this authority, the Department established an 18th sector, the Critical Manufacturing Sector, in March 2008.

Protecting and ensuring the continuity of CIKR are essential to the nation's security, public health and safety, economic vitality, and way of life. Critical Infrastructures are the assets, systems, and networks, whether physical or virtual, so vital to the nation that their incapacitation or destruction would have a debilitating effect on security, national economic security, public health or safety, or any combination thereof. Key Resources are publicly or privately controlled resources essential to the minimal operations of the economy and government [DHS 2009].

The NIPP identifies CIKR sectors and responsible agencies. The sectors and responsible agencies are identified below:

1. Agriculture and Food - This sector is defined as the supply chains for feed, animals, and animal products; crop production and the supply chains of seed, fertilizer, and other necessary related materials. It includes the post- harvesting components of the food supply chain, from processing, production, and packaging, through storage and distribution to retail sales, institutional food services, and restaurant or home consumption. (Responsible Agencies: Department of Agriculture, Department of Health and Human Services)

2. Banking and Finance - This sector includes institutions that provide the following products and services: deposit, consumer credit, and payment systems; credit and liquidity products, investment products, and risk-transfer products, including insurance. (Responsible Agency: Department of the Treasury) 


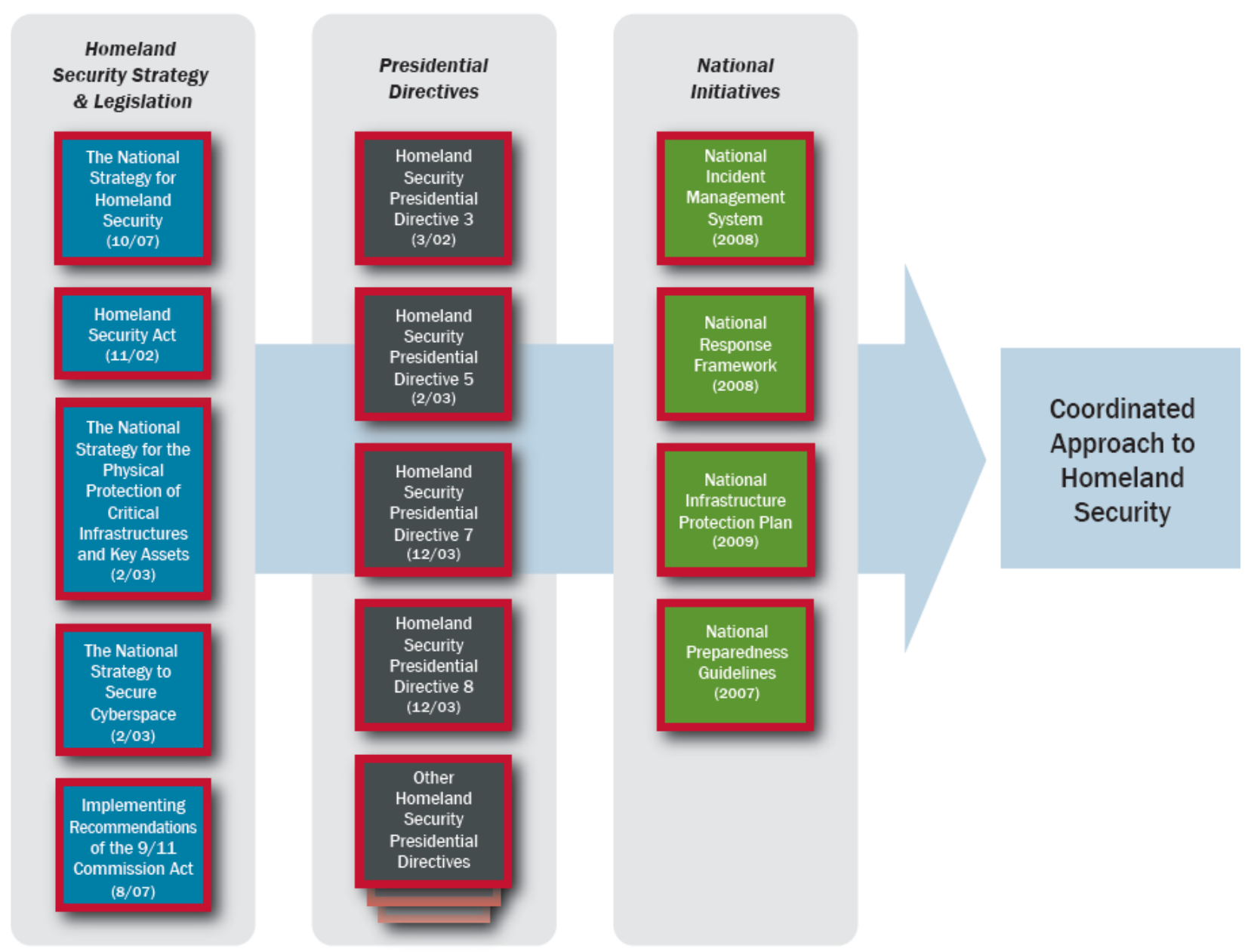

Figure 1: National Framework for Homeland Security (from [DHS 2009])

3. Chemical -This sector can be divided into five main segments, based on the end product produced: basic chemicals, specialty chemicals, agricultural chemicals, pharmaceuticals, and consumer products. (Responsible Agency: Department of Homeland Security - Office of Infrastructure Protection)

4. Commercial Facilities - This sector consists of the following eight subsectors: public assembly (e.g., arenas, stadiums, aquariums, zoos, museums, convention centers); sports leagues (e.g., professional sports leagues and federations); resorts (e.g., casinos); lodging (e.g., hotels, motels, conference centers); outdoor events (e.g., theme and amusement parks, fairs, campgrounds, parades); entertainment and media (e.g., motion picture studios, broadcast media); real estate (e.g., office/apartment buildings, condominiums, mixed-use facilities, self-storage); and retail (e.g., retail centers and districts, shopping malls). (Responsible Agency: Department of Homeland Security Office of Infrastructure Protection)

5. Communications - This sector includes physical properties such as wire line, wireless infrastructure, satellite, cable, and broadcasting and also services such as the Internet, information services, and cable television networks. (Responsible Agency: Department of Homeland Security - Office of Cybersecurity and Communications)

6. Critical Manufacturing - This sector includes manufacturers that design, produce, and distribute products not covered by other sectors, including: primary metals (e.g., iron and steel mills and ferroalloy manufacturing, alumina and aluminum production and processing, nonferrous metal, except aluminum, production and processing); machinery (e.g., engines, turbines, and power transmission 
equipment); electrical equipment, appliances, and components; transportation equipment (e.g., motor vehicles, aerospace product and parts, railroad rolling stock, and other transportation equipment). (Responsible Agency: Department of Homeland Security - Office of Infrastructure Protection)

7. Dams - This sector comprises the assets, systems, networks, and functions related to dam projects, navigation locks, levees, hurricane barriers, mine tailings impoundments, or other similar water retention and/or control facilities. It provides a wide range of economic, environmental, and social benefits, including hydroelectric power, river navigation, water supply, wildlife habitat, waste management, flood control, and recreation. (Responsible Agency: Department of Homeland Security - Office of Infrastructure Protection)

8. Defense Industrial Base - This sector is subdivided into segments, sub-segments, and commodities that produce or comprise weapon system platforms, components, and expendables. Major segments include missile, aircraft, troop support, space, combat vehicle, ammunition, weapons, information technology, shipbuilding, and electronics. Commodities include mechanical components and systems, structural elements, electrical, and electronics. (Responsible Agency: Department of Defense)

9. Emergency Services - This sector is a system of response and recovery elements that forms the nation's first line of defense and prevention and reduction of consequences from any terrorist attack. It is a sector of trained and tested personnel, plans, redundant systems, agreements, and pacts that provide life safety and security services across the nation via the first-responder community comprised of federal, state, local, tribal, and private partners. First-responder disciplines included within the sector are: emergency management, emergency medical services, fire, hazardous material, law enforcement, bomb squads, tactical operations/special weapons assault teams, and search and rescue. (Responsible Agency: Department of Homeland Security - Office of Infrastructure Protection)

10. Energy - The energy infrastructure is divided into three interrelated segments: electricity, petroleum, and natural gas. More than 80 percent of the country's energy infrastructure is owned by the private sector. The sector's reliance on pipelines highlights the interdependency with, and the reliance on, the Energy Sector for power, which means that virtually all sectors have dependencies on this sector. (Responsible Agency: Department of Energy)

11. Government Facilities - This sector includes a wide variety of buildings, owned or leased by federal, state, territorial, local or tribal governments, located domestically and overseas. Many government facilities are open to the public for business activities, commercial transactions, or recreational activities. Others not open to the public contain highly sensitive information, materials, processes, and equipment. This includes general-use office buildings and special-use military installations, embassies, courthouses, national laboratories, and structures that may house critical equipment and systems, networks, and functions. (Responsible Agencies: Immigration and Customs Enforcement, Federal Protective Service)

12. Healthcare and Public Health - This sector consists of state and local health departments, hospitals, health clinics, mental health facilities, nursing homes, blood-supply facilities, laboratories, mortuaries, and pharmaceutical stockpiles. (Responsible Agency: Department of Health and Human Services)

13. Information Technology (IT) - This sector is comprised of virtual and distributed functions necessary to provide IT products, and services including hardware, software, IT systems, and services. (Responsible Agency: Department of Homeland Security - Office of Cybersecurity and Communications)

14. National Monuments and Icons - This sector is comprised of a diverse array of assets located throughout the United States and its Territories - many are listed on either the National Register of Historic Places or the List of National Historic Landmarks. They include monuments, physical structures, or objects that are: 1) recognized both nationally and internationally as representing the Nation's heritage, traditions, and/or values or are recognized for their national, cultural, religious, historical, or political significance; and 2) serve the primary purpose of memorializing or 
representing significant aspects of our Nation's heritage, traditions, or values and serve as points of interest for visitors and educational activities. These assets generally do not have a purpose or function that fits under the responsibility of another sector. (Responsible Agency: Department of the Interior)

15. Nuclear Reactors, Materials, and Waste - The sector includes: nuclear power plants; non-power nuclear reactors used for research, testing, and training; nuclear materials used in medical, industrial, and academic settings; nuclear fuel fabrication facilities; decommissioning reactors; and the transportation, storage, and disposal of nuclear material and waste. (Responsible Agency: Department of Energy)

16. Postal and Shipping - The sector moves over 720 million messages, products, and financial transactions each day. Postal and shipping activity is differentiated from general cargo operations by its focus on small- and medium-size packages and by service from millions of senders to nearly 150 million destinations. Sector-specific assets include: high-volume automated processing facilities; local delivery units; many and varied collection, acceptance, and retail operations; mail transport vehicles including vans, trucks, tractor trailers and aircraft; and information and communications networks. Every sector of the economy depends on the service providers in this sector to deliver time-sensitive letters, packages, and other shipments. (Responsible Agency: Department of Homeland Security - Transportation Security Administration)

17. Transportation Systems - This sector comprises all modes of transportation (aviation, maritime, mass transit, highway, freight rail, and pipeline) - a vast, open, interdependent networked system that moves millions of passengers and millions of tons of goods each year. (Responsible Agencies: Department of Homeland Security - Transportation Security Administration, United States Coast Guard)

18. Water - This sector includes drinking water and wastewater utilities, facilities, and systems. (Responsible Agency - Environmental Protection Agency)

To ensure an effective, efficient $\mathrm{CI} / \mathrm{KR}$ protection program over the long term, the NIPP relies on the development, safeguarding, and maintenance of data systems and simulations to enable continuously refined risk assessment within and across sectors and to ensure preparedness for domestic incident management. In particular, the complexity of interdependency calls for use of modeling and simulation capabilities. DHS Office of Infrastructure Protection (IP) is the lead coordinator for modeling and simulation capabilities regarding CIKR protection and resiliency [DHS 2009]. In this capacity, DHS has several objectives including:

- Specifying requirements for the development, maintenance, and application of research and operations related modeling capabilities for CIKR protection and resiliency

- Utilizing available relevant modeling and simulation capabilities in training and exercises to familiarize the Sector Specific Agencies (SSAs) and other CIKR partners with them

- Providing guidance on the vetting of modeling tools

- Promoting use of applicable private sector modeling capabilities, including initiatives and expertise, by DHS, SSAs and their CIKR partners

The principal capability within the IP to support modeling, simulation, and analysis efforts is the National Infrastructure Simulation and Analysis Center (NISAC). NISAC has been tasked to develop advanced modeling, simulation, and analysis capabilities for the Nation's CIKR. These tools and analyses together address CIKR in all-hazards context including physical and cyber dependencies and interdependencies. These sophisticated models better inform decision-makers, especially for cross-sector priorities. NISAC is the principal but not the sole source available to CIKR stakeholders in need of modeling, simulation and analysis capabilities. NISAC works with other providers of CIKR analysis to improve overall analytical quality and ensure consistency. 
Information regarding sector-specific CIKR-related authorities is addressed in the respective Sector Specific Plans (SSPs). The SSPs provide the means for implementing NIPP across all sectors. SSPs also provide a national framework for each sector that guides the development, implementation, and updating of State and local homeland security strategies and CIKR protection programs [DHS 2009]. As the responsible agent for the identification of assets and existing databases for their sectors, the SSAs' objectives include:

- Outlining the sector plans and processes for database, data system, and modeling and simulation development and updates in their respective SSPs; and

- Facilitating the collection and protection of accurate information for database, data system, and modeling and simulation use in collaboration with sector partners.

Fourteen of the SSPs are publicly available. The limited current capabilities identified in these SSPs suggest that there are large opportunities for use of M\&S in each of the sectors.

\section{Perspectives on Methodologies, Models, and Simulations}

Concise Oxford Dictionary of Current English, 1996, defines Methodology as “a body of methods used in a particular activity.” Methodology is principles of method, and such principles can be used to study and inform problem solving and decision-making. [Checkland 2000] describes a useful model linking methodology and the user of a methodology to problem solving:

'A problem-solving situation with three elements:

- A user of methodology (this assumes that the user is familiar with the methodology)

- Methodology as documented

- Situation as perceived by the user

Relationship and interactions between the three elements are encapsulated in the LUMAS model (Learning, User of methodology, Methodology formally described, Actual approach adopted, and real world problem Situation) shown in figure 2. A simple example narrative for the diagram may be: A user, $U$, appreciating a methodology, $M$, as a coherent set of principles and perceiving a problem situation, S, asks, “what can I do?" The User then tailors from $M$ a specific approach, $A$, judged to be appropriate for $S$, and uses it in an attempt to improve the situation. This generates learning, $L$, which may change the user, $U$ or the methodology, $M$.

A methodology is, then, a logical framework that not only brings forth learning for an individual, but does so in a consistent and systemic manner so learnings can be shared and passed on.'

Another perspective on methodology comes from the International Council on Systems Engineering (INCOSE) where methodology is defined as "a collection of related processes, methods and tools" [INCOSE 2008]. This is based on definitions from [Martin 1996]:

'Methodology can be differentiated from other related concepts using the following definitions from [Martin 1996]:

- A Process $(P)$ is a logical sequence of tasks performed to achieve a particular objective. A process defines "WHAT" is to be done, without specifying "HOW" each task is performed. The structure of a process provides several levels of aggregation to allow analysis and definition to be done at various levels of detail to support different decision-making needs. 


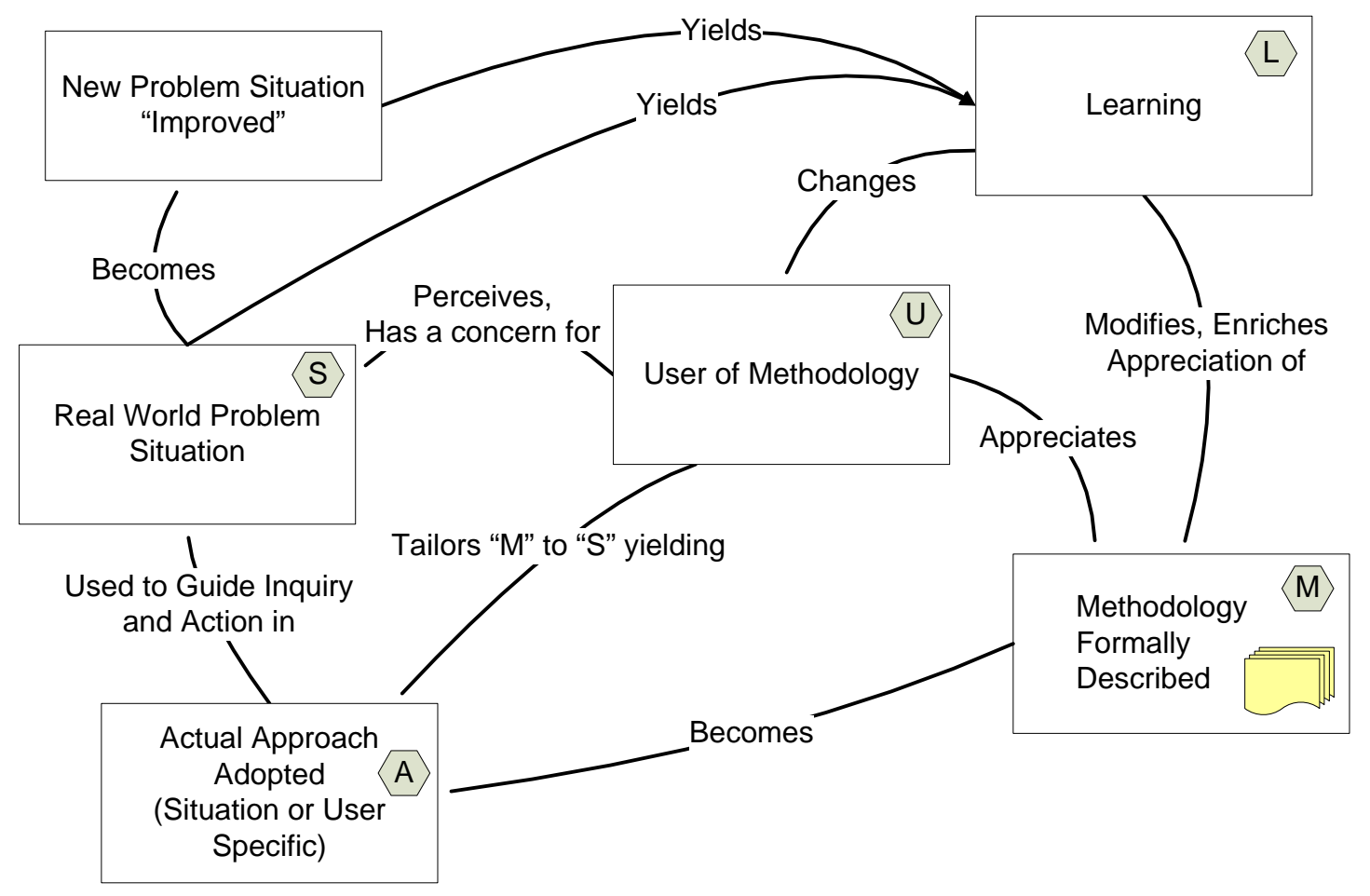

Figure 2: The LUMAS Model (from [Checkland 2000])

- A Method (M) consists of techniques for performing a task, in other words, it defines the "HOW" of each task. (In this context, the words: "method," "technique," "practice," and "procedure" are often used interchangeably.) At any level, process tasks are performed using methods. However, each method is also a process itself, with a sequence of tasks to be performed for that particular method. In other words, the "HOW" at one level of abstraction becomes the "WHAT" at the next lower level.

- A Tool (T) is an instrument that, when applied to a particular method, can enhance the efficiency of the task; provided it is applied properly and by somebody with proper skills and training. The purpose of a tool should be to facilitate the accomplishment of the "HOWs." In a broader sense, a tool enhances the "WHAT" and the "HOW." Most tools used to support systems engineering are computer- or software-based, and are also known as Computer Aided Engineering (CAE) tools.

Closely associated with methodology is an Environment (E) that consists of the surroundings, the external objects, conditions, or factors that influence the actions of an object, individual person or group [Martin 1996]. These conditions can be social, cultural, personal, physical, organizational, or functional. The purpose of a project environment should be to integrate and support the use of the tools and methods used on that project. An environment thus enables (or disables) the "WHAT" and the "HOW".'

The interrelationship of processes, methods, tools, and environments is graphically represented in Figure 3 .

Using systems engineering as an example, one model of a systems engineering process is provided by the NIPP Risk Management Framework shown in Figure 4. 

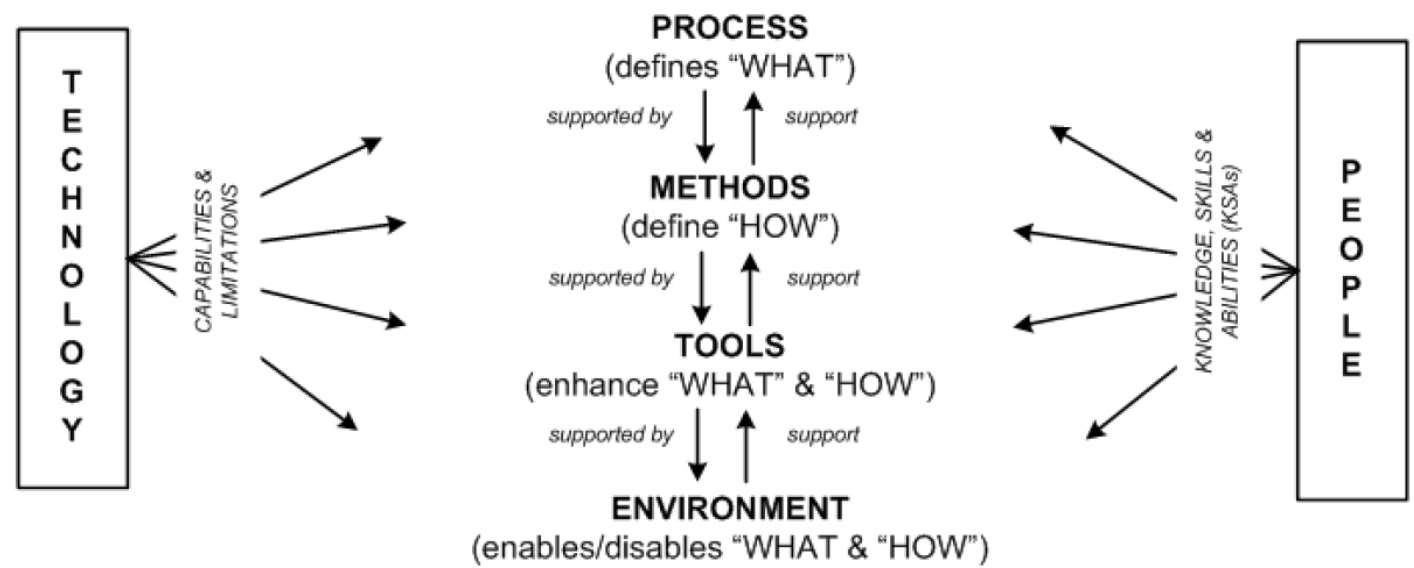

Figure 3: The Process, Methods, Tools, Environments Elements, and Effects of Technology and People (from [INCOSE 2008])

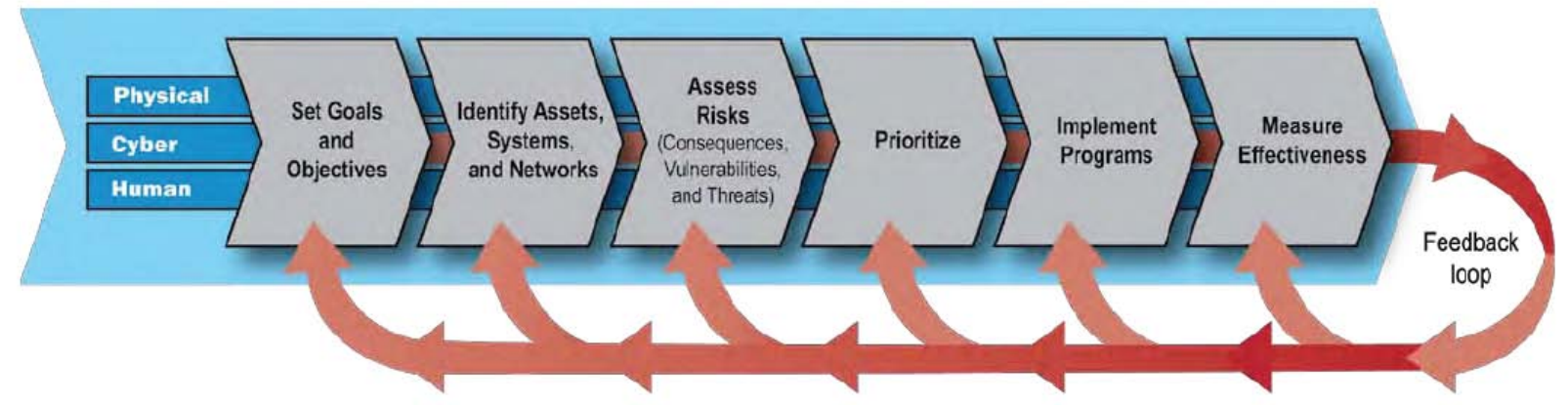

Continuous improvement to enhance protection of CIKR

Figure 4: NIPP Risk Management Framework (from DHS [2009])

The NIPP risk management framework uses several methods and sub-processes that support this process such as:

- Development of the national, state, regional, and sector risk profiles to facilitate setting goals and objectives

- Maintaining the inventory of CIKR and associated attributes through the Infrastructure Information Collection System (IICS), a federated integrated data warehouse (IDW), accessible in a geospatial context using the capabilities provided by the Integrated Common Analytical Viewer (iCAV) suite of tools, including the iCAV and DHS Earth viewers

- Important resilient and redundant security measures that apply to the IDW and provide system integrity and security, software security, and data protection

- Constellation/Automated Critical Asset Management System (C/ACAMS) to help State and local officials leverage their knowledge to create infrastructure inventories, implement practical CIKR protection programs, and facilitate information sharing within and across State and local boundaries, as well as with DHS and other Federal partners

- Strategic Homeland Infrastructure Risk Assessment (SHIRA) process, an annual collaborative process to assess and analyze the risks to the Nation's infrastructure from terrorism, as well as natural and manmade hazards 
- Assessment of risk based on consequence, vulnerability and threats

- Sophisticated models and simulations to identify dependencies and interdependencies within and across sectors

- Cyber Security Vulnerability Assessment (CSVA), a flexible and scalable approach that analyzes an entity's cybersecurity posture and describes gaps and targeted considerations that can reduce overall cyber risks

- Vulnerability Assessment (VA) project to develop and deploy a scalable assessment methodology for identifying vulnerabilities, supporting collaborative security planning, and recommending protective measures strategies

- Federal Emergency Management Agency (FEMA) Manual 452, Risk Management: A How-To Guide to Mitigate Potential Terrorist Attacks Against Buildings, to assess the risk to and mitigation for hundreds of buildings and museums

The National Infrastructure simulation and Analysis Center (NISAC) has developed a number of M\&S tools which support the NIPP risk management framework. Users of the NIPP methodology document apply the elements in various ways depending on the questions that they need to address. For example, the SSPs tailor the NIPP for specific concerns in each CIKR sector.

"Model” and "simulation" can be defined or classified in many ways. For example, the DHS Lexicon [DHS 2010] includes the following definitions:

- Model: approximation, representation, or idealization of selected aspects of the structure, behavior, operation, or other characteristics of a real-world process, concept, or system.

- Simulation: model that behaves or operates like a given process, concept, or system when provided a set of controlled inputs.

In addition, Department of Defense glossary [DoD 2010] provides the following definition.

- Modeling \& Simulation: Modeling and Simulation (M\&S): The discipline that comprises the development and/or use of models and simulations. M\&S is highly dependent upon Information Technology as defined in DoD Directive 4630.05, Interoperability and Supportability of Information Technology (IT) and National Security Systems (NSS), May 5, 2004.

a. The use of models, including emulators, prototypes, simulators, and stimulators, either statically or over time, to develop data as a basis for making managerial or technical decisions. The terms "modeling" and "simulation" are often used interchangeably, but simulations generally execute models over time, space, events, or other processes.

The focus of this document is on computer models and simulations - computer implemented physical, mathematical, process, phenomenological or other types of models. The way in which computer models and simulations support methodology is modeled in Figure 5 ( $\mathrm{M}$ in the LUMAS Model).

Models can broadly be divided into structural and behavior representations of systems, which could include mathematical or empirical modeling. Each of these types of models can be implemented using computer models for simulation and used to study questions of interest about a particular system. Various examples of model types are shown. This list of model types is not complete or exhaustive, but is meant to show typical applications of M\&S that support methodologies such as operations research, systems engineering, experimentation, or other types of analysis. 


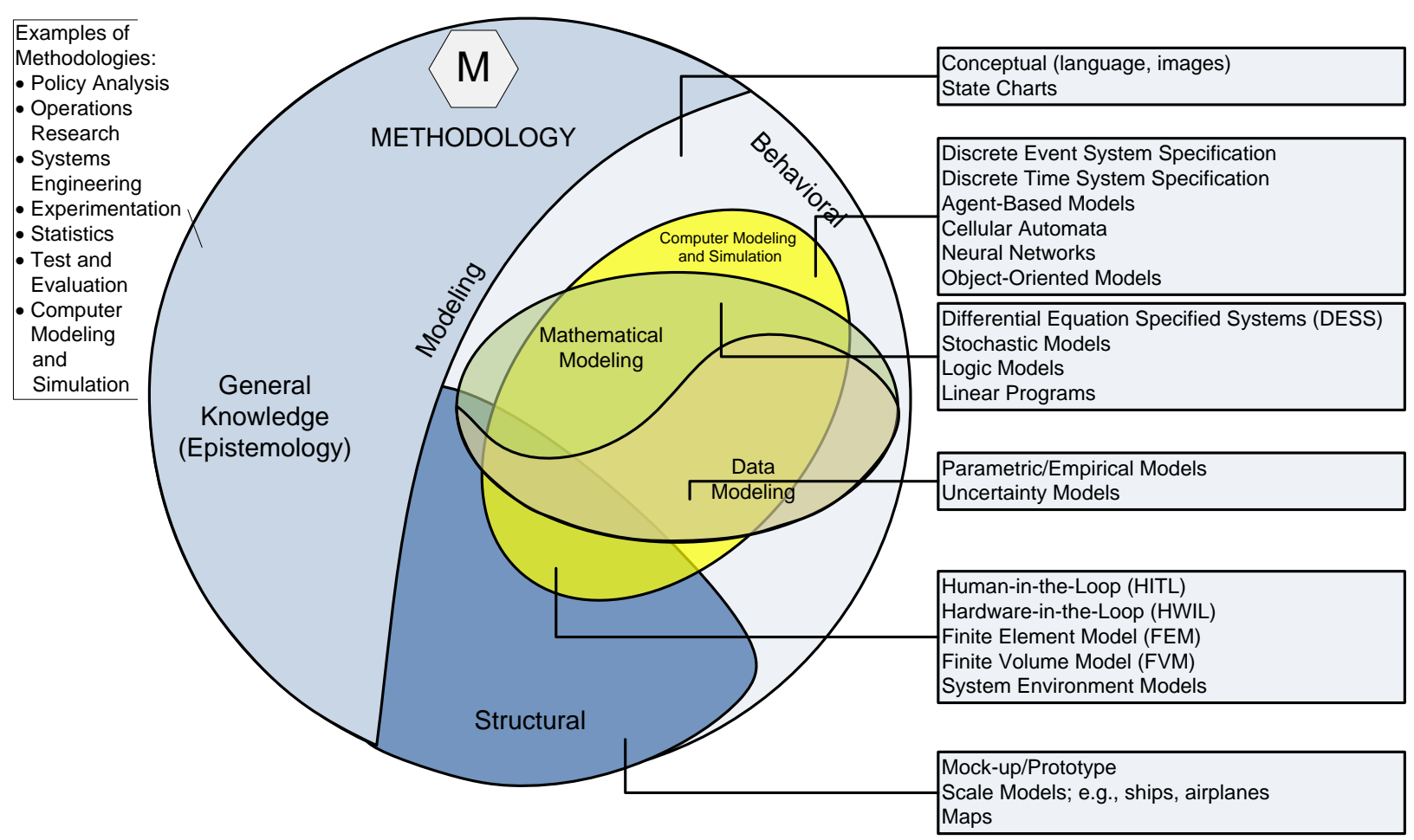

Figure 5: Modeling in methodology

Although M\&S capabilities are tools in many different methodologies, M\&S using computers is itself a methodology with supporting processes, methods and tools. Figure 6 illustrates a simplified, generic process for development of computational M\&S capabilities to address a non-trivial engineering or scientific problem from the perspective of an M\&S developer. The process shown in Figure 6 also maps to the LUMAS model as shown in the figure. This process is also applicable to simpler problems where trivial steps may be combined. Also, the M\&S developer may be the problem solver and consumer of the $M \& S$ results such as an engineer addressing a systems design question or a program manager doing a "what if' analysis to assess the risk to a program.

The first step in the process includes the model or code developer (U) developing a clear understanding of what problem situation (S) the consumer of the M\&S results is trying to address. A conceptual model of the system or problem serves as a framework in developing and implementing the appropriate computer modeling capability (A) using the M\&S methodology (M) to address the question at hand. With a clear conceptual model in mind, developers have a number of choices to make in generating results:

- What data, knowledge, theories, or models are available or applicable to address the problem at hand?

- Is the data, knowledge, or understanding sufficient in both quality and quantity to address the problem at hand, or will additional data or observations be required to support development?

- What is the risk of using erroneous results, e.g., will these results be the only input to a decision, or will other sources of information be available to support decision making?

- How can the conceptual model be expressed mathematically or physically?

- What boundary and initial condition should be used?

- What modeling paradigm or approach would be most appropriate to implement the analysis?

- Given the developers' experience, what particular codes or capabilities would be most suitable for implementing the model, considering software, hardware, and other constraints and limitations?

- Given the code or computer capability has been developed, have any mistakes or errors been made in completing this or in entering the data? 


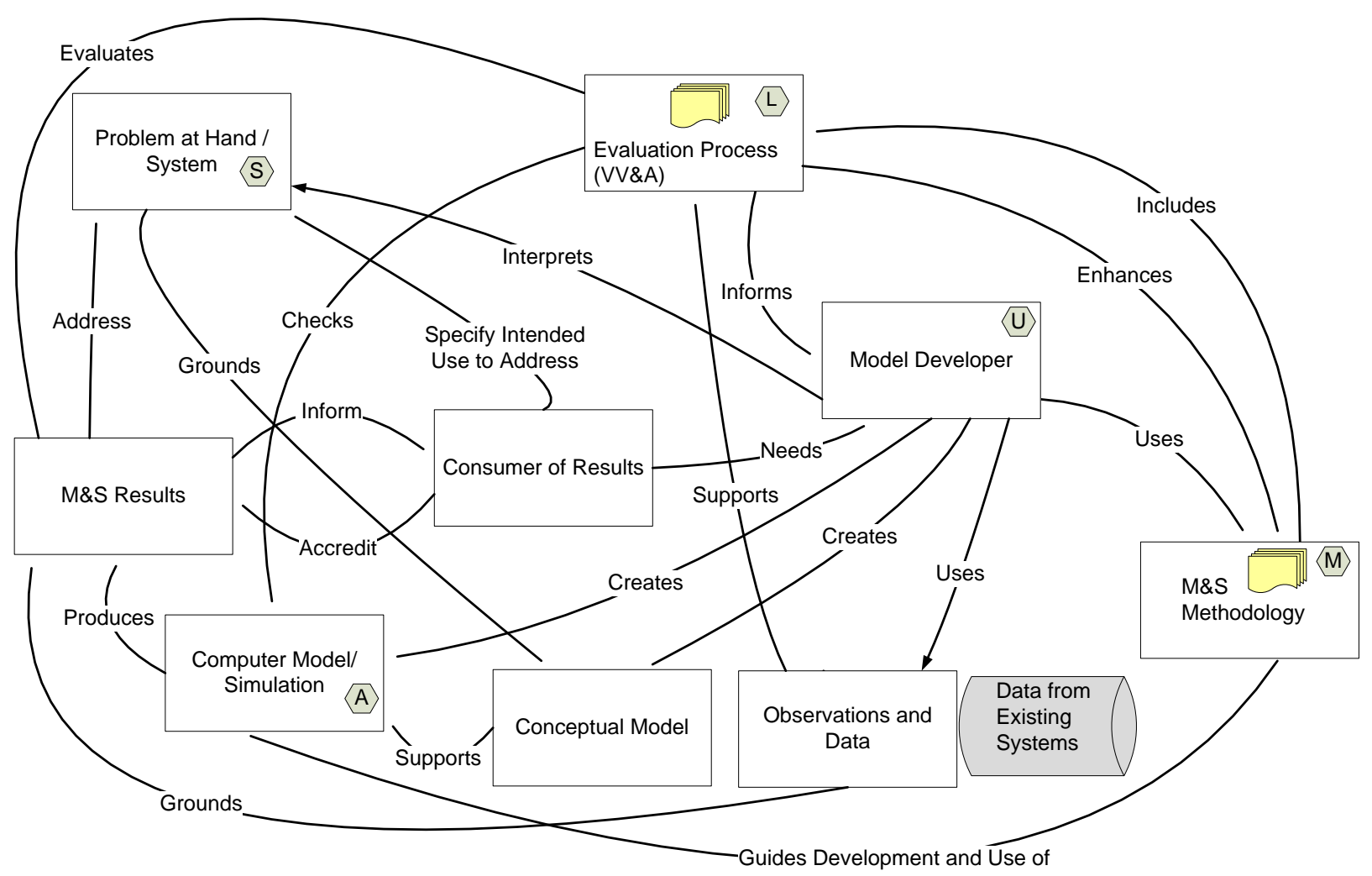

Figure 6: Computer Modeling and Simulation - Developer’s Perspective

- Given there are no mistakes or errors found in developing the capability or entering the data, are the results realistic, and do they make sense?

- What approach should be used to ensure that the results are correct?

- How do uncertainties and approximations affect the computational results?

- Given that everything else is correct, are the results suitable to address the problem at hand?

- How should the results and associated uncertainty be present for use in decision making?

M\&S capabilities are used to model only selected aspects of a system and the models are implemented in a computing environment; therefore, the models need to be critically evaluated to ensure that the results are credible for their specific intended use, and this is typically done using an evaluation process (L) which is included in the M\&S methodology (M) and informs the model developer (U) of the quality of the M\&S capability and results in addressing the problem at hand (S).

Evaluation of M\&S capabilities and results should take into account the many factors that affect the quality of the results including the level of understanding or knowledge of the issues being addressed and the experience level of model developers. Several organizations have developed processes and guidelines to address the credibility of M\&S capabilities. For example, DoD has a process for documentation, evaluation, and certification of M\&S results known as Verification, Validation and Accreditation (VV\&A) that is defined in a recommended practice guide [DoD 2006]. The DoD process is implemented in policy, which develops a common understanding of the major steps in the VV\&A process defined as below [DoD 2009]: 
- Verification. The process of determining that a model implementation and its associated data accurately represents the developer's conceptual description and specifications.

- Validation. The process of determining the degree to which a model and its associated data are an accurate representation of the real world from the perspective of the intended uses of the model.

- Accreditation. The official certification that a model, simulation, or federation of models and simulations and its associated data are acceptable for use for a specific purpose.

All M\&S capabilities should complete verification and validation (V\&V). M\&S capabilities used as the primary input to critical decision making, e.g., on cost, schedule, or performance of the system, should be formally accredited to certify that the results are credible for their intended use. Analysts and decisionmakers need to be aware of these sorts of issues when presented with computational modeling and simulation results.

[Balci 1998] developed a taxonomy and describes the use of different methods to evaluate M\&S capabilities and results based on software testing approaches. Figure 7 identifies these verification, validation, and testing methods or techniques which can be used to support an evaluation process such as VV\&A.

In addition to the use of recommended practices for conceptual modeling and ensuring model credibility, model developers should employ recommended practices for a number of other aspects. [Jain 2011] recommends best practices for modeling, simulation, and analysis for homeland security applications for the following aspects:

1. conceptual modeling

2. innovative approaches

3. software engineering

4. model confidence/ verification, validation and accreditation (VV\&A)

5. use of standards

6. interoperability

7. execution performance

8. user friendliness and accessibility 


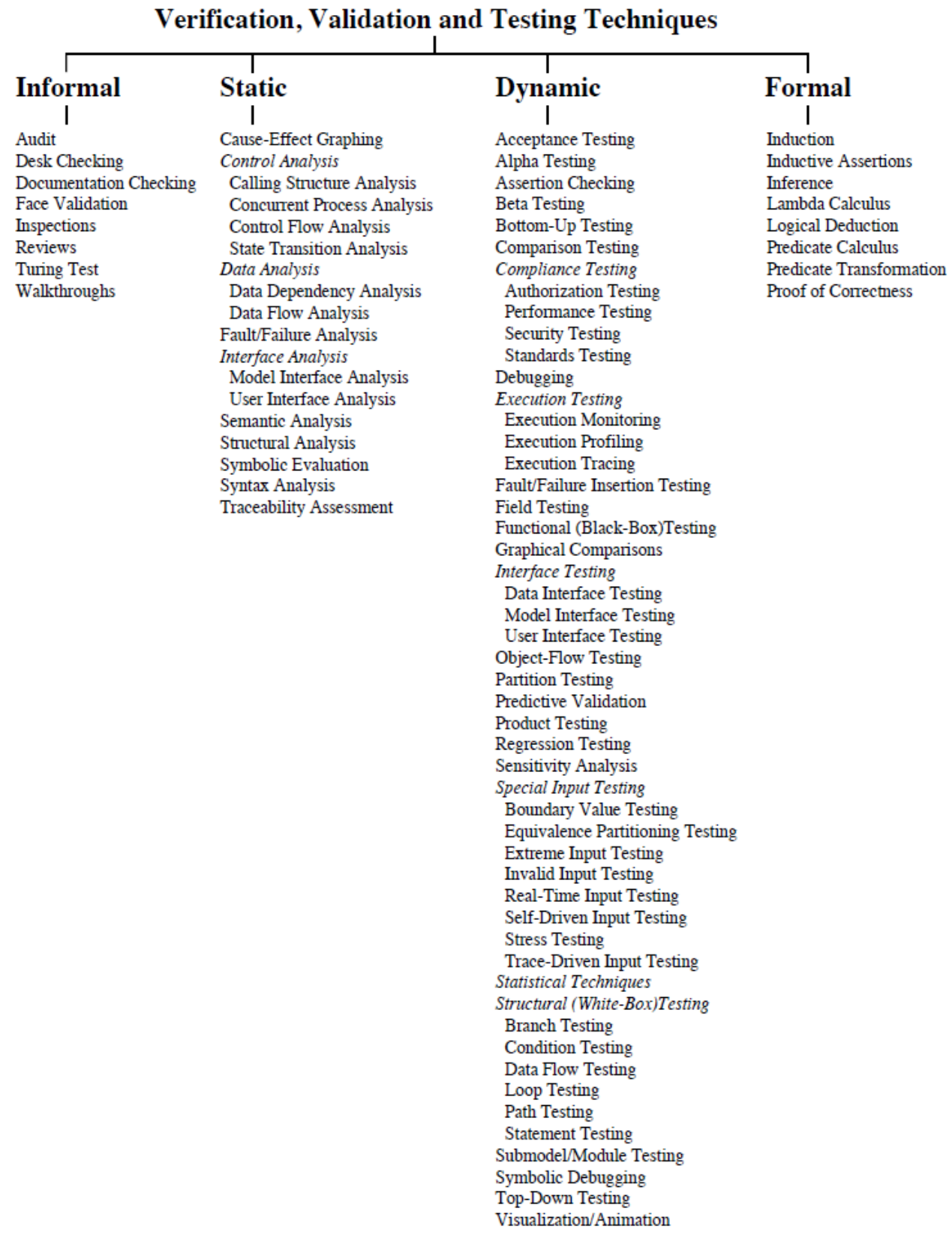

Figure 7: Taxonomy of Verification, Validation, and Testing Techniques (from [Balci 1998])

\section{Needs Analysis Overview}

Modeling and simulation should be used to support the needs of the various CIKR sectors, managers, analysts, service providers, and first responders within the homeland security community. Most importantly, it must support the planning and response needs of the NIPP partners including the Department of Homeland Security and other federal, state, local, tribal, territorial, and private sector organizations. The high level needs identified below have been derived from the National Infrastructure Protection Plan (NIPP) [DHS 2009]. High level needs for CIKR modeling and simulation have been grouped into the following categories: 
- Model, simulation, tool, and database development

- M\&S maintenance, updates, and security

- M\&S partnering and coordination

- M\&S resource support and information dissemination

A list of high level user and customer needs for CIKR M\&S follows:

Model, simulation, tool, and database development -

- Provide modeling, simulation, and analysis of the CIKR assets and systems to enhance preparedness, protection, response, recovery, and mitigation activities.

- Develop, protect, and maintain data systems and simulations to enable continuously refined risk assessment within and across sectors and to ensure preparedness for domestic incident management.

- Use models and simulations to comprehensively examine the potential consequences from terrorist attacks, natural disasters, and manmade accidents that affect CIKR and to analyze sector, cross-sector, and regional dependencies and interdependencies, including the cyber domain.

- Conduct pre-planned, short-term and long-term analyses; as well as unplanned, priority analytical projects that are based on higher-level tasking or that are related to current threats to CIKR (e.g., hurricane CIKR impact analysis).

- Conduct pre-incident studies (e.g., hurricane scenario studies) that are posted and available for downloading on the Homeland Security Information Network (HSIN).

- Work with end-users to design operations-related tools that provide maximum utility and clarity for CIKR protection activities in both emergencies and routine operations.

- Identify and integrate existing databases and other data services into CIKR databases and data systems, such as the Integrated Data Warehouse (IDW), to: reduce the duplication of effort; ensure that available data are consistent, current, and accurate; and provide users with a consolidated picture across all CIKR sectors.

- Facilitate the actual integration of supporting databases or the importation of data into CIKR protection databases and data systems using a common, standardized format, data scheme, and categorization system or taxonomy specified by DHS in coordination with the SSAs.

- Provide guidance on the vetting of modeling tools to include the use of private sector operational, technical, and business expertise.

- Provide mechanisms for accessing and inputting information into models, simulations, tools, and cross-sector interdependency analyses.

- Develop long-term capabilities by maintaining expertise in the development, application of improved processes and analysis tools in support of longer-term DHS projects.

M\&S maintenance, updates, and security -

- Continuously update, maintain, and/or develop new tools and key databases to keep pace with the constantly evolving threat, technology, and business environments to produce reliable projections.

- Protect sensitive information associated with M\&S tools and databases.

- Work with end-users to design appropriate information protection plans for sensitive information used and produced by CIKR protection modeling tools.

- Outline in the sector plans processes for database, data system, and modeling and simulation development and updates.

- Specify the timelines, milestones, and schedules for the initial population of CIKR databases, as well as their regular maintenance and updates.

- Define the schedule for integrating data and databases into such systems as the IDW. 
M\&S partnering and coordination -

- Partner with the private sector on M\&S activities to add value to industry's ability to assess risk and refine its own business continuity and security plans, as well as to contribute to the security and sustained economic vitality of the for CIKR protection and resiliency.

- Develop and maintain simulation and modeling capabilities in coordination with partners that have relevant modeling capabilities to create appropriate mechanisms for the development, maintenance, and use of such for CIKR protection as directed by HSPD-7.

- Review existing private sector modeling initiatives and opportunities for joint ventures to ensure that DHS, the SSAs, and their CIKR partners make the maximum use of applicable private sector modeling capabilities.

- Work with sector partners, as appropriate, to facilitate the collection and protection of accurate information for database, data system, and modeling and simulation use and to enhance abilities to innovate and to provide products, services, and technologies to quickly focus on mission needs.

- Establish robust relationships that are useful for sharing and protecting sensitive information regarding threats, vulnerabilities, countermeasures, and best practices.

- Encourage industry and other partners to participate as early as possible in policy development, initiatives, risk analysis, and the management framework so as to help focus corporate and government planning, resource investment, and NIPP implementation.

- Enable greater information sharing regarding specific threats and hazards enabled by the issuance of security clearances to private sector partners.

- Encourage the leveraged application of preparedness guidelines and self-assessment tools within and across sectors so that risks can be managed more effectively and efficiently from the corporate level down to the individual facility level.

- Coordinate and plan across multiple agencies for those assets and facilities that are considered to be at the greatest risk.

- Participate in national-level and cross-sector training and exercise programs, as well as the National Incident Management System.

- Establish informal networks among private sector partners and between the private sector and the various Federal agencies that can be used for all-hazards planning and response.

- Encourage industry to go beyond efforts already justified by their corporate business needs to assist in broad-scale CIKR protection.

- Coordinate with the DHS Science and Technology Directorate (S\&T) and the SSAs on the specification of requirements for the development, maintenance, and application of research- and operations-related modeling capabilities.

- Create an environment that encourages and supports incentives and recognition for companies to voluntarily adopt widely accepted security practices.

- Work with industry to develop and clearly prioritize key missions and enable the protection and/or restoration of related CIKR.

M\&S resource support and information dissemination -

- Provide the resources necessary to enable cross-sector interdependency studies, exercises, symposiums, training sessions, and computer modeling; and otherwise support business continuity planning.

- Provide information on the availability of relevant modeling and simulation capabilities to SSAs, Federal agencies and departments, and other CIKR partners that have CIKR responsibilities through outreach meetings, training, and exercises with sectors, analysts, and consumers.

- Articulate the benefits of CIKR M\&S to government, private sector partners, e.g., corporate leaders, through the use of public platforms and private communications, both the business and national security benefits of investing in security measures that exceed their business case. 
- Promote understanding of CIKR assets, systems, networks, and facilities, and other capabilities through industry ownership and management of a vast majority of CIKR in most sectors.

- Provide private sector owners and operators with timely, accurate, and useful analysis and information on threats to CIKR.

- Enable time-sensitive information sharing, restoration, and recovery support to CIKR partners and priority CIKR facilities and services during emerging threat and incident management situations.

- Target application of limited resources to the highest risk issues, to include Federal grant funding where appropriate.

- $\quad$ Provide support for M\&S R\&D initiatives that are needed to enhance future CIKR protection efforts.

- Establish and conduct joint R\&D and modeling, simulation, and analysis programs.

- Provide operational support to DHS and other Federal Government entities on an as-needed basis in the form of analysis, simulation, and scenario development.

- Reproduce selected products for widespread dissemination in hard copy, by email or via electronic media.

\section{Requirements Specifications}

This section translates the high level needs discussed in the previous section to a set of requirements. The requirements are intended to be common across all the CIKR and hence at a high level. These requirements will serve as the starting set that may need to be enhanced for specific CIKR for unique intended use. A separate document with a more detailed set of common requirements is being developed in a related effort.

\subsection{Intended Use}

CIKR models and simulations will be used by analysts, CIKR managers, emergency planners, first responders, and training personnel to:

a) Analyze the resource requirements, behavior, and performance of CIKR systems

b) Determine the readiness of CIKR systems to respond to various types of emergencies

c) Analyze interdependencies between CIKR systems

d) Model past incidents and system failures for education, training, and analysis purposes

e) Evaluate security measures and practices developed for CIKR systems

f) Conduct training exercises, drills, emergencies, tests, alerts, real world incidents, and planning for national security events

\subsection{Functional Requirements}

This section identifies possible functions that may be included in CIKR models and simulations.

a) Create and evaluate models/computer simulations that provide more information about interdependencies, and promote rapid response, repair, and recovery from attacks

b) Simulate incidents requiring a response based on policies and procedures established for the entity involved

c) Predict the impact of vulnerabilities and protective measures

d) Create simulations and tabletop exercises for national-level multi-agency events

e) Conduct tabletop exercises that simulate real-world security emergency in order to assess and improve the emergency response and preparedness of owners and operators, State and local law enforcement, and local emergency responders

f) Simulate response to catastrophic incidents 
g) Simulate threats, identify vulnerabilities in CIKR systems, measure potential impacts, and evaluate countermeasure, mitigation, and response strategies

h) Perform cross-sector interdependency analyses

i) Test facilities protective measures using trained teams of simulated adversaries to help asset owners and operators determine the effectiveness of their protection programs and prepare staff to respond quickly and properly in the event of an actual incident

j) Establish capabilities for modeling and simulation of strategies for quickly evacuating large crowds (e.g., 50 000-130 000 individuals)

k) Develop modeling and simulation methods to determine the resilience of the sector when an event or incident occurs

l) Create multi-use tools that supports situational awareness, command and control operations, planning, simulations, research, training, and re-analysis of past events

m) Conduct cyber-security assessments of control systems and related technologies

n) Develop advanced control system technologies using modeling and simulation to better evaluate risk

o) Develop and participate in threat simulations and exercises, including those that test cyber-security readiness and response capabilities

p) Use system studies, models, simulations, and analyses to identify, develop, and submit gaps that represent mission needs

q) Provide simulations to train security personnel to secure facilities against a potential attack and handle the aftermath of an attack

r) Provide simulation capabilities for modeling, simulation, and visualization of the Internet as it relates to each CIKR sector

s) Setup more realistic simulations of failure scenarios and the consequences of full or partial failure of CIKR systems

t) Provide capabilities to model chains-of-events, transactions, etc. that lead to CIKR system failures

u) Provide software resources including the tools, models, and communications databases needed to assess network performance, perform modeling and simulation, and visualize network topologies as they relate to CIKR systems

v) Provide capabilities for dependency identification and its utility with other sectors for their own risk analysis and management efforts

w) Support broader national-level interdependency analyses conducted by enhancing the modeling and simulation capabilities of national laboratories and government agencies

$\mathrm{x}$ ) Provide functions to create high level models of CIKR evolutions over time to support analysis of system vulnerabilities, security, readiness, performance and resource requirements

y) Provide training and exercise simulations for CIKR systems that provide functionality for various incident and exercise parameters, exercise control, and after action reviews

z) Provide various types of training implementations including tabletop exercises, 2D and 3D computer gaming, and immersive virtual reality environments

aa) Provide capabilities to refine simulations based on actual incident data, field measurements, and sensor data

bb) Support vector and raster representations of geography, buildings, and other CIKR structures and systems

cc) Support a range of different grid resolutions on critical infrastructure models, maps, and displays, e.g., 30 meter, 100 meter, 1 kilometer, 10 kilometer

dd) Support the integration and/or distributed execution of interrelated CIKR and other models including hazardous material release exposure and effects, incident management systems, healthcare systems, weather, and watershed flows

ee) Identify regions where the exposed population will experience life threatening, serious long-lasting or notable effects from incidents or failure of CIKR systems 


\subsection{Data Requirements}

This section identifies data management issues as well as input and output data types that may be supported for CIKR models and simulations.

a) Establish a data taxonomy, meta-data framework, and detailed information models for CIKR simulation and modeling data to help support analyses and support data interoperability and data/information fusion

b) Establish standard data structures, databases, and exchange mechanisms for CIKR data used in models and simulations

c) Establish a CIKR M\&S data warehouse that categorizes each item in a data item into non-overlapping region to support filtering, grouping, and labeling

d) Establish processes to ensure data quality and provide traceability mechanisms to track data back to original sources

e) Establish an information assurance program to manage risks related to the use, processing, storage, and transmission of information or data and the systems and processes used for those purposes

f) Provide information assurance measures that protect and defend information and information systems by ensuring their availability, integrity, authentication, confidentiality, and non-repudiation of CIKR M\&S data

g) Support the Protected Critical Infrastructure Information (PCII) Program that enhances information sharing between the private sector and the government in order to analyze and secure critical infrastructure and protected systems, identify vulnerabilities and develop risk assessments, and enhance recovery preparedness measures

h) Use geographical information systems-based methods to track and model the effects of incidents on CIKR systems, e.g., the flow and concentration of contaminants in source water supplies

i) Establish a data taxonomy, information models, databases, and exchange mechanisms for CIKR data including:

- Structure and layout of CIKR systems and support organizations

- CIKR system data flows

- Inventory of CIKR resources

- Standard CIKR management operations, processes and procedures

- Message logs and incident time lines

- Specification of the incident area including event types and parameters, timing of events, schedule of restoration activities, terrain and buildings in affected areas

- Demographics data: population location, density, and attributes by time of day

- Meteorological data: observed and forecast weather conditions that may affect an incident including wind speed, direction, and precipitation

- $\quad$ Plume data for hazardous material releases and explosions

j) Support of appropriate existing data standards in model implementations, training and exercise simulations, e.g., SCORM - Shareable Content Object Reference Model [ADL 2011].

\subsection{User Interface Requirements}

This section identifies user interface capabilities that may be supported for CIKR models and simulations.

a) Provide three-dimensional urban imagery with data visualization, zoom capabilities, and high-spatial resolution

b) Provide after-action reporting capabilities to identify weaknesses and issues identified from exercises, assign offices to be responsible for correcting problems, and track these assignments to ensure completion 
c) Provide tools for modeling, simulation, and visualization of information technology systems

d) Provide capabilities to configure simulation runs with specific CIKR systems, incident types and associated parameters, affected populations, responder resources, weather conditions, and geographic regions

e) Generate graphical views of CIKR systems, failures, incident and responder activities over a 2D or $3 \mathrm{D}$ representation of area of interest at different levels of resolution

f) Provide user control mechanisms that affect rapid execution/playback of simulation runs to move forward and back to desired points in time

g) Use various DHS standard symbology, maps, and representation schemes to display incident parameters, resource locations, and time lines

h) Provide virtual reality interfaces to support 3D gaming for critical infrastructure exercises

i) Provide exercise controller interfaces for the initiation, execution, as well as playback of exercise simulations for after action reviews and hot washes

j) Provide interfaces to generate still image and video files that can be used to transfer results for viewing or playback using other software tools

k) Provide displays that help users understand the uncertainty associated with M\&S results

\subsection{Performance Requirements}

This section identifies possible performance considerations for CIKR models and simulations.

a) Support various simulation techniques, as appropriate such as system dynamics modeling, discrete event simulation, business process modeling, agent-based modeling, and computational fluid dynamics models as appropriate to create specific individual-based computational models for modeling complex systems, emergence, Monte Carlo Methods, computational sociology, multi-agent systems, and evolutionary programming

b) Support time scaling of models and simulations and abilities to move forward rapidly in time to focus on events of interest (real-time for training and faster than real-time to support planning and analysis during actual incidents)

c) Provide for updates from real time CIKR system information, meteorological databases and observations

d) Share model predictions with other software applications

e) Provide capabilities for interoperable networked implementations at different sites by different organizations

\subsection{Credibility and Evaluation Requirements}

This section identifies considerations for ensuring the credibility and evaluating CIKR models and simulations.

a) Support the Systems-Based Risk Management (SBRM) process

b) Establish cross-sector working groups to support the development and evaluation of simulation models

c) Support evaluation of M\&S tools using standard validated scenarios with data and results

d) Support evaluation of M\&S tools through identification of standard processes and techniques for the purpose that may be customized to CIKR sectors if needed

e) Establishing procedures for evaluating credibility of CIKR and other data used as input for M\&S tools

f) Provide guidance for generating uncertainty data with results from M\&S tools 


\section{Identification of $M \& S$ Resources}

This section identifies existing M\&S resources that support CIKR and are possibly relevant to meeting some of the needs and requirements presented in sections 4 and 5 . Resources that primarily support other M\&S areas or domains, e.g., incident command, are not included.

The section is divided into:

- $\quad$ Projects, facilities, and capabilities (Section 6.1)

- Simulation models and tools (Section 6.2)

- Relevant Standards and Guidelines (Section 6.3)

- Data Sources (Section 6.4)

\subsection{Projects, Facilities, and Capabilities}

A number of projects have been initiated to address CIKR M\&S issues. Although some have been sponsored by DHS, there have been others conducted by outside organizations both within and outside of the U.S. A representative list of projects follows:

Canada's Public Security Technical Program CIP Projects: The modeling and simulation (M\&S) of elements of Canada's critical infrastructure — and particularly the area of dependencies and interdependencies between sectors and sub-sectors-is developing as a unique, horizontal CI research area with opportunities to support all CI sectors. Two ongoing projects are: PSTP Study 08-0120CI (2009 to 2010) - Conducting a HAZMAT scenario-based live simulation of telecommunication CI business continuity capability that will include the development and validation of "as-is" and "to-be” models (using an established architecture framework); PSTP Study 08-100CI (2009 to 2010) -Integrated Evaluation of Critical Infrastructure Interdependencies for Major Event Planning, using M\&S technologies [DRDC 2009].

Chemical Sector Supply Chain and Economics Project: This project is a key component of a larger effort to deliver Enabling Homeland Security Capabilities (EHCs) for the Modeling, Mapping, and Simulation program. The first goal of this project is to populate a detailed data set of the chemical and petrochemical manufacturing, supply and distribution components that comprise the chemical infrastructure supply chain. The second goal is to develop a means to mathematically analyze not only the consequence of significant threats, but also the resiliency of the supply chain to recover from these impacts [DHS 2011a].

Critical Infrastructure Test Range Complex (CITRC): CITRC at Idaho National Laboratory is a national, comprehensive program that researches, develops, and tests technologies, systems, and policies to protect the nation's infrastructure. CITRC is comprised of the sites formerly occupied by the Auxiliary (originally Army) Reactor Area (ARA) and the Power Burst Facility (PBF), later part of the Waste Reduction Operations Complex (WROC). The remainder of INL land not occupied by facilities is designated part of the site-wide critical infrastructure test range (CITR), and serves as a real-world natural laboratory. CITR has industrial-scale infrastructure components, including an isolatable full-scale electric power grid with a 61-mile transmission loop, seven independent substations, and a control room for conducting comprehensive interoperability, vulnerability and risk assessments [INL 2008].

Design of an Interoperable European federated Simulation network for critical InfraStructures (DIESIS): This project proposes to establish the basis for a European modeling and simulation e-Infrastructure based upon open standards to foster and support research on all aspects of critical infrastructures with a specific focus on their protection. This European e-Infrastructure will support full cooperation of the different 
partners in charge for studying (inter)dependencies of critical infrastructures, while preserving the confidentiality of the proprietary knowledge embedded into the different models and simulation packages. The project aims to address the following: availability of models and data for single infrastructures, interoperable simulation of multiple infrastructures, and testbeds and benchmarks for protection solutions [DIESIS 2011].

Group Model Building for Critical Infrastructure Simulation: A group of researchers from Europe and the U.S. are utilizing group model building workshops to develop systems dynamics models of critical infrastructure. In initial reported effort Group Model Building (GMB) and system dynamics were used to develop plausible scenarios for a CI \& Information Technology (IT) crisis with cross-border effects. Expert consensus was achieved about the crisis causal structure "driving" the event into a cross-border crisis. The model showed the negative effects of uncoordinated single country action on crisis perception and resource misallocation, in turn escalating crisis duration and severity. It is particularly severe if the crisis is exacerbated by IT failures [Sveen 2010].

Modeling Delay Tolerant Networking following Communication Infrastructure Disruption in a Disaster: Delay Tolerant Networking (DTN) is needed for communications following disruptions in communications infrastructure in a disaster. In a disaster scenario people with hand-held wireless devices (e.g., cell phone, PDA, even laptops), houses with WiFi routers and automobiles with radios can be connected in an effective way using DTN devices to form a functional communication network. This project is developing a mobility model that includes the impact of the disaster on the transportation network, and that models population and relief vehicle movement. The researchers are augmenting the “Opportunistic Network Environment” (ONE) simulator of DTNs with required extensions for the purpose [Uddin 2009].

National Infrastructure Simulation and Analysis Center (NISAC): NISAC is a modeling, simulation, and analysis program within DHS comprising personnel in the Washington, D.C., area as well as from Sandia National Laboratories (Sandia) and Los Alamos National Laboratory (LANL). A facility dedicated to NISAC is located at Sandia Albuquerque. Congress mandated that NISAC serve as a "source of national expertise to address critical infrastructure protection" research and analysis. NISAC prepares and shares analyses of critical infrastructure and key resources (CIKR), including their interdependencies, vulnerabilities, consequences, and other complexities. Its mission is to improve the robustness of the nation's critical infrastructures by providing an advanced modeling and simulation capability that will enable an understanding of how the infrastructure operates; help identify vulnerabilities; determine the consequences of infrastructure outages; and optimize protection and mitigation strategies. NISAC's objectives are to leverage the existing capabilities of the NISAC partners to provide leadership in critical infrastructure interdependencies modeling, simulation, and analysis [NISAC 2011a].

Particle Dynamic Simulation for Critical Infrastructure Protection: The project utilizes particle modeling for the simulation of dynamic fracture phenomena in homogeneous and heterogeneous materials such as encountered in blasts on a concrete wall. Particle modeling is a dynamic simulation method that typically uses a lattice of small (but not molecular level) particles, evolving according to laws of mechanics, as a discrete representation of fluids and/or solids. The analysis will be used to establish design requirements for nanoparticle reinforcement of concrete structural components to meet severe loading (i.e., blast and seismic) demands [SERRI 2007].

Virtual USA - A DHS program, called Virtual USA, will enable first responders nationwide to link disparate tools and technologies in order to share the location and status of critical assets and information. These may include power and water lines, flood detectors, helicopter-capable landing sites, emergency vehicle and ambulance locations, weather and traffic conditions, evacuation routes, and school and government building floor plans [Boyd 2009]. 


\subsection{Simulations, Models and Tools}

A large number of critical infrastructure modeling tools have been developed through the efforts of federal agencies, universities, research organizations and commercial companies. A survey performed by Idaho National Lab under the sponsorship of U.S. Technical Support Working Group identified 30 tools for critical infrastructure interdependency modeling [Pederson 2006]. This section lists existing tools that have been identified through Internet searches and site visits to organizations involved in M\&S of CIKR systems. The tools are arranged alphabetically based on their developer's acronyms, or in some cases, abbreviations assigned by the authors for purposes of the readability of this document.

\begin{tabular}{|c|c|}
\hline Tool Acronym & Brief Description \\
\hline AIMS & $\begin{array}{l}\text { The AIMS system is designed to aid research into critical infrastructures and the } \\
\text { interdependencies between them. The simulation suite focuses on the types of } \\
\text { services that are provided by infrastructure components. Each infrastructure system } \\
\text { component is modeled as an agent and its services as its behavior [Bagheri 2007]. }\end{array}$ \\
\hline AIMSUN & $\begin{array}{l}\text { Developed by Transport Simulation Systems, Spain, AIMSUN provides integrated } \\
\text { modeling of traffic at macro-meso-micro scales. It provides advanced traffic models } \\
\text { capable of fast execution [TSS 2010]. It is one of the tools used in the M\&S } \\
\text { Integration Framework project at the National Center for the Study of Preparedness } \\
\text { and Catastrophic Event Response (PACER) located at Johns Hopkins University. }\end{array}$ \\
\hline ATFP & $\begin{array}{l}\text { Anti Terrorism/ Force Protection (ATFP) tool has been developed at the Naval } \\
\text { Postgraduate School and can be used for planning for waterside security for ships in a } \\
\text { port. It combines agent-based simulation with X3D based visualization. The target } \\
\text { users are personnel in charge of port security and Coast Guard [Brutzman 2006]. }\end{array}$ \\
\hline ATOM & $\begin{array}{l}\text { Air Transportation Optimization Model (ATOM) is a network flow model of the air } \\
\text { transportation system of the nation. It can be used to determine the impact of } \\
\text { disruptions and to develop optimal re-routing schemes [NISAC 2011b]. }\end{array}$ \\
\hline CARVER2 & $\begin{array}{l}\text { The CARVER2 vulnerability assessment tool is designed to quickly and easily } \\
\text { identify and compare potential natural disaster and/or terrorist targets at the local, } \\
\text { state and national levels in order to assist government officials in the allocation of } \\
\text { protective resources. It does not have any simulation capability. Developed under the } \\
\text { sponsorship of the National Institute of Standards and Technology, it is available free } \\
\text { of charge to federal, state, and local government officials and agencies [NI2CIE } \\
\text { 2009]. }\end{array}$ \\
\hline CASCADE & $\begin{array}{l}\text { The CASCADE model can be used for analyzing the potential of catastrophic } \\
\text { disruptions of large, interconnected infrastructure systems due to cascading failures. It } \\
\text { is a probabilistic model of load depending cascading failure. It has been extended to } \\
\text { include a dynamic component. It can be used to evaluate the impact of policies on the } \\
\text { reliability of infrastructure for various operation ranges [Carreras 2009]. }\end{array}$ \\
\hline$C I^{3}$ & $\begin{array}{l}\text { Critical Infrastructure Interdependencies Integrator }\left(\mathrm{CI}^{3}\right) \text { has been developed at } \\
\text { Argonne National Labs to estimate (through Monte Carlo simulation) the time and/or } \\
\text { cost to restore a given infrastructure component, a specific infrastructure system, or an } \\
\text { interdependent set of infrastructures to an operational state. } \mathrm{CI}^{3} \text { also provides a } \\
\text { framework for incorporating uncertainty into the analysis of critical infrastructures }\end{array}$ \\
\hline
\end{tabular}




\begin{tabular}{|c|c|}
\hline & [Gillette 2002]. \\
\hline CIMS & $\begin{array}{l}\text { Critical Infrastructure Modeling System (CIMS) has been developed to examine the } \\
\text { interrelationships between infrastructure networks and more specifically, the } \\
\text { emergent systems behaviors that develop when one or more nodes within the system } \\
\text { are perturbed. It takes a command-level approach seeking to provide decision makers } \\
\text { with sufficient information in terms of mission [Dudenhoeffer 2006]. }\end{array}$ \\
\hline CIMSuite & $\begin{array}{l}\text { Critical Infrastructure Modeling (CIMSuite) software offers powerful, easy-to-use } \\
\text { tools for both modeling and simulating complex interactions of infrastructure systems } \\
\text { and predicting emergent behaviors through time. CIMSuite software gives users the } \\
\text { potential to integrate multiple systems and visualize the results of cascading events } \\
\text { including factors such as human social dynamics. The CIMSuite software data } \\
\text { structure lends itself to both 3-D visualization and further algorithmic treatment, } \\
\text { including time-step simulations, real-time data integration and analysis using methods } \\
\text { such as genetic algorithms and neural networks [INL 2007]. }\end{array}$ \\
\hline CIPDSS & $\begin{array}{l}\text { Critical Infrastructure Protection Decision Support System (CIPDSS) has been } \\
\text { developed jointly by LANL, Sandia and Argonne National Labs (ANL). The set of } \\
\text { tools under the CIPDSS program models the impact of CI on the economy, } \\
\text { government, and population. LANL developed the city level models, Sandia } \\
\text { developed the national level models while ANL provided the decision support part. } \\
\text { The set of tools is intended to provide "orders of magnitude" results quickly. It was } \\
\text { used for the analysis underlying NISAC's report on potential impact of pandemic } \\
\text { influenza [Powell 2007]. }\end{array}$ \\
\hline CIPDSS-DM & $\begin{array}{l}\text { CIPDSS-DM is a model used to compute the relative preference of alternative } \\
\text { intervention strategies based on multi-attribute decision theory and was developed } \\
\text { specifically as an aid to making decisions under conditions of uncertainty and risk. It } \\
\text { helps decision makers integrate the large amount of quantitative information and } \\
\text { insights generated by consequence simulations into a single measure of relative merit } \\
\text { that informs the decision maker's comparison of available alternative intervention } \\
\text { strategies. The relative preference model is combined with an analysis model that } \\
\text { calculates the level of confidence in choosing any one intervention strategy over } \\
\text { another and quantifies maximum and expected levels of satisfaction and regret } \\
\text { [NISAC 2007]. }\end{array}$ \\
\hline CIPMA & $\begin{array}{l}\text { The Critical Infrastructure Protection (CIP) Modeling and Analysis (CIPMA) } \\
\text { Program is a key component of the Australian Government's efforts to enhance the } \\
\text { protection of the critical infrastructure. The capability includes a series of 'impact } \\
\text { models' to analyze the effects of a disruption to critical infrastructure services. This } \\
\text { information is assisting the development and direction of government policy in } \\
\text { national security and critical infrastructure protection (CIP), and helping owners and } \\
\text { operators to better protect their critical infrastructure [TISN 2010]. }\end{array}$ \\
\hline CIPR/Sim & $\begin{array}{l}\text { Critical Infrastructure Protection and Resiliency Simulator (CIPR/sim) allows } \\
\text { emergency planners to visualize the real-time cascading effects of multiple } \\
\text { infrastructure failures before an actual emergency occurs. It uses a common operating } \\
\text { framework that allows the tool to import real-time data from numerous existing } \\
\text { analysis modules, including RTDS (Real Time Digital Simulator) for electric grid }\end{array}$ \\
\hline
\end{tabular}




\begin{tabular}{|c|c|}
\hline & $\begin{array}{l}\text { analysis, QualNet for telecommunications analysis, and PC Tide for wind speed and } \\
\text { flood surge analysis [Walsh 2009]. }\end{array}$ \\
\hline CISIA & $\begin{array}{l}\text { Critical Infrastructure Simulation by Interdependent Agents (CISIA) is a simulator } \\
\text { that uses a modular and sufficiently abstract representation of the different } \\
\text { infrastructures' components to allow consistent descriptions, starting from the } \\
\text { incomplete and generic data acquirable from stakeholders. Each component interacts } \\
\text { with the others via a multitude of mechanisms that codify different concepts of } \\
\text { proximity. The simulator has been used to analyze, in a simplified scenario, crisis } \\
\text { evolution in the urban area of Rome in the presence of a failure in the electric power } \\
\text { system [De Porcellinis 2008]. }\end{array}$ \\
\hline CommAspen & $\begin{array}{l}\text { CommAspen is an agent-based model for simulating the interdependent effects of } \\
\text { market decisions and disruptions in the telecommunications infrastructure on other } \\
\text { critical infrastructures in the U.S. economy such as banking and finance, and electric } \\
\text { power. CommAspen extends and modifies the capabilities of Aspen-EE, an agent- } \\
\text { based model previously developed by Sandia National Laboratories to analyze the } \\
\text { interdependencies between the electric power system and other critical infrastructures } \\
\text { [Barton 2004]. }\end{array}$ \\
\hline$D E M$ & $\begin{array}{l}\text { The Discrete Event Model (DEM) has been combined with hydraulic simulation } \\
\text { model (Adaptive Hydraulic model [ADH]) to produce an integrated set of tools for } \\
\text { addressing a wide range of navigation and operational problems at Corps locks and } \\
\text { dams and commercial facilities and thus investigate issues with waterways } \\
\text { transportation infrastructure [USACE 2011]. }\end{array}$ \\
\hline$D E W$ & $\begin{array}{l}\text { Distributed Engineering Workstation (DEW) can be used to create integrated system } \\
\text { models, incorporating entire power distribution network from substations to service } \\
\text { points. It supports interconnected, multidisciplinary models (i.e. Power, Fluid, Gas) } \\
\text { and system interdependencies and provides analytical tools for advanced system } \\
\text { planning, design, and operation [EDD 2011]. }\end{array}$ \\
\hline DYNA3D & $\begin{array}{l}\text { DYNA3D ("Dynamics in } 3 \text { Dimensions") is an explicit finite-element code that } \\
\text { addresses the behavior of structures as they deform and fail. Homeland security } \\
\text { applications of the code include: blast-effect analyses, mass transit vulnerability } \\
\text { analysis (underwater tunnel), blast resistant trash can analysis, and analysis of effects } \\
\text { of destructive earthquakes and major accidents on bridges and dams. Some of the } \\
\text { analyses include use of related codes such as ALE3D (Arbitrary Lagrangian Eulerian } \\
\text { in 3D code for modeling explosive processes), NIKE3D (Nonlinear implicit 3D finite } \\
\text { element code for modeling dynamic deformations) and SPH (Smooth Particle } \\
\text { Hydrodynamics code for modeling a hole in an underwater tunnel) [LLNL 2011]. }\end{array}$ \\
\hline EMCAS & $\begin{array}{l}\text { The Electricity Market Complex Adaptive System (EMCAS) models the electricity } \\
\text { market representing its diverse participants as "agents." All agents have their own set } \\
\text { of objectives, decision-making rules, and behavioral patterns. Further, agents can } \\
\text { draw on an array of historical information (e.g., past power prices) and projected data } \\
\text { (e.g., next-day load) to support their unique decision process. EMCAS has been used } \\
\text { to study electricity market restructuring issues in the U.S., Europe, and Asia [ANL } \\
\text { 2011a]. }\end{array}$ \\
\hline
\end{tabular}




\begin{tabular}{|c|c|}
\hline FAIT & $\begin{array}{l}\text { Fast Analysis Infrastructure Tool (FAIT) is used to determine the significance and } \\
\text { interdependencies associated with elements of the nation's critical infrastructure. It } \\
\text { utilizes system expert-defined object-oriented interdependencies, encoded in a rule- } \\
\text { based expert systems software language (JESS), to define relationships between assets } \\
\text { across different infrastructures. These interdependencies take into account proximity, } \\
\text { known service boundaries, ownership, and other unique characteristics of assets found } \\
\text { in their associated metadata [NISAC 2011c]. }\end{array}$ \\
\hline FEPVA & $\begin{array}{l}\text { The Framework for Electricity Production Vulnerability Assessment (FEPVA) can be } \\
\text { used to assess the potential impact of natural disasters or malicious attacks for both } \\
\text { response and preventative purposes. In particular, it can be used to identify the power } \\
\text { plants that will be potentially affected and to what degree given a disruption of fuel } \\
\text { supply due to a disaster. The framework has three major capabilities: (1) requirement } \\
\text { analysis, data acquisition, and data processing; (2) development of the data } \\
\text { warehouse; and (3) visualization and data mining [Shih 2009]. }\end{array}$ \\
\hline FinSim & $\begin{array}{l}\text { Financial System Infrastructure Model (FinSim) represents the U.S. financial services } \\
\text { sector as a complex decentralized system with multiple interacting autonomous } \\
\text { decision nodes, or agents. Those nodes represent different types of real-world agents, } \\
\text { such as banks, traders, markets, and brokers. The financial system interactions are } \\
\text { executed through an explicit message exchange, intermediated by the } \\
\text { telecommunications system with electric power dependencies for the purpose of } \\
\text { investigating possible vulnerabilities [Outkin 2006]. }\end{array}$ \\
\hline Fort Future VI & $\begin{array}{l}\text { Fort Future Virtual Installation (VI) is meant for installation level infrastructure } \\
\text { modeling. It integrates utility system simulations with each other and with a resource } \\
\text { contention process model. Results from utility simulations include detailed operating } \\
\text { data, such as flow rates and pressures in water systems and voltages and currents in } \\
\text { electrical systems. The VI incorporates rules of thumb (heuristics) to translate } \\
\text { simulation results into actionable information based on the question at hand [USACE } \\
\text { 2010]. }\end{array}$ \\
\hline FRAM & $\begin{array}{l}\text { The Fuzzy Relation Analysis Method (FRAM) method has been implemented in GIS } \\
\text { for modeling and analyzing interdependencies of critical infrastructures. The } \\
\text { modeling processes include the following four components: (1) an asymmetrical } \\
\text { fuzzy relation matrix representing direct relationships between nodes in infrastructure } \\
\text { networks; (2) an asymmetrical fuzzy relation matrix representing direct and cascade } \\
\text { relationships between infrastructure networks; (3) a mathematical transformation } \\
\text { converting asymmetric relations in to transitive relations with properties of direct } \\
\text { relations stronger than indirect relations; and (4) a method for ranking infrastructures } \\
\text { in terms of their relative importance [Cheng 2007]. }\end{array}$ \\
\hline I2SIM & $\begin{array}{l}\text { Infrastructure Interdependencies Simulation (I2SIM) is being developed under the } \\
\text { Joint Infrastructure Interdependencies Research Program (JIRP) at the University of } \\
\text { British Columbia in Canada. It is intended to capture the complex time line dynamics } \\
\text { that occur in a system of multiple infrastructures as events develop during large } \\
\text { disaster situations. The system modeling and solution approach implemented in } \\
\text { I2SIM is based on a dynamic time-sensitive coordination of the delivery of the vital } \\
\text { goods and services required to maximize human survivability. I2SIM models the } \\
\text { network of networks that results when multiple CIs are brought into the picture }\end{array}$ \\
\hline
\end{tabular}




\begin{tabular}{|c|c|}
\hline & simultaneously [UBC 2007]. \\
\hline IEISS & $\begin{array}{l}\text { Interdependent Environment for Infrastructure System Simulations (IEISS) is a } \\
\text { flexible and extendible software framework designed for MS\&A of multiple } \\
\text { interdependent infrastructures. It allows study of complex, nonlinear and emergent } \\
\text { system behaviors through a system-of-systems modeling approach and a unified view } \\
\text { of physical interdependencies. It includes the following infrastructure models: } \\
\text { electric power, natural gas, water, petroleum (POL), telecomm and SCADA. It } \\
\text { includes interactive 2D and 3D visualizers. It is accessible through HYDRA, a } \\
\text { service oriented architecture, and INDRA, a browser enabled client for risk based } \\
\text { decision support [NISAC 2011d]. }\end{array}$ \\
\hline IIM & $\begin{array}{l}\text { Inoperability Input-Output Model (IIM) estimates the cascading inoperability and } \\
\text { economic losses that result from interdependencies within large-scale economic and } \\
\text { infrastructure systems. Based on the Nobel Prize-winning W. Leontief economic } \\
\text { model, the IIM is a computationally efficient, inexpensive, holistic method for } \\
\text { estimating economic impacts. It can be used to calculate higher-order effects from } \\
\text { attacks to vulnerabilities and implementation of risk management policies in large- } \\
\text { scale economic systems and to evaluate risk management options against multiple } \\
\text { objectives [Crowther 2005]. }\end{array}$ \\
\hline $\begin{array}{l}\text { INTEPOINT } \\
V U\end{array}$ & $\begin{array}{l}\text { IntePoint Vu uses a combination of techniques to analyze complex environments and } \\
\text { model system-wide interdependencies across physical, virtual and social networks. It } \\
\text { utilizes Agent-Based Simulation to model the behavior of dynamic systems. It allows } \\
\text { developing a broad understanding of an incident and its implications and facilitates } \\
\text { effective, timely decisions to plan for the unknown [IntePoint 2008]. }\end{array}$ \\
\hline Loki Toolkit & $\begin{array}{l}\text { Loki is a generalized networked-agent modeling toolkit. It includes a set of } \\
\text { components that can be selected, customized, and combined to create abstract models } \\
\text { of diverse networks including power systems, pipelines, social networks, and } \\
\text { financial networks. The ability to combine networks allows modeling the interactions } \\
\text { across these networks. The toolkit includes analysis and visualization resources, such } \\
\text { as network displays and statistical summaries to allow analysts to rapidly gain insights } \\
\text { into the behavior of networked systems. Loki-Infect, a social network model for } \\
\text { evaluating disease cascades, has been used to identify and evaluate mitigation } \\
\text { strategies for disease spread [NISAC 2011e]. }\end{array}$ \\
\hline$M B R A$ & $\begin{array}{l}\text { The MBRA tool supports the Model-Based Risk Assessment technique. There are two } \\
\text { key components of MBRA: the network analysis and the fault tree analysis. These } \\
\text { two parts can be performed independently or together. The network analysis models } \\
\text { an infrastructure network and helps the analyst to determine which components are } \\
\text { the most critical. The fault tree is an engineering technique used to model possible } \\
\text { faults to related parts of a system and then to determine how best to allocate resources } \\
\text { to those parts to minimize overall risk [CHDS 2011]. }\end{array}$ \\
\hline MIITS & $\begin{array}{l}\text { Multi-Scale Integrated Information and Telecommunications System (MIITS) module } \\
\text { is a scalable, end-to-end simulation environment for representing and analyzing } \\
\text { extremely large, complex communication networks of any type, including cellular } \\
\text { networks, public switched telephone networks (PSTNs), the Internet, and ad hoc mesh } \\
\text { networks. MIITS offers network representation in several resolutions, ranging from }\end{array}$ \\
\hline
\end{tabular}




\begin{tabular}{|c|c|}
\hline & $\begin{array}{l}\text { packet-level simulation to flow-based approaches. It is used as a part of the Urban } \\
\text { Infrastructure Suite (UIS) at NISAC [NISAC 2011f]. }\end{array}$ \\
\hline$M I N$ & $\begin{array}{l}\text { A three-layer Multi-Layer Infrastructure Networks (MIN) model is used to model } \\
\text { auto, urban freight, and data infrastructure and solved using Agent-Based Simulation. } \\
\text { This modeling uses a game-theoretic approach because the auto and freight flow } \\
\text { dynamics are based on a fixed-point formulation of a Cournot-Nash equilibrium of } \\
\text { games while travelers, travel information providers, freight shippers, and carriers are } \\
\text { treated as self-interest players in the games [Zhang 2005]. }\end{array}$ \\
\hline$M S M$ & $\begin{array}{l}\text { The MIT Screening Methodology (MSM) has been developed at the Massachusetts } \\
\text { Institute of Technology (MIT) for the identification and prioritization of } \\
\text { vulnerabilities in infrastructures. The infrastructures are modeled as interconnected } \\
\text { digraphs and employ graph theory to identify the candidate vulnerable scenarios. } \\
\text { These scenarios are screened for the susceptibility of their elements to a terrorist } \\
\text { attack, and a prioritized list of vulnerabilities is produced. The prioritization } \\
\text { methodology is based on multi-attribute utility theory. The impact of losing } \\
\text { infrastructure services is evaluated using a value tree that reflects the perceptions and } \\
\text { values of the decisionmaker and the relevant stakeholders. These results, which are } \\
\text { conditional on a specified threat, are provided to the decisionmaker for use in risk } \\
\text { management [Li 2009], [Apostolakas 2005]. }\end{array}$ \\
\hline MUNICIPAL & $\begin{array}{l}\text { Multi-Network Interdependent Critical Infrastructure Program for Analysis of } \\
\text { Lifelines (MUNICIPAL) is a decision support system for the design and assessment } \\
\text { of protection strategies including: identifying key elements to reduce the impact of } \\
\text { disruptions, determining what levels of effort are required to restore service, } \\
\text { designing alternative paths to reduce vulnerability, and determining where to site } \\
\text { emergency response resources to rapidly restore services after a disruption. } \\
\text { MUNICIPAL supports response and restoration following disruptions, facilitates } \\
\text { analysis of threat scenarios and supports emergency preparation and training activities } \\
\text { [Lee 2005]. }\end{array}$ \\
\hline$N-A B L E$ & $\begin{array}{l}\text { NISAC Agent-Based Laboratory for Economics (N-ABLE) is a large-scale } \\
\text { microeconomic simulation tool that captures complex internal supply chain and } \\
\text { market dynamics of businesses in the U.S. economy. It can be used to evaluate } \\
\text { policies through simulation of millions of interacting firms. It has been used to study } \\
\text { the impact of chlorine transportation disruption with a model of 3,300 related firms } \\
\text { and } 15000 \text { links [NISAC 2011g]. }\end{array}$ \\
\hline $\begin{array}{l}\text { Net-Centric } \\
\text { GIS }\end{array}$ & $\begin{array}{l}\text { A network-centric modeling approach is used and an infrastructure interdependency } \\
\text { knowledgebase is implemented in a WEBGIS environment for effective decision- } \\
\text { making process. The spatial knowledgebase mimics interrelationships between } \\
\text { selected critical infrastructure sectors. The approach can be used for effectively } \\
\text { addressing the issues of infrastructure interdependency during emergencies [Abdalla } \\
\text { 2007]. }\end{array}$ \\
\hline $\begin{array}{l}\text { NG Analysis } \\
\text { Tools }\end{array}$ & $\begin{array}{l}\text { Natural gas (NGx) analysis tools allow modeling of the natural gas pipeline } \\
\text { infrastructure. NGflow identifies critical links and nodes in a network topology. } \\
\text { NGanalyzer assists users in analyzing identified gas engineering vulnerabilities, such } \\
\text { as the number of city-gates, available storage, and pipeline capacity and }\end{array}$ \\
\hline
\end{tabular}




\begin{tabular}{|c|c|}
\hline & $\begin{array}{l}\text { interconnection. NGcut determines network component failure sets that could isolate } \\
\text { a specific location or site from all supply sources. NGdepletion addresses outage } \\
\text { duration times and determines whether and when a component outage will affect a } \\
\text { specific location or site. NGpressure determines how the loss of a critical link or node } \\
\text { under various operating conditions might affect a natural gas system [ANL 2011b]. }\end{array}$ \\
\hline NSRAM & $\begin{array}{l}\text { Network Security Risk Assessment Model (NSRAM) is a tool for determining the } \\
\text { probability of failure and repair/recovery time of complex systems composed of a } \\
\text { network or system of networks. It models interconnected networks, such as electrical } \\
\text { grids, communication systems, and roadways. Its features include: a time domain } \\
\text { probabilistic risk assessment method, an ability to analyze the interaction of disparate } \\
\text { network elements, and a detailed repair simulation capability [IIIA 2007]. }\end{array}$ \\
\hline PipelineNet & $\begin{array}{l}\text { PipelineNet is a Windows stand-alone PC application that integrates hydraulic and } \\
\text { water quality models from EPA's EPANET } 2.0 \text { with existing databases to give } \\
\text { emergency managers real time information for estimating the risks to public water } \\
\text { supplies. PipelineNet simulates the flow and concentration of biological or chemical } \\
\text { contaminants in a city or municipality's water distribution system from single and } \\
\text { multiple sources, simulates water tracing and ageing, aids in the location of } \\
\text { monitoring sites, provides tools for regulatory compliance and helps to evaluate } \\
\text { contamination mitigation alternatives [SAIC 2011]. }\end{array}$ \\
\hline Restore & $\begin{array}{l}\text { Restore models complex sets of steps required to accomplish a goal, such as repairing } \\
\text { a ruptured natural gas pipeline, when the time required to complete a step may be } \\
\text { uncertain due to such factors as the time of day, weather, and availability of crew. } \\
\text { Restore allows a user to estimate the time and cost (which may also be uncertain) } \\
\text { needed to achieve an intermediate stage of completion, as well as overall completion. } \\
\text { The tool also identifies the "most active path" through the network of tasks. It } \\
\text { generates output graphs of probability distributions for overall and intermediate } \\
\text { completion times [ANL 2011c]. }\end{array}$ \\
\hline$R-N A S$ & $\begin{array}{l}\text { R-NAS is a network flow model of primary rail tracks, yards, bridges and other rail } \\
\text { facilities in the continental U.S., with flow based on commodity movement data from } \\
\text { the Department of Transportation. The model can be used for quantifying the impact } \\
\text { of disruptions in the network. Network flow optimization routines can be used to } \\
\text { reroute the flows to support trans-incident operations support. The model has been } \\
\text { used to analyze the impact of Hurricane Katrina on the rail network [NISAC 2011b]. }\end{array}$ \\
\hline RTDS & $\begin{array}{l}\text { Real Time Digital Simulator (RTDS) provides power systems simulation technology } \\
\text { for study of power systems with complex High Voltage Alternating Current (HVAC) } \\
\text { and High Voltage Direct Current (HVDC) networks. It is a fully digital } \\
\text { electromagnetic transients power system simulator that operates in real time. Since } \\
\text { the simulator functions in real-time the power system algorithms are calculated } \\
\text { quickly enough to continuously produce output conditions which realistically } \\
\text { represent conditions in a real network. The simulator can be directly connected to the } \\
\text { power system control and protection equipment for running simulations [INL 2010]. }\end{array}$ \\
\hline TEVA & $\begin{array}{l}\text { Threat Ensemble Vulnerability Assessment (TEVA) is a probabilistic framework for } \\
\text { assessing the vulnerability of a water utility to a large range of contamination attacks. } \\
\text { TEVA addresses the spatial and temporal complexities of water-distribution networks }\end{array}$ \\
\hline
\end{tabular}




\begin{tabular}{|c|c|}
\hline & $\begin{array}{l}\text { by integrating network hydraulic models with water-quality models, health-impact } \\
\text { models, and sensor-placement algorithms. The integrated set of models allows } \\
\text { decision makers to assess the potential health impacts of a variety of contamination } \\
\text { scenarios; to design and evaluate possible mitigation strategies, such as a contaminant } \\
\text { warning system; and to plan effective response activities, such as containment and } \\
\text { public health intervention [ANL 2011d]. }\end{array}$ \\
\hline TRAGIS & $\begin{array}{l}\text { The Transportation Routing Analysis Geographic Information System (TRAGIS) } \\
\text { model is used to calculate highway, rail, or waterway routes within the United States. } \\
\text { TRAGIS is a client-server application with the user interface and map data files } \\
\text { residing on the user's personal computer and the routing engine and network data files } \\
\text { on a network server. The user can also view a detailed listing of the route and } \\
\text { population-density information, which can be used with other risk models [ORNL } \\
\text { 2006]. }\end{array}$ \\
\hline TRANSIMS & $\begin{array}{l}\text { Transportation Analysis Simulation System (TRANSIMS) simulates the daily } \\
\text { activities and movements of individuals in an urban region. The individuals are } \\
\text { synthetic - they do not represent actual people-but a census taken on the entire } \\
\text { synthetic population would be statistically identical. The locations visited by } \\
\text { individuals are real street addresses and reflect actual land-use patterns in the region. } \\
\text { It provides the following information about the synthetic population and its mobility: } \\
\text { household structure and demographics, activity locations, times, and durations, and } \\
\text { trips between activities, including route plans and execution of the route plans on the } \\
\text { transportation network. It is also used as a module in Urban Infrastructure Suite } \\
\text { (UIS) at NISAC [NISAC 2011h]. }\end{array}$ \\
\hline UIS & $\begin{array}{l}\text { Urban Infrastructure Suite (UIS) is a set of seven interoperable modules that employ } \\
\text { advanced modeling and simulation methodologies to represent urban infrastructures } \\
\text { and populations. These simulation-based modules are linked through a common } \\
\text { interface for the flow of information between UIS sector simulations to model urban } \\
\text { transportation, telecommunications, public health, energy (IEISS), financial } \\
\text { (commodity markets), and water-distribution (WISE) infrastructures and their } \\
\text { interdependencies [NISAC 2011i]. }\end{array}$ \\
\hline VISAC & $\begin{array}{l}\text { Visual Interactive Site Analysis Code (VISAC) is a Java-based expert system that } \\
\text { provides mission planners with a coordinated capability to predict and analyze the } \\
\text { outcomes of different accidents/incidents at various nuclear and industrial facilities. } \\
\text { The incidents can range from simple individual equipment sabotage to complex } \\
\text { sorties that utilize a range of military weapons, simulated truck or car bombs, or } \\
\text { satchel charges. The target facility is generated by either customizing existing 3-D } \\
\text { CAD models for near real-time analysis or creating a new model from scratch. Using } \\
\text { event/fault tree methodology, VISAC provides the probability of facility kill, the } \\
\text { probability of undesirable collateral effects (chemical or radiological releases), and an } \\
\text { estimate of facility down time [ORNL 2004]. }\end{array}$ \\
\hline WISE & $\begin{array}{l}\text { Water Infrastructure Simulation Environment (WISE) is an analytic framework } \\
\text { supporting the evaluation of water infrastructure in terms of both infrastructure } \\
\text { specific and interdependency issues. Analysts can use WISE to study transmission } \\
\text { scale water distribution systems, define and simulate flood events due to excess } \\
\text { rainfall and hurricane storm surge, create spatial estimates of water demand, simulate }\end{array}$ \\
\hline
\end{tabular}




\begin{tabular}{|l|l|}
\hline & $\begin{array}{l}\text { water distribution system hydraulics and water quality using EPANET, build water } \\
\text { distribution network models within a GIS and visualize output from EPANET within } \\
\text { a GIS [NISAC 2011j]. }\end{array}$ \\
\hline
\end{tabular}

\subsection{Relevant Standards and Guidelines}

This section identifies standards and guidelines that are potentially relevant to the development of M\&S applications for CIKR systems. The standards and guidelines may include mechanisms and formats for the interchange of data, data storage, generation of information displays, integration of systems, and/or conceptualization and design of CIKR M\&S applications. Subsection 1 includes the standards that are specific to CIKR domain. The following subsections list standards that are common across the homeland security applications of M\&S and focus on conceptual modeling, distributed simulation, geographical information system (GIS), and communications respectively.

\subsubsection{Domain Specific Standards}

\begin{tabular}{|l|l|}
\hline \multicolumn{1}{|c|}{ Standard Title } & \multicolumn{1}{c|}{ Overview } \\
\hline $\begin{array}{l}\text { Building Escape and Evacuation } \\
\text { Plans }\end{array}$ & $\begin{array}{l}\text { Description: The standard establishes design principles for } \\
\text { displayed escape plans that provide information vital to fire } \\
\text { safety, escape, evacuation, and rescue of a facility's occupants. } \\
\text { These plans may also be used by intervention forces in case of } \\
\text { terrorist attack [ISO 2011a]. } \\
\text { Standard Type: ISO 23601:2009 } \\
\text { Organization: ISO } \\
\text { Classification: Operational guidelines }\end{array}$ \\
\hline $\begin{array}{ll}\text { Caltech-USGS Broadcast of } \\
\text { Format }\end{array}$ & $\begin{array}{l}\text { Description: A message format used to report earthquake } \\
\text { broadcast message from the Caltech-USGS Broadcast of } \\
\text { Earthquakes (CUBE) system, a real-time notification system for } \\
\text { earthquake information. CUBE message consists of an } \\
\text { identification segment, earthquake's time, location, magnitude, } \\
\text { depth, etc. [USGS 2011a]. } \\
\text { Standard Type: Government specification } \\
\text { Organization: California Institute of Technology Seismological } \\
\text { Laboratory (Caltech); United States Geological Survey (USGS) } \\
\text { Classification: Document format }\end{array}$ \\
\hline $\begin{array}{l}\text { Center-to-Center (C2C) Naming } \\
\text { Convention Specification }\end{array}$ & $\begin{array}{l}\text { Description: This standard provides a standard way for } \\
\text { transportation management centers to uniquely name entities for } \\
\text { which data are exchanged with other centers. It also lists the } \\
\text { requirements for establishing names for management systems } \\
\text { and for the objects managed by those systems [NTCIP 2011]. } \\
\text { Standard Type: NTCIP 1104:2008 Version 01.09 } \\
\text { Organization: American Association of State Highway and } \\
\text { Transportation Officials (AASHTO); Institute of } \\
\text { Transportation Engineers (ITE); National Electrical } \\
\text { Manufacturers Association (NEMA) } \\
\text { Classification: Domain-specific integration interface }\end{array}$ \\
\hline
\end{tabular}




\begin{tabular}{|c|c|}
\hline $\begin{array}{l}\text { Common Incident Management } \\
\text { Message Sets for use by Emergency } \\
\text { Management Centers (IEEE } 1512 \\
\text { Family of Standards) }\end{array}$ & $\begin{array}{l}\text { Description: An IEEE Family of standards for traffic incident } \\
\text { management that provides incident management message sets } \\
\text { common to traffic management, public safety, and hazardous } \\
\text { materials incident response activities. The standards address the } \\
\text { intercommunication needs of emergency management centers } \\
\text { and other types of centers engaged in transportation incident } \\
\text { management [IEEE 2011a]. } \\
\text { Standard Type: IEEE 1512-2006; IEEE 1512.1-2003; IEEE } \\
\text { 1512.2-2004; IEEE 1512.3-2006 } \\
\text { Organization: Institute of Electrical and Electronics Engineers } \\
\text { (IEEE); Federal Highway Administration (FHWA) } \\
\text { Classification: Domain-specific integration interface }\end{array}$ \\
\hline $\begin{array}{l}\text { Communicable Disease Surveillance } \\
\text { and Response Systems: A Guide to } \\
\text { Planning }\end{array}$ & $\begin{array}{l}\text { Description: This planning guide is to assist Member States to } \\
\text { develop and/or refine comprehensive and cohesive plans for } \\
\text { implementing and strengthening surveillance and response } \\
\text { systems. It is anticipated that planners at all levels of the health } \\
\text { system will find this guide useful as a general framework for } \\
\text { developing a vision, strategies and routine operational plans for } \\
\text { strengthening surveillance and response systems [WHO 2011a]. } \\
\text { Standard Type: WHO/CDS/EPR/LYO/2006.1 } \\
\text { Organization: The World Health Organization (WHO) } \\
\text { Classification: Operational guidelines }\end{array}$ \\
\hline $\begin{array}{l}\text { Communicable Disease Surveillance } \\
\text { and Response Systems: Guide to } \\
\text { Monitoring and Evaluating }\end{array}$ & $\begin{array}{l}\text { Description: This guide is to support implementation of } \\
\text { monitoring and evaluation of communicable disease surveillance } \\
\text { and response systems at country level. It was reviewed by } \\
\text { experts in communicable disease surveillance and response } \\
\text { systems, and pre-tested in Estonia and Ethiopia. This guide } \\
\text { aims to assist countries in formulating and implementing } \\
\text { monitoring and evaluation strategies [WHO 2011b]. } \\
\text { Standard Type: WHO/CDS/EPR/LYO/2006.2 } \\
\text { Organization: the World Health Organization (WHO) } \\
\text { Classification: Operational guidelines }\end{array}$ \\
\hline $\begin{array}{l}\text { Community-Based Mass } \\
\text { Prophylaxis: A Planning Guide for } \\
\text { Public Health Preparedness }\end{array}$ & $\begin{array}{l}\text { Description: A planning guide is used to help state, county, \& } \\
\text { local officials meet federal requirements to prepare for public } \\
\text { health emergencies. Outlines five components of mass } \\
\text { prophylaxis response to epidemic outbreaks: surveillance, } \\
\text { stockpiling, distribution, dispensing, and follow up. Addresses } \\
\text { dispensing operations using a comprehensive operational } \\
\text { structure for Dispensing/Vaccination Centers (DVCs) based on } \\
\text { the National Incident Management System (NIMS) [AHRQ } \\
\text { 2011a]. } \\
\text { Standard Type: Specification } \\
\text { Organization: The Agency of Healthcare Research \& Quality } \\
\text { (AHRQ) } \\
\text { Classification: Operational guidelines }\end{array}$ \\
\hline
\end{tabular}




\begin{tabular}{|c|c|}
\hline $\begin{array}{l}\text { Converting ATIS Message Standards } \\
\text { from ASN.1 to XML }\end{array}$ & $\begin{array}{l}\text { Description: This SAE Standard presents a set of rules for } \\
\text { transforming an Abstract Syntax Notation (ASN.1) message set } \\
\text { definition into an eXtensible Markup Language (XML) schema. } \\
\text { The result is intended to be a stand-alone XML Schema that is } \\
\text { fully consistent with an existing ASN.1 information model [SAE } \\
\text { 2011b]. } \\
\text { Standard Type: SAE J2630 } \\
\text { Organization: Society of Automotive Engineers (SAE) } \\
\text { International } \\
\text { Classification: Domain-specific integration interface }\end{array}$ \\
\hline $\begin{array}{l}\text { Data Dictionaries for Intelligent } \\
\text { Transportation Systems }\end{array}$ & $\begin{array}{l}\text { Description: The expanding use of digital communications } \\
\text { among subsystems of the transportation infrastructure has } \\
\text { spawned the development of data dictionaries for the } \\
\text { communications between these subsystems. A format for } \\
\text { intelligent transportation system (ITS) data dictionaries, } \\
\text { including common terms (e.g. time, date, location), as well as } \\
\text { the meta-attributes necessary to document ITS data concepts, is } \\
\text { addressed in this standard [IEEE 2011b]. } \\
\text { Standard Type: IEEE 1489-1999 } \\
\text { Organization: IEEE } \\
\text { Classification: Domain-specific integration interface }\end{array}$ \\
\hline $\begin{array}{l}\text { Earthquake Instrumentation Criteria } \\
\text { for Nuclear Power Plants }\end{array}$ & $\begin{array}{l}\text { Description: This standard specifies the required earthquake } \\
\text { instrumentation for the site and structures of light-water-cooled, } \\
\text { land-based nuclear power plants. It may be used for guidance at } \\
\text { other types of nuclear facilities [ANS 2011]. } \\
\text { Standard Type: ANSI/ANS-2.2-2002 } \\
\text { Organization: ANSI; American Nuclear Society (ANS) } \\
\text { Classification: Operational guidelines }\end{array}$ \\
\hline $\begin{array}{l}\text { Electronic Data Interchange for } \\
\text { Administration, Commerce, and } \\
\text { Transport (EDIFACT) }\end{array}$ & $\begin{array}{l}\text { Description: EDIFACT is an international electronic data } \\
\text { interchange (EDI) standard developed under the United Nations } \\
\text { and has been adopted by ISO as the ISO standard, ISO 9735. } \\
\text { The standard gives syntax rules for the preparation of messages } \\
\text { to be interchanged between partners in the fields of } \\
\text { administration, commerce, and transport. ISO/TS 20625:2002 } \\
\text { (or Electronic Data Interchange for Administration, Commerce } \\
\text { and Transport (EDIFACT) - Rules for Generation of XML } \\
\text { Scheme Files (XSD) on the Basis of EDI(FACT) } \\
\text { implementation guidelines), describes how to derive XML from } \\
\text { UN/EDIFACT Message Implementation Guides (MIGs) [ISO } \\
\text { 2011d]. } \\
\text { Standard Type: ISO 9735-1:2002; ISO 9735-2:2002; ISO } \\
\text { 9735-3:2002; ISO 9735-4:2002; ISO 9735-5:2002; ISO 9735- } \\
\text { 6:2002; ISO 9735-7:2002; ISO 9735-8:2002; ISO 9735-9:2002; } \\
\text { ISO 9735-10:2002; ISO/TS 20625:2002 } \\
\text { Organization: ISO } \\
\text { Classification: Domain-specific integration interface }\end{array}$ \\
\hline
\end{tabular}




\begin{tabular}{|c|c|}
\hline $\begin{array}{l}\text { Field Management Stations (FMS) - } \\
\text { Part 1: Object Definitions for Signal } \\
\text { System Masters }\end{array}$ & $\begin{array}{l}\text { Description: This standard provides the vocabulary (commands, } \\
\text { responses and information) necessary for traffic management } \\
\text { and operations personnel to control, manage and monitor signal } \\
\text { system masters. The standard also includes a protocol } \\
\text { requirements list (PRL) and a requirements traceability matrix } \\
\text { providing object conformity information [NTCIP 2011]. } \\
\text { Standard Type: NTCIP 1210:2009 Version 01.52 } \\
\text { Organization: American Association of State Highway and } \\
\text { Transportation Officials (AASHTO); Institute of } \\
\text { Transportation Engineers (ITE); National Electrical } \\
\text { Manufacturers Association (NEMA) } \\
\text { Classification: Domain-specific integration interface }\end{array}$ \\
\hline $\begin{array}{l}\text { Health informatics - Genomic } \\
\text { Sequence Variation Markup } \\
\text { Language (GSVML) }\end{array}$ & $\begin{array}{l}\text { Description: ISO } 25720: 2009 \text { is applicable to the data exchange } \\
\text { format that is designed to facilitate the exchange of the genomic } \\
\text { sequence variation data around the world, without forcing } \\
\text { change of any database schema. From an informatics } \\
\text { perspective, GSVML defines the data exchange format based on } \\
\text { XML. The scope of ISO 25720:2009 is the data exchange } \\
\text { format, but the database schema itself is outside the scope of this } \\
\text { International Standard. From a biological point of view, all } \\
\text { genetic sequence variations are taken into consideration and are } \\
\text { within the scope of this International Standard, while } \\
\text { polymorphisms, especially single nucleotide polymorphism } \\
\text { (SNP), are the main focus of this International Standard [ISO } \\
\text { 2011b]. } \\
\text { Standard Type: ISO 25720:2009 } \\
\text { Organization: ISO } \\
\text { Classification: Domain-specific integration interface }\end{array}$ \\
\hline $\begin{array}{l}\text { IEEE Safety and Security Standards } \\
\text { Series }\end{array}$ & $\begin{array}{l}\text { Description: The IEEE standards Association has prepared a } \\
\text { three-volume Safety \& Security standard series to assist the } \\
\text { development of the organization's safety, security, and } \\
\text { emergency management plans where Volume } 1 \text { is about critical } \\
\text { infrastructure, Volume } 2 \text { is about computers and networks, and } \\
\text { Volume } 3 \text { is about electrical systems. [IEEE 2011d] [IEEE } \\
\text { 2011e] [IEEE 2011f]. } \\
\text { Standard Type: IEEE STDVU121; IEEE STDVU122; IEEE } \\
\text { STDVU123 } \\
\text { Organization: IEEE } \\
\text { Classification: Operational guidelines }\end{array}$ \\
\hline $\begin{array}{l}\text { Information Technology- } \\
\text { Multimedia Content Description } \\
\text { Interface }\end{array}$ & $\begin{array}{l}\text { Description: ISO/IEC } 15938 \text { is a family of standards, under the } \\
\text { general title of Information technology - Multimedia content } \\
\text { description interface, provides multimedia content description } \\
\text { interface including geographic. It consists of } 8 \text { parts: systems, } \\
\text { description definition language, visual, audio, multimedia } \\
\text { description schemes, reference software, conformance testing, } \\
\text { and extraction and use of Multimedia Content Description } \\
\text { Interface (MPEG-7) description [ISO 2011b]. } \\
\text { Standard Type: ISO/IEC 15938-1:2002, ISO/IEC 15938- }\end{array}$ \\
\hline
\end{tabular}




\begin{tabular}{|c|c|}
\hline & $\begin{array}{l}\text { 1:2002/Amd 1:2005/Cor 1:2005; ISO/IEC 15938-1:2002/Cor } \\
\text { 1:2004; ISO/IEC 15938-1:2002/Cor 2:2005; ISO/IEC 15938- } \\
\text { 1:2002/Amd 1:2005; ISO/IEC 15938-1:2002/Amd 2:2006; } \\
\text { ISO/IEC 15938-2:2002; ISO/IEC 15938-3:2002; ISO/IEC } \\
\text { 15938-4:2002; ISO/IEC 15938-5:2003; ISO/IEC 15938-6:2003; } \\
\text { ISO/IEC 15938-7:2003; ISO/IEC TR 15938-8:2002; ISO/IEC } \\
\text { 15938-9:2005; ISO/IEC 15938-10:2005; ISO/IEC TR 15938- } \\
\text { 11:2005; ISO/IEC 15938-12:2008 } \\
\text { Organization: ISO; International Electrotechnical Commission } \\
\text { (IEC) } \\
\text { Classification: Domain-specific integration interface }\end{array}$ \\
\hline $\begin{array}{l}\text { International Classification of } \\
\text { Diseases }\end{array}$ & $\begin{array}{l}\text { Description: An official system of assigning codes to diagnoses } \\
\text { and procedures associated with hospital utilization. The National } \\
\text { Center for Health Statistics (NCHS), the Federal agency } \\
\text { responsible for use of the International Statistical Classification } \\
\text { of Diseases and Related Health Problems, } 10^{\text {th }} \text { revision (ICD-10) } \\
\text { in the United States, has developed a clinical modification of the } \\
\text { classification for morbidity purposes. The ICD-10 is used to } \\
\text { code and classify mortality data from death certificates, having } \\
\text { replaced ICD-9 for this purpose as of January 1, 1999. ICD-10- } \\
\text { CM is planned as the replacement for ICD-9-CM [CDC 2011a]. } \\
\text { Standard Type: International Classification of Diseases, } \\
10^{\text {th }} \text { Revision; Clinical Modification (ICD-10-CM) } \\
\text { Organization: World Health Organization (WHO); National } \\
\text { Center for Health Statistics (NCHS); Centers for Medicare and } \\
\text { Medicaid Services } \\
\text { Classification: Operational guidelines }\end{array}$ \\
\hline Keyhole Markup Language (KML) & $\begin{array}{l}\text { Description: This standard is about an XML grammar and file } \\
\text { format for modeling and storing geographic features such as } \\
\text { points, lines, images, and polygons for display in GIS } \\
\text { applications. KML is focused on geographic visualization, } \\
\text { including annotation of maps and images. Geographic } \\
\text { visualization includes not only the presentation of graphical data } \\
\text { on the globe, but also the control of the user's navigation in the } \\
\text { sense of where to go and where to look [OGC 2011b]. } \\
\text { Standard Type: KML 2.2-2007 } \\
\text { Organization: Google Inc.; Open Geospatial Consortium } \\
\text { (OGC) } \\
\text { Classification: Document format }\end{array}$ \\
\hline $\begin{array}{l}\text { Multi-Purpose Weather Products } \\
\text { Specification }\end{array}$ & $\begin{array}{l}\text { Description: This procedural directive provides detailed } \\
\text { information on products Weather Forecast Offices (WFO) and } \\
\text { the Storm Prediction Center (SPC) issue for severe, fire, marine, } \\
\text { tropical, winter and/or non-precipitation weather and flooding } \\
\text { hazards. } \\
\text { Standard Type: NWSI 10-517 } 2005 \\
\text { Organization: National Weather Service (NWS); NOAA } \\
\text { Classification: Domain-specific integration interface }\end{array}$ \\
\hline
\end{tabular}




\begin{tabular}{|c|c|}
\hline $\begin{array}{l}\text { National Highway Traffic Safety } \\
\text { Administration (NHTSA) Data } \\
\text { Dictionary }\end{array}$ & $\begin{array}{l}\text { Description: The data dictionary, used to create the National } \\
\text { Highway Traffic Safety Administration's Uniform Pre-Hospital } \\
\text { Emergency Medical Services (EMS) Dataset, provides over } 400 \\
\text { definitions that can be implemented by an Emergency Medical } \\
\text { Services (EMS) system. Information provided in the dictionary } \\
\text { includes name, definition, data type, medical record information, } \\
\text { variables associated, relation to other national data tools, data } \\
\text { provider, etc. [UIC 2011]. } \\
\text { Standard Type: NHTSA Uniform PreHospital EMS Dataset } \\
\text { Version 2.2.1 (2006) } \\
\text { Organization: National Highway Traffic Safety Administration } \\
\text { (NHTSA) } \\
\text { Classification: Document format }\end{array}$ \\
\hline $\begin{array}{l}\text { National Infrastructure Protection } \\
\text { Plan (NIPP) }\end{array}$ & $\begin{array}{l}\text { Description: The National Infrastructure Protection Plan (NIPP) } \\
\text { is a coordinated strategy that defines critical infrastructure and } \\
\text { key resources (CIKR) protection roles and responsibilities for } \\
\text { federal, state, local, tribal, and private sector security partners. } \\
\text { The NIPP sets national priorities, goals, and requirements for } \\
\text { effective distribution of resources which will enable the } \\
\text { government, economy, and public services to continue in the } \\
\text { event of a terrorist attack or other disaster. The plan provides } \\
\text { the unifying structure for the integration of a wide range of } \\
\text { efforts for the enhanced protection and resiliency of the nation's } \\
\text { CIKR into a single national program [DHS 2009]. } \\
\text { Standard Type: The } 2009 \text { National Infrastructure Protection } \\
\text { Plan } \\
\text { Organization: Department of Homeland Security } \\
\text { Classification: Operational guidelines }\end{array}$ \\
\hline $\begin{array}{l}\text { Object Definitions for Actuated } \\
\text { Traffic Signal Controller Units }\end{array}$ & $\begin{array}{l}\text { Description: A National Transportation Communications for } \\
\text { the Institute of Transportation Engineers (ITS) Protocol } \\
\text { (NTCIP) standard where NTCIP is a family of communication } \\
\text { protocols for traffic management devices. The standard defines } \\
\text { the data elements and conformance requirements for actuated } \\
\text { traffic signal controllers (ASC) [NTCIP 2011]. The data in the } \\
\text { standard is defined using specifications from the internet, and } \\
\text { expresses a signal system's operating parameters, functional } \\
\text { controls, and status information. Some of these functions } \\
\text { include: signal phases, detectors, coordination, preemption, } \\
\text { upload and download, and block object data for efficient device } \\
\text { configuration. } \\
\text { Standard Type: NTCIP 1202:2005, Version 02 } \\
\text { Organization: American Association of State Highway and } \\
\text { Transportation Officials (AASHTO); Institute of Transportation } \\
\text { Engineers (ITE); National Electrical Manufacturers Association } \\
\text { (NEMA) } \\
\text { Classification: Document format }\end{array}$ \\
\hline $\begin{array}{l}\text { Object Definitions for Closed Circuit } \\
\text { Television (CCTV) Camera Control }\end{array}$ & $\begin{array}{l}\text { Description: This standard defines data elements required to } \\
\text { control video cameras and also defines standardized object }\end{array}$ \\
\hline
\end{tabular}




\begin{tabular}{|c|c|}
\hline & $\begin{array}{l}\text { Groups which can be used for conformance statements [NTCIP } \\
\text { 2011]. It provides the vocabulary - commands, responses and } \\
\text { information - necessary for traffic management and operations } \\
\text { personnel to control, manage, and monitor cameras, lenses and } \\
\text { pan/tilt units. This standard contains object definitions to } \\
\text { support the functionality of these devices as used for } \\
\text { transportation and traffic monitoring applications. The standard } \\
\text { includes conformance group requirements and conformance } \\
\text { statements to support compliance with the standard. } \\
\text { Standard Type: NTCIP 1205:2001, Version 01.08 } \\
\text { Organization: American Association of State Highway and } \\
\text { Transportation Officials (AASHTO); Institute of } \\
\text { Transportation Engineers (ITE); National Electrical } \\
\text { Manufacturers Association (NEMA) } \\
\text { Classification: Document format }\end{array}$ \\
\hline $\begin{array}{l}\text { Object Definitions for Dynamic } \\
\text { Message Signs (DMS) }\end{array}$ & $\begin{array}{l}\text { Description: This standard provides the vocabulary - } \\
\text { commands, responses, and information - necessary for traffic } \\
\text { management and operations personnel to advise and inform the } \\
\text { vehicle operators of current highway conditions by using } \\
\text { dynamic message signs. A dynamic message sign is any sign } \\
\text { that can change the message presented to the viewer. The } \\
\text { standard also includes a Protocol Requirements List table, } \\
\text { standardized data exchange dialogs, a Requirements Traceability } \\
\text { Matrix, etc. [NTCIP 2011]. } \\
\text { Standard Type: NTCIP 1203: 1997, Version 01.15 } \\
\text { Organization: American Association of State Highway and } \\
\text { Transportation Officials (AASHTO); Institute of } \\
\text { Transportation Engineers (ITE); National Electrical } \\
\text { Manufacturers Association (NEMA) } \\
\text { Classification: Document format }\end{array}$ \\
\hline $\begin{array}{l}\text { Object Definitions for Environmental } \\
\text { Sensor Stations (ESS) }\end{array}$ & $\begin{array}{l}\text { Description: The standard provides the vocabulary - } \\
\text { commands, responses, and information - necessary for the } \\
\text { management of environmental sensor stations, including road } \\
\text { weather information systems (RWIS), air quality monitoring } \\
\text { systems, and pavement treatment systems (PTS) [NTCIP 2011]. } \\
\text { Standard Type: NTCIP 1204, Version 03 } \\
\text { Organization: American Association of State Highway and } \\
\text { Transportation Officials (AASHTO); Institute of } \\
\text { Transportation Engineers (ITE); National Electrical } \\
\text { Manufacturers Association (NEMA) } \\
\text { Classification: Document format }\end{array}$ \\
\hline $\begin{array}{l}\text { Object Definitions for } \\
\text { Transportation Sensor Systems (TSS) }\end{array}$ & $\begin{array}{l}\text { Description: The standard defines the user needs and features, } \\
\text { functional requirements, and standardized data element and } \\
\text { message dialog definitions for Transportation Sensor Systems } \\
\text { (TSS) [NCTIP 2011]. It provides the vocabulary - commands, } \\
\text { responses and information - necessary for traffic management } \\
\text { and operations personnel to control, manage, and monitor } \\
\text { transportation sensor system devices. These devices include }\end{array}$ \\
\hline
\end{tabular}




\begin{tabular}{|c|c|}
\hline & $\begin{array}{l}\text { smart inductive loop amplifiers, machine vision video detection, } \\
\text { and microwave radar monitoring systems. } \\
\text { Standard Type: NTCIP 1209:2005, Version 01.19; NTCIP } \\
\text { 1209, Version } 2 \text { (Recommended standard) } \\
\text { Organization: American Association of State Highway and } \\
\text { Transportation Officials (AASHTO); Institute of } \\
\text { Transportation Engineers (ITE); National Electrical } \\
\text { Manufacturers Association (NEMA) } \\
\text { Classification: Document format }\end{array}$ \\
\hline $\begin{array}{l}\text { On-Board Land Vehicle Mayday } \\
\text { Reporting Interface }\end{array}$ & $\begin{array}{l}\text { Description: This standard addresses the responsibilities of a } \\
\text { vehicle in detecting and reporting the event associated with } \\
\text { either the intelligent vehicle itself or by the intelligent roadway } \\
\text { of the vehicle that is disabled or involved. It proscribes a basic } \\
\text { methodology to uniformly incorporate whatever level of data } \\
\text { reporting the vehicle supports (containing information about } \\
\text { both the vehicle condition and any occupant data), and transmits } \\
\text { this data to the response management agency in a Nationally } \\
\text { standardized format, regardless of the transmission media used } \\
\text { to effect the communications [SAE 2011a]. The standard is } \\
\text { intended for use by private industry (e.g., manufacturers) and } \\
\text { public safety and emergency response agencies (at the } \\
\text { receiving/dispatching point) at local, state, and national levels. } \\
\text { Receiving devices are expected to be found at local public } \\
\text { response dispatch points (primary safety answering points). } \\
\text { Standard Type: SAE J2313 } \\
\text { Organization: Society of Automotive Engineers (SAE) } \\
\text { International } \\
\text { Classification: Operational guidelines }\end{array}$ \\
\hline $\begin{array}{l}\text { Pandemic Phase Descriptions and } \\
\text { Main Actions by Phase }\end{array}$ & $\begin{array}{l}\text { Description: This document defines pandemic phases and main } \\
\text { actions by phase. The pandemic phases include phases 1-6, post } \\
\text { peak period, and post pandemic period [WHO 2011c] } \\
\text { Standard Type: WHO specification } \\
\text { Organization: World Health Organization (WHO) } \\
\text { Classification: Operational guidelines }\end{array}$ \\
\hline $\begin{array}{l}\text { Practice for Metadata to Support } \\
\text { Archived Data Management Systems }\end{array}$ & $\begin{array}{l}\text { Description: This standard practice describes a hierarchical } \\
\text { outline of sections and elements to be used in developing } \\
\text { metadata to support archived data management systems. } \\
\text { Specifically, the standard establishes the names of metadata } \\
\text { elements and compound elements to be used in the metadata, the } \\
\text { definitions of these metadata elements and compound elements, } \\
\text { and suggested information about and examples of the values that } \\
\text { are to be provided for the metadata elements. This standard is } \\
\text { applicable to various types of operational data collected by } \\
\text { intelligent transportation systems (ITS) and stored in an archived } \\
\text { data management system. Similarly, the standard can also be } \\
\text { used with other types of historical traffic and transportation data } \\
\text { collected and stored in an archived data management system } \\
\text { [ASTM 2011a]. }\end{array}$ \\
\hline
\end{tabular}




\begin{tabular}{|c|c|}
\hline & $\begin{array}{l}\text { Standard Type: ASTM E2468-05 } \\
\text { Organization: ASTM International } \\
\text { Classification: Domain-specific integration interface }\end{array}$ \\
\hline $\begin{array}{l}\text { Protocol for the Assessment of } \\
\text { National Communicable Disease } \\
\text { Surveillance and Response Systems: } \\
\text { Guidelines for Assessment Teams }\end{array}$ & $\begin{array}{l}\text { Description: This manual has been developed for World Health } \\
\text { Organization (WHO) staff and partners carrying out assessments } \\
\text { of national communicable disease surveillance systems with a } \\
\text { national team. It will help WHO staff and consultants guide a } \\
\text { group of national professionals through an assessment of the } \\
\text { overall structure and performance of surveillance activities in a } \\
\text { Member State. This assessment should lead to a standardized } \\
\text { report and an agreed plan of action. The manual also outlines a } \\
\text { suggested reporting format with tables for implementation plans } \\
\text { [WHO 2011d]. } \\
\text { Standard Type: WHO/CDS/CSR/ISR/2001/2/EN } \\
\text { Organization: The World Health Organization (WHO) } \\
\text { Classification: Operational guidelines; Document format }\end{array}$ \\
\hline $\begin{array}{l}\text { Public Health Emergency Response } \\
\text { Guide for State, Local, \& Tribal } \\
\text { Public Health Directors }\end{array}$ & $\begin{array}{l}\text { Description: The Public Health Emergency Response Guide is } \\
\text { used for State, Local, and Tribal Public Health Directors. The } \\
\text { guide is an all-hazards reference tool for health professionals } \\
\text { who are responsible for initiating the public health response } \\
\text { during the first } 24 \text { hours (i.e., the acute phase) of an emergency } \\
\text { or disaster. It also contains guidance that is applicable to specific } \\
\text { types of incidents, such as floods, earthquakes, and acts of } \\
\text { terrorism [CDC 2011b]. } \\
\text { Standard Type: Specification } \\
\text { Organization: The National Center for Environmental Health } \\
\text { (NCEH), Division of Emergency and Environmental Health } \\
\text { Services (EEHS), the Centers for Disease Control and } \\
\text { Prevention (CDC) } \\
\text { Classification: Operational guidelines }\end{array}$ \\
\hline $\begin{array}{l}\text { Radio Data System- Traffic Message } \\
\text { Channel (RDS-TMC) }\end{array}$ & $\begin{array}{l}\text { Description: The Traffic Message Channel (TMC) is a } \\
\text { technology for providing traffic and travel delay information to } \\
\text { drivers. The complementary Radio Data System (RDS) } \\
\text { broadcasts digital information carrying TMC updates via FM } \\
\text { radio waves. RDS-TMC is standardized under the EN ISO } \\
\text { 14819-series [ETSI 2011]. } \\
\text { Standard Type: Industry specification } \\
\text { Organization: Traveler Information Services Association } \\
\text { (TISA); ISO; European Committee for Standardization } \\
\text { Classification: Document format }\end{array}$ \\
\hline $\begin{array}{l}\text { Road Transport and Traffic } \\
\text { Telematics - Dedicate Short Range } \\
\text { Communication (DSRC) - DSRC } \\
\text { Application Layer }\end{array}$ & $\begin{array}{l}\text { Description: The standard specifies the application layer core, } \\
\text { which provides communication tools for applications based on } \\
\text { dedicated short range communication (DSRC) [ISO 2011c]. } \\
\text { Standard Type: ISO 15628: } 2007 \\
\text { Organization: ISO } \\
\text { Classification: Domain-specific integration interface }\end{array}$ \\
\hline
\end{tabular}




\begin{tabular}{|c|c|}
\hline $\begin{array}{l}\text { SARS Risk Assessment and } \\
\text { Preparedness Framework }\end{array}$ & $\begin{array}{l}\text { Description: This document sets out a framework of activities, } \\
\text { at national and international levels, that can be used to assess the } \\
\text { risk that SARS might recur and to prepare appropriate } \\
\text { contingency plans. Modeled on WHO’s influenza pandemic } \\
\text { preparedness plan, the framework adopts a phased approach in } \\
\text { which recommended activities escalate in line with the evolving } \\
\text { epidemiological situation. Phases are defined by distinct } \\
\text { epidemiological criteria, such as the detection of sporadic cases } \\
\text { with no secondary spread, the establishment of human-to-human } \\
\text { transmission, and evidence of international spread [WHO } \\
\text { 2011e]. } \\
\text { Standard Type: WHO/CDS/CSR/ARO/2004.2 } \\
\text { Organization: The World Health Organization (WHO) } \\
\text { Classification: Operational guidelines }\end{array}$ \\
\hline $\begin{array}{l}\text { Schema for Coverage Geometry and } \\
\text { Functions }\end{array}$ & $\begin{array}{l}\text { Description: The standard defines a conceptual schema for the } \\
\text { spatial characteristics of coverage, which support mapping from } \\
\text { a spatial, temporal or spatiotemporal domain to feature attribute } \\
\text { values where feature attribute types are common to all } \\
\text { geographic positions within the domain. A coverage domain } \\
\text { consists of a collection of direct positions in a coordinate space } \\
\text { that may be defined in terms of up to three spatial dimensions as } \\
\text { well as a temporal dimension [ISO 2011b]. } \\
\text { Standard Type: ISO 19123: } 2005 \\
\text { Organization: ISO } \\
\text { Classification: Domain-specific integration interface }\end{array}$ \\
\hline Sector-Specific Plans (SSPs) & $\begin{array}{l}\text { Description: Sector-Specific Plans (SSPs) have been developed } \\
\text { for each of the identified critical infrastructure sectors } \\
\text { supporting the National Infrastructure Protection Plan (NIPP). } \\
\text { The Sector-Specific Plans (SSPs) detail the application of the } \\
\text { National Infrastructure Protection Plan (NIPP) risk management } \\
\text { framework to the unique characteristics and risk landscape of } \\
\text { each sector and provide the means by which the NIPP is } \\
\text { implemented across all critical infrastructure and key resources } \\
\text { (CIKR) sectors. Each Sector-Specific Agency developed an SSP } \\
\text { through a coordinated effort involving their public and private } \\
\text { sector CIKR partners [DHS 2011b]. } \\
\text { Standard Type: The Sector-Specific Plans for Agriculture and } \\
\text { Food; Banking and Finance; Communications; Defense } \\
\text { Industrial Base; Energy; Information Technology; National } \\
\text { Monuments and Icons; Transportation Systems; and Water. } \\
\text { Organization: Department of Homeland Security } \\
\text { Classification: Operational guidelines }\end{array}$ \\
\hline SEDRIS Technologies & $\begin{array}{l}\text { Description: SEDRIS is an infrastructure technology that } \\
\text { enables information technology applications to express, } \\
\text { understand, share, and reuse environmental data. SEDRIS } \\
\text { technologies provide the means to represent environmental data }\end{array}$ \\
\hline
\end{tabular}




\begin{tabular}{|c|c|}
\hline & $\begin{array}{l}\text { (terrain, ocean, air, and space), and promote the unambiguous, } \\
\text { loss-less, and on-proprietary interchange of environmental data. } \\
\text { SEDRIS technologies have been assembled into the } \\
\text { specifications and associated language bindings that include: } \\
\text { SEDRIS functional specification, SEDRIS abstract transmittal } \\
\text { format, SEDRIS transmittal format binary encoding, SEDRIS } \\
\text { language binding, Spatial Reference Model (SRM), the } \\
\text { Environmental Data Coding Specification (EDCS), EDCS } \\
\text { language bindings, and SRM binding. Relies on its five core } \\
\text { technology components. These are the SEDRIS Data } \\
\text { Representation Model (DRM), the Environmental Data Coding } \\
\text { Specification (EDCS), the Spatial Reference Model (SRM), the } \\
\text { SEDRIS interface specification (API), and the SEDRIS } \\
\text { Transmittal Format (STF) [SEDRIS 2011a]. } \\
\text { Standard Type: ISO/IEC 18023-1; ISO/IEC 18023-2; ISO/IEC } \\
\text { 18023-3; ISO/IEC 18024-4; ISO/IEC 18025; ISO/IEC 18026; } \\
\text { ISO/IEC 18041-4; ISO/IEC 18042-4 } \\
\text { Organization: ISO/IEC; SEDRIS } \\
\text { Classification: Document format and Domain-specific } \\
\text { integration interface }\end{array}$ \\
\hline Shapefiles (.shp) & $\begin{array}{l}\text { Description: A shapefile stores non-topological geometry and } \\
\text { attribute information for the spatial features in a data set. The } \\
\text { geometry for a feature is stored as a shape comprising a set of } \\
\text { vector coordinates. A geospatial format provides users a } \\
\text { graphical method to display geographic data. Shapefiles are a } \\
\text { geospatial vector data format for geographic information } \\
\text { systems software. Shapefiles spatially describe points, polygons, } \\
\text { polylines. A “shapefile” commonly refers to a collection of files } \\
\text { with “.shp”, “.shx”, “.dbf”, and other extensions on a common } \\
\text { prefix name (i.e., “lakes.*”) [ESRI 2011a]. } \\
\text { Standard Type: Industry specification } \\
\text { Organization: Environmental Systems Research Institute } \\
\text { (ESRI) } \\
\text { Classification: Document format }\end{array}$ \\
\hline $\begin{array}{l}\text { Simple Transportation Management } \\
\text { Framework (STMF) }\end{array}$ & $\begin{array}{l}\text { Description: This standard describes the simple transportation } \\
\text { management framework used for managing and communicating } \\
\text { information between management stations and transportation } \\
\text { devices. It covers integrated management of transportation } \\
\text { networks, networking devices, and transportation specific } \\
\text { equipment attached to NTCIP-based networks [NTCIP 2011]. It } \\
\text { specifies a set of rules for processing, organizing and } \\
\text { exchanging information between transportation centers } \\
\text { (management applications) and transportation equipment (traffic } \\
\text { signal controllers, message signs, etc.) so they can communicate } \\
\text { with each other. } \\
\text { Standard Type: NTCIP 1101:1996; NTCIP } 1101 \text { Amendment } \\
1 \\
\text { Organization: American Association of State Highway and } \\
\text { Transportation Officials (AASHTO); Institute of }\end{array}$ \\
\hline
\end{tabular}




\begin{tabular}{|c|c|}
\hline & $\begin{array}{l}\text { Transportation Engineers (ITE); National Electrical } \\
\text { Manufacturers Association (NEMA) } \\
\text { Classification: Domain-specific integration interface }\end{array}$ \\
\hline $\begin{array}{l}\text { Simple Transportation Management } \\
\text { Framework (STMF) Application } \\
\text { Profile }\end{array}$ & $\begin{array}{l}\text { Description: This standard defines how to exchange data } \\
\text { between a management system and a field device with the } \\
\text { Simple Transportation Management Framework (STMF). This } \\
\text { standard includes mandatory requirements for implementing the } \\
\text { STMF, and optional and conditional requirements that may be } \\
\text { applicable in specific environments [NTCIP 2011]. } \\
\text { Standard Type: NTCIP 2301:2001 } \\
\text { Organization: American Association of State Highway and } \\
\text { Transportation Officials (AASHTO); Institute of Transportation } \\
\text { Engineers (ITE); National Electrical Manufacturers Association } \\
\text { (NEMA) } \\
\text { Classification: Domain-specific integration interface }\end{array}$ \\
\hline $\begin{array}{l}\text { Smallpox Response Plan and } \\
\text { Guidelines }\end{array}$ & $\begin{array}{l}\text { Description: This document outlines the public health strategies } \\
\text { that would guide the public health response to a smallpox } \\
\text { emergency and many of the federal, state, and local public } \\
\text { health activities that must be undertaken in a smallpox outbreak } \\
\text { [CDC 2011c]. } \\
\text { Standard Type: Smallpox Response Plan and Guidelines, } \\
\text { Version } 3.0 \\
\text { Organization: Centers for Disease Control and Prevention } \\
\text { (CDC) } \\
\text { Classification: Operational guidelines }\end{array}$ \\
\hline $\begin{array}{l}\text { Spatial Data Modeling Language } \\
\text { (SDML) }\end{array}$ & $\begin{array}{l}\text { Description: SDML format is very simple text, which provides } \\
\text { for easy parsing and support for attribute information [UWA } \\
\text { 2011]. } \\
\text { Standard Type: SDML } 1.0 \\
\text { Organization: Silicon Graphics } \\
\text { Classification: Domain-specific integration interface }\end{array}$ \\
\hline Spatial Referencing by Coordinates & $\begin{array}{l}\text { Description: The standard defines the conceptual schema for } \\
\text { the description of spatial referencing by coordinates, optionally } \\
\text { extended to spatio-temporal referencing. It describes the } \\
\text { minimum data required to define one-, two- and three- } \\
\text { dimensional spatial coordinate reference systems with an } \\
\text { extension to merged spatial-temporal reference systems. It } \\
\text { allows additional descriptive information to be provided. The } \\
\text { part } 2 \text { of the standard, ISO 19111-2:2009, specifies the } \\
\text { conceptual schema for the description of spatial referencing } \\
\text { using parametric values or functions. It applies the schema of } \\
\text { ISO } 19111 \text { to combine a position referenced by coordinates with } \\
\text { a parametric value to form a spatio-parametric coordinate } \\
\text { reference system (CRS). The spatio-parametric CRS can } \\
\text { optionally be extended to include time [ISO 2011b]. } \\
\text { Standard Type: ISO 19111: 2007; ISO 19111-2: } 2009\end{array}$ \\
\hline
\end{tabular}




\begin{tabular}{|c|c|}
\hline & $\begin{array}{l}\text { Organization: ISO } \\
\text { Classification: Domain-specific integration interface }\end{array}$ \\
\hline $\begin{array}{l}\text { Specification for } \\
\text { Telecommunications and Information } \\
\text { Exchange Between Roadside and } \\
\text { Vehicle Systems }\end{array}$ & $\begin{array}{l}\text { Description: This standard describes a medium access control } \\
\text { (MAC) and physical layer (PHY) specification for wireless } \\
\text { connectivity using dedicated short-range communications } \\
\text { (DSRC) services. DSRC provides the foundation for a variety of } \\
\text { applications including vehicle safety, automated tolling, } \\
\text { enhanced navigation, traffic management and many others } \\
\text { [ASTM 2011b]. } \\
\text { Standard Type: ASTM E2213-03 (2010) } \\
\text { Organization: ASTM International } \\
\text { Classification: Domain-specific integration interface }\end{array}$ \\
\hline $\begin{array}{l}\text { Specifications for Archiving ITS- } \\
\text { Generated Traffic Monitoring Data }\end{array}$ & $\begin{array}{l}\text { Description: This specification describes data elements and } \\
\text { schema for an archived data management system for intelligent } \\
\text { transportation system (ITS)-generated traffic monitoring data, } \\
\text { including conventional traffic monitoring data, data collected } \\
\text { directly from ITS systems, and travel-time data from probe } \\
\text { vehicles. It establishes the names of the data elements, their } \\
\text { interrelationships, and their procedural definitions. These } \\
\text { procedural definitions include data collection instrumentation } \\
\text { and methodology as well as recommended procedures for } \\
\text { calculating traffic statistics [ASTM 2011c]. } \\
\text { Standard Type: ASTM E2665-08 } \\
\text { Organization: ASTM International } \\
\text { Classification: Domain-specific integration interface }\end{array}$ \\
\hline $\begin{array}{l}\text { Standard Classifications for Incident } \\
\text { Reporting and Fire Protection Data }\end{array}$ & $\begin{array}{l}\text { Description: The specification provides a common language } \\
\text { and definitions for define and describe pre-incident } \\
\text { environments, fire, and other emergency incidents, post-incident } \\
\text { damage assessments, and fire service data [NFPA 2011]. } \\
\text { Standard Type: NFPA 901: } 2011 \\
\text { Organization: National Fire Protection Association (NFPA) } \\
\text { Classification: Domain-specific integration interface; } \\
\text { Operational guidelines }\end{array}$ \\
\hline $\begin{array}{l}\text { Standard for a Fire Service Vehicle } \\
\text { Operations Training Program }\end{array}$ & $\begin{array}{l}\text { Description: It specifies the minimum requirements for a fire } \\
\text { service vehicle operations training program (except for aircraft } \\
\text { and watercraft), including safety procedures for those members } \\
\text { who drive or occupy fire service vehicles [NFPA 2011]. } \\
\text { Standard Type: NFPA 1451: } 2007 \\
\text { Organization: National Fire Protection Association (NFPA) } \\
\text { Classification: Operational guidelines }\end{array}$ \\
\hline $\begin{array}{l}\text { Standard for a U.S. National Grid } \\
\text { (USNG) }\end{array}$ & $\begin{array}{l}\text { Description: A standard is used to define the U.S. National Grid } \\
\text { and supports Universal Transverse Mercator (UTM) } \\
\text { coordinates, Military Grid Reference System (MGRS) grids, and } \\
\text { the specific grid presentation requirements. It is used for } \\
\text { acquisition/production of printed map and acquisition of }\end{array}$ \\
\hline
\end{tabular}




\begin{tabular}{|c|c|}
\hline & $\begin{array}{l}\text { location service appliances with printed map products [FGDC } \\
\text { 2011e] } \\
\text { Standard Type: FGDC-STD-011-2001 } \\
\text { Organization: Federal Geographic Data Committee (FGDC) } \\
\text { Classification: Domain-specific integration interface }\end{array}$ \\
\hline $\begin{array}{l}\text { Standard for Installation, } \\
\text { Maintenance, and Use of Emergency } \\
\text { Services Communications Systems }\end{array}$ & $\begin{array}{l}\text { Description: The standard covers the installation, performance, } \\
\text { operation, and maintenance of public emergency services } \\
\text { communications systems and facilities [NFPA 2011]. } \\
\text { Standard Type: NFPA 1221: } 2010 \\
\text { Organization: National Protection Association (NFPA) } \\
\text { Classification: Operational guidelines }\end{array}$ \\
\hline $\begin{array}{l}\text { Standard on Disaster/Emergency } \\
\text { Management and Business } \\
\text { Continuity Programs }\end{array}$ & $\begin{array}{l}\text { Description: The standard provides a foundation for } \\
\text { disaster/emergency management planning and operations and } \\
\text { describes common elements, techniques, and processes [NFPA } \\
\text { 2011]. } \\
\text { Standard Type: NFPA 1600:2010 } \\
\text { Organization: National Fire Protection Association (NFPA) } \\
\text { Classification: Operational guidelines }\end{array}$ \\
\hline $\begin{array}{l}\text { Standard on Emergency Services } \\
\text { Incident Management System } \\
\text { Overview }\end{array}$ & $\begin{array}{l}\text { Description: The standard defines and describes the essential } \\
\text { elements of an incident management system that promotes } \\
\text { coordination among responding agencies [NFPA 2011]. } \\
\text { Standard Type: NFPA 1561:2008 } \\
\text { Organization: National Fire Protection Association (NFPA) } \\
\text { Classification: Domain-specific integration interface }\end{array}$ \\
\hline $\begin{array}{l}\text { Standard on Stored Electrical } \\
\text { Energy Emergency and Standby } \\
\text { Power Systems }\end{array}$ & $\begin{array}{l}\text { Description: This Standard presents performance requirements } \\
\text { for Level } 1 \text { and Level } 2 \text { stored electric energy systems providing } \\
\text { an alternate source of electrical power in buildings and facilities } \\
\text { in the event that the normal electrical power source fails. NFPA } \\
111 \text { also provides guidance for inspectors, designers, installers, } \\
\text { manufacturers, and users of a stored emergency power supply } \\
\text { system (SEPSS) and to serve as a basis for communication } \\
\text { between the parties involved. Systems covered include power } \\
\text { sources, transfer equipment, controls, supervisory equipment, } \\
\text { and accessory equipment needed to supply electrical power to } \\
\text { selected circuits [NFPA 2011]. } \\
\text { Standard Type: NFPA 111-2010 } \\
\text { Organization: National Fire Protection Association (NFPA) } \\
\text { Classification: Operational guidelines }\end{array}$ \\
\hline $\begin{array}{l}\text { Standard Representation of } \\
\text { Geographic Point Location by } \\
\text { Coordinates }\end{array}$ & $\begin{array}{l}\text { Description: The standard is a representation of latitude, } \\
\text { longitude and altitude for geographic point locations. The order } \\
\text { of the elements is the latitude, the longitude and the altitude. } \\
\text { Representation includes units of measure and coordinate order } \\
\text { [ISO 2011b]. } \\
\text { Standard Type: ISO 6709:2008 } \\
\text { Organization: ISO }\end{array}$ \\
\hline
\end{tabular}




\begin{tabular}{|c|c|}
\hline & Classification: Domain-specific integration interface \\
\hline $\begin{array}{l}\text { The Collaborative Design Activity } \\
\text { (COLLADA) }\end{array}$ & $\begin{array}{l}\text { Description: COLLADA is for establishing an open standard } \\
\text { digital asset schema for interactive 3D applications [COLLADA } \\
\text { 2011]. The schema supports all the features that modern 3D } \\
\text { interactive applications need including programmable shade } \\
\text { effects and physics simulation. } \\
\text { Standard Type: COLLADA 1.4.0 } \\
\text { Organization: The Khronos Group } \\
\text { Classification: Document format }\end{array}$ \\
\hline $\begin{array}{l}\text { The Health Level } 7 \text { (HL7) Arden } \\
\text { Syntax }\end{array}$ & $\begin{array}{l}\text { Description: This specification covers the sharing of } \\
\text { computerized health knowledge bases among personnel, } \\
\text { information systems, and institutions. The scope has been } \\
\text { limited to those knowledge bases that can be represented as a set } \\
\text { of discrete modules. Each module, referred to as a Medical } \\
\text { Logic Module (MLM), contains sufficient knowledge to make a } \\
\text { single decision. Contraindication alerts, management } \\
\text { suggestions, data interpretations, treatment protocols, and } \\
\text { diagnosis scores are examples of the health knowledge that can } \\
\text { be represented using MLMs. Each MLM also contains } \\
\text { management information to help maintain a knowledge base of } \\
\text { MLMs and links to other sources of knowledge. Health } \\
\text { personnel can create MLMs directly using this format, and the } \\
\text { resulting MLMs can be used directly by an information system } \\
\text { that conforms to this specification [HL7 2011a]. } \\
\text { Standard Type: ANSI/HL7 Arden V2.7-2008; ANSI/HL7 } \\
\text { Arden V2.6-2007; ANSI/HL7 Arden V2.5-2005; ANSI/HL7 } \\
\text { Arden V2.1-2002; ANSI/HL7 Arden V2.0-1999 } \\
\text { Organization: Health Level Seven International; ANSI } \\
\text { Classification: Domain-specific integration interface }\end{array}$ \\
\hline $\begin{array}{l}\text { The Health Level } 7 \text { (HL7) Clinical } \\
\text { Context Management (CCOW) }\end{array}$ & $\begin{array}{l}\text { Description: Aimed at facilitating the integration of } \\
\text { applications at the point of use, CCOW is an end-user-focused } \\
\text { standard that complements HL7’s traditional emphasis on data } \\
\text { interchange and enterprise workflow [HL7 2011b]. } \\
\text { Standard Type: CCOW Version 1.5; ANSI/HL7 CMS USPP, } \\
\text { R1-2008; ANSI/HL7 CMS CMPP, R1-2008; ANSI/HL7 CMS } \\
\text { APP, R1-2008 } \\
\text { Organization: Health Level Seven International; ANSI } \\
\text { Classification: Domain-specific integration interface }\end{array}$ \\
\hline $\begin{array}{l}\text { The Health Level } 7 \text { (HL7) V3 } \\
\text { Clinical Document Architecture } \\
\text { (CDA) }\end{array}$ & $\begin{array}{l}\text { Description: HL7 V3 Clinical Document Architecture (CDA) } \\
\text { allows for a common format for exchanging a patient's medical } \\
\text { record between different hospital systems or even different } \\
\text { hospitals. This HL7 standard has come to serve as a foundation } \\
\text { for the universal electronic medical record. It is an XML-based } \\
\text { markup standard intended to specify the encoding, structure and } \\
\text { semantics of clinical documents for exchange [HL7 2011c]. }\end{array}$ \\
\hline
\end{tabular}




\begin{tabular}{|c|c|}
\hline & $\begin{array}{l}\text { Standard Type: HL7 CDA Release 2.0; ANSI/HL7 CDA, R2- } \\
\text { 2005; ANSI/HL7 CDA, R1-2000 } \\
\text { Organization: Health Level Seven, Inc.; ANSI } \\
\text { Classification: Domain-specific integration interface }\end{array}$ \\
\hline $\begin{array}{l}\text { The Health Level } 7 \text { (HL7) Version } \\
\text { 2.x Messaging Standard }\end{array}$ & $\begin{array}{l}\text { Description: Health Level Seven (HL7) is an all-volunteer, non- } \\
\text { profit organization, involved in development of international } \\
\text { healthcare standards. HL7 version 2.x messaging standard } \\
\text { defines a series of electronic messages to support administrative, } \\
\text { logistical, financial and clinical processes. HL7 v2.x mostly uses } \\
\text { a proprietary (non-XML) encoding syntax based on delimiters. } \\
\text { HL7 v2.x has allowed for the interoperability between electronic } \\
\text { Patient Administration Systems (PAS), Electronic Practice } \\
\text { Management (EPM) systems, Laboratory Information Systems } \\
\text { (LIS), Dietary, Pharmacy and Billing systems as well as } \\
\text { Electronic Medical Record (EMR) or Electronic Health Record } \\
\text { (EHR) systems. Currently, HL7’s v2.x messaging standard is } \\
\text { supported by every major medical information systems vendor } \\
\text { in the United States [HL7 2011d]. } \\
\text { Standard Type: HL7 Version 2.6, HL7 Version 2.5.1; HL7 } \\
\text { Version 2.5, HL7 Version 2.4;HL7 Version 2.3.1;HL7 Version } \\
\text { 2.3 } \\
\text { Organization: Health Level Seven, Inc.; ANSI } \\
\text { Classification: Domain-specific integration interface }\end{array}$ \\
\hline $\begin{array}{l}\text { The Health Level } 7 \text { (HL7) Version } 3 \\
\text { Messaging Standard }\end{array}$ & $\begin{array}{l}\text { Description: The HL7 version } 3 \text { messaging standard is aimed to } \\
\text { support any and all healthcare workflows. The v3 standard, as } \\
\text { opposed to version 2, is based on a formal methodology and } \\
\text { object oriented principles. The Reference Information Model } \\
\text { (RIM) is the cornerstone of the HL7 Version } 3 \text { development } \\
\text { process and an essential part of the HL7 V3 development } \\
\text { methodology. The RIM expresses the data content needed in a } \\
\text { specific clinical or administrative context and provides an } \\
\text { explicit representation of the semantic and lexical connections } \\
\text { that exist between the information carried in the fields of HL7 } \\
\text { messages [HL7 2011e]. } \\
\text { Standard Type: HL7 Version } 3 \\
\text { Organization: Health Level Seven, Inc.; ANSI } \\
\text { Classification: Domain-specific integration interface }\end{array}$ \\
\hline $\begin{array}{l}\text { Topologically Integrated Geographic } \\
\text { Encoding and Referencing } \\
\text { /Geography Markup Language } \\
\text { (TIGER/GML) }\end{array}$ & $\begin{array}{l}\text { Description: A GML (an OGC specification for encoding } \\
\text { geographic features in XML) data format for TIGER } \\
\text { (Topologically Integrated Geographic Encoding and } \\
\text { Referencing) data is a standards-based alternative to the } \\
\text { TIGER/Line format. The TIGER/Line files are extracts of } \\
\text { selected geographic and cartographic information from the } \\
\text { Census Bureau's TIGER database. TIGER/GML data can be } \\
\text { viewed as JPEG, PNG, and TIFF images and SVG maps [OGC } \\
\text { 2011d]. } \\
\text { Standard Type: TIGER/GML v3.0 } \\
\text { Organization: Open Geospatial Consortium, Inc (OGC); U.S. }\end{array}$ \\
\hline
\end{tabular}




\begin{tabular}{|c|c|}
\hline & $\begin{array}{l}\text { Census Bureau } \\
\text { Classification: Domain-specific integration interface }\end{array}$ \\
\hline $\begin{array}{l}\text { Traffic and Travel Information (TTI) } \\
\text { - TTI via Transport Protocol Experts } \\
\text { Group (TPEG) Extensible Markup } \\
\text { Language }(X M L)\end{array}$ & $\begin{array}{l}\text { Description: ISO/TS 24530-1:2006 establishes the top-level } \\
\text { “containers” for TPEG messages in XML and the common data } \\
\text { types that are used by tpegML applications (e.g. tpeg-ptiML). } \\
\text { ISO/TS 24530-2:2006 establishes the XML encoding of the } \\
\text { method of Location Referencing used by TPEG applications. } \\
\text { ISO/TS 24530-3:2006 establishes the XML encoding of the } \\
\text { method of the Road Traffic Message application. ISO/TS } \\
\text { 24530-4:2006 establishes the XML encoding of the method of } \\
\text { the Public Transport Information application [ISO 2011b]. } \\
\text { Standard Type: ISO/TS 24530-1:2006; ISO/TS 24530-2:2006; } \\
\text { ISO/TS 24530-3:2006; ISO/TS 24530-4:2006 } \\
\text { Organization: ISO } \\
\text { Classification: Domain-specific integration interface }\end{array}$ \\
\hline $\begin{array}{l}\text { Traffic Management Center-to- } \\
\text { Center Communications }\end{array}$ & $\begin{array}{l}\text { Description: The standard for Traffic Management Center-to- } \\
\text { Center contains both a functional level data dictionary and a } \\
\text { message set and is designed to be independent of any specific } \\
\text { communications protocol. The data dictionary defines a set of } \\
\text { data elements (Des) necessary to support data exchange within } \\
\text { and among traffic management systems. Specifically, it provides } \\
\text { meta-attributes for each DE including definitions (semantics) } \\
\text { and specific format (syntax) [IHS 2011]. } \\
\text { Standard Type: AASHTO-ITE TM } 2.1 \\
\text { Organization: U.S. Department of Transportation (DOT) } \\
\text { Classification: Document format }\end{array}$ \\
\hline $\begin{array}{l}\text { Transit Communications Interface } \\
\text { Profiles (TCIP) }\end{array}$ & $\begin{array}{l}\text { Description: TCIP provides a library of information exchange } \\
\text { building blocks, to allow transit agencies and transit suppliers to } \\
\text { create standardized tailored interfaces [APTATCIP 2011]. The } \\
\text { Transit Communications Interface Profiles (TCIP) standard } \\
\text { specifies the rules and terms for the automated exchange of } \\
\text { information in transit applications such as operations, } \\
\text { maintenance, planning, management, and customer services. } \\
\text { TCIP is an interface standard whose primary purpose is to define } \\
\text { standardized mechanisms for the exchange of information in the } \\
\text { form of data among transit business systems, subsystems, } \\
\text { components, and devices. } \\
\text { Standard Type: APTA TCIP-S-01 3.0.3 } \\
\text { Organization: American Association of State Highway and } \\
\text { Transportation Officials (AASHTO); Institute of Transportation } \\
\text { Engineers (ITE); National Electrical Manufacturers Association } \\
\text { (NEMA) } \\
\text { Classification: Domain-specific integration interface }\end{array}$ \\
\hline $\begin{array}{l}\text { Transport information and control } \\
\text { systems - Traffic Impediment } \\
\text { Warning Systems (TIWS) - System }\end{array}$ & $\begin{array}{l}\text { Description: This standard specifies system requirements for } \\
\text { Traffic Impediment Warning Systems (TIWS). The purposes of } \\
\text { the warning system are that information collected by the }\end{array}$ \\
\hline
\end{tabular}




\begin{tabular}{|c|c|}
\hline Requirements & $\begin{array}{l}\text { infrastructure is automatically and quickly provided to vehicles } \\
\text { and reported to the traffic system operator, so vehicles can avoid } \\
\text { secondary accidents. This Technical Specification focuses on } \\
\text { closed circuit television (CCTV) cameras as the sensors, to } \\
\text { detect traffic impediments using image processing and variable } \\
\text { message signs as the communication method to provide } \\
\text { information to drivers [ISO 2011b]. } \\
\text { Standard Type: ISO/TS 15624:2001 } \\
\text { Organization: ISO } \\
\text { Classification: Operating guidelines }\end{array}$ \\
\hline $\begin{array}{l}\text { Transportation Management } \\
\text { Protocols (TMP) }\end{array}$ & $\begin{array}{l}\text { Description: This standard defines a set of rules and services for } \\
\text { exchanging transportation management information between } \\
\text { transportation management applications and equipment in an } \\
\text { interoperable manner. TMP defines a composite application } \\
\text { layer protocol for the management of transportation equipment. } \\
\text { The composite protocol consists of three component protocols: } \\
\text { the Internet-standard Simple Network Management Protocol } \\
\text { (SNMP), the Simple Fixed Message Protocol (SFMP), and the } \\
\text { Simple Transportation Management Protocol (STMP) [NTCIP } \\
\text { 2011]. } \\
\text { Standard Type: NTCIP 1103:2010 Version 02.17 } \\
\text { Organization: American Association of State Highway and } \\
\text { Transportation Officials (AASHTO); Institute of } \\
\text { Transportation Engineers (ITE); National Electrical } \\
\text { Manufacturers Association (NEMA) } \\
\text { Classification: Domain-specific integration interface }\end{array}$ \\
\hline Vector Product Format (VPF) & $\begin{array}{l}\text { Description: VPF is a standard format, structure, and } \\
\text { organization for large geographic databases that are based on a } \\
\text { georelational data model and are intended for direct use. VPF is } \\
\text { designed to be compatible with a wide variety of applications } \\
\text { and products. VPF allows application software to read data } \\
\text { directly from computer-readable media without } \\
\text { prior conversion to an intermediate form. VPF uses tables and } \\
\text { indexes that permit direct access by spatial location and thematic } \\
\text { content and is designed to be used with any digital geographic } \\
\text { data in vector format that can be represented using nodes, edges, } \\
\text { and faces [NGA 2011]. } \\
\text { Standard Type: MIL-STD-2407; MIL-STD-600006 } \\
\text { Organization: National Geospatial-Intelligence Agency (NGA) } \\
\text { Classification: Document format }\end{array}$ \\
\hline $\begin{array}{l}\text { Virtual Reality Modeling Language } \\
\text { (VRML) }\end{array}$ & $\begin{array}{l}\text { Description: VRML is a proposed design based on the Silicon } \\
\text { Graphics Open Inventor ASCII file format. VRML is a language } \\
\text { for describing multi-participant interactive simulations - virtual } \\
\text { worlds networked via the global Internet and hyper-linked with } \\
\text { the World Wide Web. All aspects of virtual world display, } \\
\text { interaction and internetworking can be specified using VRML. It } \\
\text { is the intention of its designers that VRML become the standard } \\
\text { language for interactive simulation within the World Wide Web }\end{array}$ \\
\hline
\end{tabular}




\begin{tabular}{|c|c|}
\hline & $\begin{array}{l}\text { [WEB3D 2011a]. } \\
\text { Standard Type: VRML } 1.0 \\
\text { Organization: Silicon Graphics, Inc. } \\
\text { Classification: Domain-specific integration interface }\end{array}$ \\
\hline Web Coverage Service (WCS) & $\begin{array}{l}\text { Description: Web Coverage Service (WCS) defines a standard } \\
\text { interface and operations that enables interoperable access to } \\
\text { geospatial coverage that refers to content such as satellite } \\
\text { images, digital aerial photos, digital elevation data, and other } \\
\text { phenomena represented by values at each measurement point } \\
\text { [OGC 2011e]. } \\
\text { Standard Type: OGC WCS } 2.0 \text { Interface Standard, WCS } \\
\text { Implementation Standard } 1.1 .2 \\
\text { Organization: The Open Geospatial Consortium, Inc (OGC) } \\
\text { Classification: Domain-specific integration interface }\end{array}$ \\
\hline Web Feature Service (WFS) & $\begin{array}{l}\text { Description: This specification describes the Web Feature } \\
\text { Service (WFS) operations. The WFS operations support } \\
\text { INSERT, UPDATE, DELETE, LOCK, QUERY and } \\
\text { DISCOVERY operations on geographic features using HTTP as } \\
\text { the distributed computing platform. In the context of this } \\
\text { specification, a transaction is a logical unit of work that is } \\
\text { composed of one or more data manipulation operations [OGC } \\
2011 \text { ]. } \\
\text { Standard Type: OpenGIS WFS Implementation Specification, } \\
\text { Version 1.1.0; OpenGIS WFS Interface Standard Version 2.0; } \\
\text { ISO 19142 } \\
\text { Organization: The Open Geospatial Consortium, Inc (OGC); } \\
\text { ISO } \\
\text { Classification: Domain-specific integration interface }\end{array}$ \\
\hline Web Map Service (WMS) & $\begin{array}{l}\text { Description: The specification provides a simple HTTP } \\
\text { interface for requesting geo-registered map images from one or } \\
\text { more distributed geospatial databases. A WMS request defines } \\
\text { the geographic layer(s) and area of interest to be processed. The } \\
\text { response to the request is one or more geo-registered map } \\
\text { images (returned as JPEG, PNG, etc) that can be displayed in a } \\
\text { browser application. The interface also supports the ability to } \\
\text { specify whether the returned images should be transparent so } \\
\text { that layers from multiple servers can be combined or not [OGC } \\
\text { 2011g]. } \\
\text { Standard Type: OpenGIS WMS Implementation Specification } \\
\text { Version 1.3.0; ISO 19128:2005 } \\
\text { Organization: The Open Geospatial Consortium, Inc. (OGC); } \\
\text { ISO } \\
\text { Classification: Document format }\end{array}$ \\
\hline$X 3 D$ & $\begin{array}{l}\text { Description: X3D is a royalty-free open standards file format } \\
\text { and run-time architecture to represent and communicate 3D } \\
\text { scenes and objects using XML. It is an ISO ratified standard that }\end{array}$ \\
\hline
\end{tabular}




\begin{tabular}{|l|l|}
\hline & $\begin{array}{l}\text { provides a system for the storage, retrieval and playback of real } \\
\text { time graphics content embedded in applications, all within an } \\
\text { open architecture to support a wide array of domains and user } \\
\text { scenarios [WEB3D 2011b]. }\end{array}$ \\
& Standard Type: ISO/IEC 19774:2006 (Humanoid Animation); \\
ISO/IEC 19775-1:2008 (Architecture and base components); \\
ISO/IEC 19775-2:2010 (Scene access interface); ISO/IEC \\
19776-1:2009 (XML encoding); NEN-ISO/IEC 19776-2:2008 \\
en (Classic VRML encoding); ISO/IEC 19776-3.2:2010 \\
(Compressed binary encoding); ISO/IEC 19777-1:2005 \\
(ECMAScript binding); ISO/IEC 19777-2:2006 (Java binding) \\
Organization: The Web3D Consortium \\
Classification: Document format
\end{tabular}

\subsubsection{Conceptual Modeling Standards}

\begin{tabular}{|l|l|}
\hline \multicolumn{1}{|c|}{ Standard Title } & \multicolumn{1}{|c|}{ Overview } \\
\hline $\begin{array}{l}\text { Discrete Event System Specification } \\
\text { (DEVS) }\end{array}$ & $\begin{array}{l}\text { Description: DEVS is a systems-theoretic approach to } \\
\text { modeling. More specifically, it is state-centered formalism. A } \\
\text { system consists of interconnected subsystems. A subsystem is a } \\
\text { system. Leaf systems (atomic DEVSes) are state machines. } \\
\text { DEVS can be viewed as a framework unifying a number of } \\
\text { other formalisms in a consistent, systems theoretic, state } \\
\text { centered fashion [DEVS 2011]. } \\
\text { Standard Type: Specification } \\
\text { Organization: Simulation Interoperability Standards } \\
\text { Organization (SISO); Society for Modeling and Computer } \\
\text { Simulation International (SCS) } \\
\text { Classification: Domain-specific integration interface }\end{array}$ \\
\hline $\begin{array}{l}\text { Systems Modeling Language } \\
\text { (SysML) }\end{array}$ & $\begin{array}{l}\text { Description: SysML is a general purpose modeling language for } \\
\text { systems engineering applications. It is a dialect of UML, the } \\
\text { industry standard for modeling software-intensive systems. It } \\
\text { supports the specification, analysis, design, verification and } \\
\text { validation of a broad range of systems and systems-of-systems. } \\
\text { These systems may include hardware, software, information, } \\
\text { processes, personnel, and facilities [OMG 2011]. } \\
\text { Standard Type: SysML 1.2 } \\
\text { Organization: Object Management Group, Inc. (OMG) } \\
\text { Classification: Document format }\end{array}$ \\
\hline Unified Modeling Language (UML) & $\begin{array}{l}\text { Description: A graphical language for visualizing, specifying, } \\
\text { constructing and documenting the artifacts of a software- } \\
\text { intensive system. The UML offers a standard way to write a } \\
\text { system's blueprints, including conceptual things such as } \\
\text { business processes and system functions, as well as concrete } \\
\text { things such as programming language statements, database } \\
\text { schemas, and reusable software components [ANSI 2011c]. }\end{array}$ \\
\hline
\end{tabular}




\begin{tabular}{|l|l|}
\hline & Standard Type: UML 2.0, UML 2.1.1; UML 2.1.2; UML 2.2; \\
UML 2.3; ISO/IEC 19501:2004 \\
Organization: ISO; ANSI; Object Management Group, Inc. \\
(OMG) \\
Classification: Document format
\end{tabular}

\subsubsection{Distributed Simulation Standards}

\begin{tabular}{|c|c|}
\hline Standard Title & Overview \\
\hline Distributed Interactive Simulation & $\begin{array}{l}\text { Description: Distributed Interactive Simulation (DIS) is a } \\
\text { government/industry initiative to define an infrastructure for } \\
\text { linking simulations of various types at multiple locations to } \\
\text { create realistic, complex, virtual worlds for the simulation of } \\
\text { highly interactive activities. A series of IEEE standards to } \\
\text { support information exchange between simulation applications } \\
\text { participating in the DIS environment are defined. IEEE Std } \\
\text { 1278.1 defines the format and semantics of data messages, also } \\
\text { known as Protocol Data Units (PDUs), that are exchanged } \\
\text { between simulation applications and simulation management. } \\
\text { IEEE Std 1278.2 defines the communication services required to } \\
\text { support the message exchange described in IEEE Std 1278.1. } \\
\text { IEEE 1278-3 provides guidelines for establishing a DIS } \\
\text { exercise, managing the exercise, and providing proper feedback. } \\
\text { IEEE 1278-4 establishes guidelines for the verification, } \\
\text { validation, and accreditation (VV\&A) of Distributed Interactive } \\
\text { Simulation (DIS) exercises [IHS 2011a]. } \\
\text { Standard Type: IEEE 1278-1993, IEEE 1278.1-1995, IEEE } \\
\text { 1278.1A-1998, IEEE-1278.2-1995, IEEE 1278.3-1996, IEEE } \\
\text { 1278.4-1997 } \\
\text { Organization: IEEE; IHS, Inc. } \\
\text { Classification: Domain-specific integration interface }\end{array}$ \\
\hline $\begin{array}{l}\text { Extensible Modeling and Simulation } \\
\text { Framework (XMSF) }\end{array}$ & $\begin{array}{l}\text { Description: The Extensible Modeling and Simulation } \\
\text { Framework (XMSF) is defined as a set of Web-based } \\
\text { technologies and services, applied within an extensible } \\
\text { framework, that enables a new generation of modeling \& } \\
\text { simulation (M\&S) applications to emerge, develop and } \\
\text { interoperate [DODCCRP 2011]. XMSF provides a framework } \\
\text { which allows both Department of Defense (DoD) and non-DoD } \\
\text { Modeling and Simulation (M\&S) projects to take advantage of } \\
\text { Web-based technologies. } \\
\text { Standard Type: XMSF 1.0 } \\
\text { Organization: Naval Postgraduate School MOVES Institute; } \\
\text { George Mason University NetLab; Science Applications } \\
\text { International Corporation; Old Dominion University } \\
\text { Classification: Domain-specific integration interface }\end{array}$ \\
\hline
\end{tabular}




\begin{tabular}{|l|l|}
\hline High Level Architecture (HLA) & $\begin{array}{l}\text { Description: This standard defines the HLA, its components, } \\
\text { and the rules that outline the responsibilities of HLA federates } \\
\text { and federations to ensure a consistent implementation [IEEE } \\
\text { 2011c]. } \\
\text { Standard Type: IEEE 1516-2000, IEEE 1516.1-2000, 1516.2- } \\
\text { 2000, ANSI/IEEE 1516.3-2003; IEEE 1516.4-2007 } \\
\text { Organization: IEEE/Simulation Interoperability Standards } \\
\text { Organization (SISO); ANSI } \\
\text { Classification: Domain-specific integration interface }\end{array}$ \\
\hline
\end{tabular}

\subsubsection{Selected Geographic Information System (GIS) Standards}

\begin{tabular}{|c|c|}
\hline Standard Title & Overview \\
\hline $\begin{array}{l}\text { CityGML - Exchange and Storage of } \\
\text { Virtual } 3 D \text { City Models }\end{array}$ & $\begin{array}{l}\text { Description: A standard for the representation, storage, and } \\
\text { exchange of virtual 3D city and landscape models. CityGML is } \\
\text { implemented as an application schema of the Geography } \\
\text { Markup Language version 3.1.1. It is based on a rich, general } \\
\text { purpose information model in additional to geometry and } \\
\text { appearance information. For specific domain areas, CityGML } \\
\text { also provides an extension mechanism to enrich the data with } \\
\text { identifiable features under preservation of semantic } \\
\text { interoperability [OGC 2011a]. } \\
\text { Standard Type: OGC 06-057r1; ISO TC211 } \\
\text { Organization: Open Geospatial Consortium, Inc. (OGC) } \\
\text { Classification: Domain-specific integration interface }\end{array}$ \\
\hline $\begin{array}{l}\text { American National Standard for } \\
\text { Information Technology - } \\
\text { Geographical Information Systems - } \\
\text { Spatial Data Standard for Facilities, } \\
\text { Infrastructure, and Environment } \\
\text { (SDSFIE) }\end{array}$ & $\begin{array}{l}\text { Description: This standard provides a means to model and } \\
\text { categorize real-world geographic phenomena of interest to the } \\
\text { Facilities, Infrastructure, and Environment (FIE) Domain(s) into } \\
\text { a set of geographic data that can be represented in a spatial } \\
\text { database and presented to a user in digital form. This SDSFIE } \\
\text { standard is intended to provide the enterprise spatial database } \\
\text { schema to support multiple FIE applications. This National } \\
\text { Standard is applicable to the federal, state, county, and city } \\
\text { agencies; private companies; and any other organizations that } \\
\text { perform AM \& FM functions for facilities and other types of } \\
\text { infrastructure (such as roads, waterways, utility systems, etc,) } \\
\text { and/or perform environmental compliance, restoration, and/or } \\
\text { pollution prevention activities [ANSI 2011a]. } \\
\text { Standard Type: ANSI INCITS 353-2006 } \\
\text { Organization: American National Standards Institute (ANSI); } \\
\text { International Committee for Information Technology Standards } \\
\text { (INCITS) } \\
\text { Classification: Domain-specific integration interface }\end{array}$ \\
\hline $\begin{array}{l}\text { Content Standard for Digital } \\
\text { Geospatial Metadata (CSDGM) }\end{array}$ & $\begin{array}{l}\text { Description: The standard is often referred to as the FGDC } \\
\text { Metadata Standard. The objectives of the standard are to } \\
\text { provide a common set of terminology and definitions for the }\end{array}$ \\
\hline
\end{tabular}




\begin{tabular}{|c|c|}
\hline & $\begin{array}{l}\text { documentation of digital geospatial data. The standard } \\
\text { establishes the names of data elements and compound elements } \\
\text { (groups of data elements) to be used for these purposes, the } \\
\text { definitions of these compound elements and data elements, and } \\
\text { information about the values that are to be provided for the data } \\
\text { elements [FGDC 2011a]. } \\
\text { Standard Type: FGDC-STD-001-1998; FGDC-STD-001.1- } \\
\text { 1999; FGDC-STD-001.2-2001 } \\
\text { Organization: Federal Geographic Data Committee (FGDC) } \\
\text { Classification: Domain-specific integration interface }\end{array}$ \\
\hline $\begin{array}{l}\text { Content Standard for Digital } \\
\text { Geospatial Metadata (CSDGM) - } \\
\text { Extensions for Remote Sensing } \\
\text { Metadata }\end{array}$ & $\begin{array}{l}\text { Description: The standard of Extensions for Remote Sensing } \\
\text { Metadata standard provides a common terminology and set of } \\
\text { definitions for documenting geospatial data obtained from } \\
\text { remote sensing, within the framework of the FGDC Content } \\
\text { Standard for Digital Geospatial Metadata (CSDGM) standard. } \\
\text { The extensions provide a means to use standard FGDC content } \\
\text { to describe geospatial data derived from remote sensing } \\
\text { measurements. This standard is intended to support the } \\
\text { collection and processing of geospatial metadata for data derived } \\
\text { from remote sensing. It is intended to be used by all levels of } \\
\text { government and the private sector [FGDC 2011b]. } \\
\text { Standard Type: FGDC-STD-012-2002 } \\
\text { Organization: The Federal Geographic Data Committee } \\
\text { (FGDC) } \\
\text { Classification: Domain-specific integration interface }\end{array}$ \\
\hline GeoAPI SWG Standard & $\begin{array}{l}\text { Description: The GeoAPI Standard Working Group (SWG) } \\
\text { aims to create the GeoAPI 3.0 Standard, which will define a set } \\
\text { of Java language interfaces along with an associated test suite, to } \\
\text { provide a standardized, programming language level realization } \\
\text { of some core Open Geospatial Consortium (OGC) } \\
\text { specifications. These interfaces will facilitate the creation of } \\
\text { accurate, coherent, interoperable, and verifiable implementations } \\
\text { of those OGC standards [GEOAPI 2011]. } \\
\text { Standard Type: OGC GeoAPI 3.0 SWG } \\
\text { Organization: OGC } \\
\text { Classification: Domain-specific integration interface }\end{array}$ \\
\hline Geographic Information - Encoding & $\begin{array}{l}\text { Description: The standard specifies the requirements for } \\
\text { defining encoding rules to be used for interchange of geographic } \\
\text { data within the ISO } 19100 \text { series of International Standards [ISO } \\
\text { 2011b]. } \\
\text { Standard Type: ISO 19118:2005 } \\
\text { Organization: ISO } \\
\text { Classification: Domain-specific integration interface }\end{array}$ \\
\hline $\begin{array}{l}\text { Geographic Information - Location- } \\
\text { Based Services - Multimodal } \\
\text { Routing and Navigation }\end{array}$ & $\begin{array}{l}\text { Description: The standard specifies the data types and their } \\
\text { associated operations for the implementation of multimodal } \\
\text { location-based services for routing and navigation. It is designed }\end{array}$ \\
\hline
\end{tabular}




\begin{tabular}{|c|c|}
\hline & $\begin{array}{l}\text { to specify web services that may be made available to wireless } \\
\text { devices through web-resident proxy applications, but is not } \\
\text { limited to that environment [ISO 2011b]. } \\
\text { Standard Type: ISO 19134:2007 } \\
\text { Organization: ISO } \\
\text { Classification: Domain-specific integration interface }\end{array}$ \\
\hline $\begin{array}{l}\text { Geographic Information - Location- } \\
\text { Based Services - Tracking and } \\
\text { Navigation }\end{array}$ & $\begin{array}{l}\text { Description: ISO 19133:2005 describes the data types, and } \\
\text { operations associated with those types, for the implementation } \\
\text { of tracking and navigation services. It is designed to specify web } \\
\text { services that can be made available to wireless devices through } \\
\text { web-resident proxy applications, but is not restricted to that } \\
\text { environment [ISO 2011b]. } \\
\text { Standard Type: ISO 19133:2005 } \\
\text { Organization: ISO } \\
\text { Classification: Domain-specific integration interface }\end{array}$ \\
\hline Geographic Information - Portrayal & $\begin{array}{l}\text { Description: The standard defines a schema describing the } \\
\text { portrayal of geographic information in a form understandable by } \\
\text { humans. It includes the methodology for describing symbols and } \\
\text { mapping of the schema to an application schema. It does not } \\
\text { include standardization of cartographic symbols, and their } \\
\text { geometric and functional description [ISO 2011b]. } \\
\text { Standard Type: ISO 19117:2005 } \\
\text { Organization: ISO } \\
\text { Classification: Domain-specific integration interface }\end{array}$ \\
\hline $\begin{array}{l}\text { Geographic Information - } \\
\text { Procedures for Item Registration }\end{array}$ & $\begin{array}{l}\text { Description: ISO 19135:2005 specifies procedures to be } \\
\text { followed in establishing, maintaining and publishing registers of } \\
\text { unique, unambiguous and permanent identifiers, and meanings } \\
\text { that are assigned to items of geographic information. In order to } \\
\text { accomplish this purpose, ISO 19135:2005 specifies elements of } \\
\text { information that are necessary to provide identification and } \\
\text { meaning to the registered items and to manage the registration of } \\
\text { these items [ISO 2011b]. } \\
\text { Standard Type: INCITS/ISO/IEC 19135-2005 } \\
\text { Organization: ISO; International Committee for Information } \\
\text { Technology Standards (INCITS); International Electrotechnical } \\
\text { Commission (IEC) } \\
\text { Classification: Domain-specific integration interface }\end{array}$ \\
\hline $\begin{array}{l}\text { Geographic Information - Schema } \\
\text { for Moving Features }\end{array}$ & $\begin{array}{l}\text { Description: The standard defines a method to describe the } \\
\text { geometry of a feature that moves as a rigid body [ISO 2011b]. } \\
\text { Standard Type: ISO 19141:2008 } \\
\text { Organization: ISO } \\
\text { Classification: Domain-specific integration interface }\end{array}$ \\
\hline Geographic Information - Services & $\begin{array}{l}\text { Description: ISO 19119:2005 identifies and defines the } \\
\text { architecture patterns for service interfaces used for geographic } \\
\text { information, defines its relationship to the Open Systems }\end{array}$ \\
\hline
\end{tabular}




\begin{tabular}{|c|c|}
\hline & $\begin{array}{l}\text { Environment model, presents a geographic services taxonomy } \\
\text { and a list of example geographic services placed in the services } \\
\text { taxonomy. It also prescribes how to create a platform-neutral } \\
\text { service specification, how to derive conformant platform- } \\
\text { specific service specifications, and provides guidelines for the } \\
\text { selection and specification of geographic services from both } \\
\text { platform-neutral and platform-specific perspectives [ISO } \\
\text { 2011b]. } \\
\text { Standard Type: INCITS/ISO 19119-2005 } \\
\text { Organization: ISO; International Committee for Information } \\
\text { Technology Standards (INCITS) } \\
\text { Classification: Domain-specific integration interface }\end{array}$ \\
\hline $\begin{array}{l}\text { Geographic Information - Simple } \\
\text { Feature Access }\end{array}$ & $\begin{array}{l}\text { Description: ISO 19125-1:2004 establishes a common } \\
\text { architecture for geographic information and defines terms to use } \\
\text { within the architecture. It also standardizes names and geometric } \\
\text { definitions for Types for Geometry. INCITS/ISO 19125-2-2004 } \\
\text { specifies an Structured Query Language (SQL) schema that } \\
\text { supports storage, retrieval, query and update of simple } \\
\text { geospatial feature collections via the SQL Call Level Interface } \\
\text { (SQL/CLI) and establishes an architecture for the } \\
\text { implementation of feature tables. INCITS/ISO 19125-2-2004 } \\
\text { defines terms to use within the architecture. Of geographic } \\
\text { information and defines a simple feature profile of ISO 19107. } \\
\text { In addition, this part of ISO 19125:2004 describes a set of SQL } \\
\text { Geometry Types together with SQL functions on those types. } \\
\text { The Geometry Types and Functions described represent a profile } \\
\text { of ISO 13249-3. INCITS/ISO 19125-2-2004 standardizes the } \\
\text { names and geometric definitions of the SQL Types for } \\
\text { Geometry and the names, signatures and geometric definitions } \\
\text { of the SQL Functions for Geometry [ISO 2011b]. } \\
\text { Standard Type: INCITS/ISO 19125-1-2004 ; INCITS/ISO } \\
\text { 19125-2-2004 } \\
\text { Organization: ISO; International Committee for Information } \\
\text { Technology Standards (INCITS) } \\
\text { Classification: Domain-specific integration interface }\end{array}$ \\
\hline $\begin{array}{l}\text { Geographic Information Framework } \\
\text { Data Standard }\end{array}$ & $\begin{array}{l}\text { Description: The standard establishes common data } \\
\text { requirements for the exchange of National Spatial Data } \\
\text { Infrastructure (NSDI) framework data [FGDC 2011c]. } \\
\text { Standard Type: FGDC-STD-014.0-2008; FGDC-STD-014.1- } \\
\text { 2008; FGDC-STD-014.2-2008; FGDC-STD-014.3-2008; } \\
\text { FGDC-STD-014.4-2008; FGDC-STD-014.5-2008; FGDC-STD- } \\
\text { 014.6-2008; FGDC-STD-014.7-2008; FGDC-STD-014.7b- } \\
\text { 2008; FGDC-STD-014.7c-2008; FGDC-STD-014.7d-2008; } \\
\text { FGDC-STD-014.7e-2008 } \\
\text { Organization: Federal Geographic Data Committee (FGDC) } \\
\text { Classification: Domain-specific integration interface }\end{array}$ \\
\hline GeoTIFF & $\begin{array}{l}\text { Description: GeoTIFF is a metadata format, which provides } \\
\text { geographic information to associate with the image data. }\end{array}$ \\
\hline
\end{tabular}




\begin{tabular}{|c|c|}
\hline & $\begin{array}{l}\text { GeoTIFF implements the geographic metadata formally, using } \\
\text { compliant Tagged Image File (TIFF 6.0) tags and structures. } \\
\text { "GeoTIFF" refers to TIFF files, which have geographic (or } \\
\text { cartographic) data embedded as tags within the TIFF file. The } \\
\text { geographic data can then be used to position the image in the } \\
\text { correct location and geometry on the screen of a geographic } \\
\text { information display [GEOTIFF 2011]. } \\
\text { Standard Type: GeoTIFF/Revision } 1.0 \\
\text { Organization: geotiff.osgeo.org } \\
\text { Classification: Document format }\end{array}$ \\
\hline $\begin{array}{l}\text { Governmental Unit and Other } \\
\text { Geographic Area Boundaries }\end{array}$ & $\begin{array}{l}\text { Description: A specification for establishing of content } \\
\text { requirements for the collection and interchange of Government } \\
\text { units and legal entity boundary data and for facilitating the } \\
\text { maintenance and use of that information [FGDC 2010]. } \\
\text { Standard Type: FGDC-STD-014.5-2008 } \\
\text { Organization: Federal Geographic Data Committee (FGDC) } \\
\text { Classification: Domain-specific Integration Interfaces }\end{array}$ \\
\hline GRIdded Binary (GRIB) & $\begin{array}{l}\text { Description: Format specifications for representing } \\
\text { meteorological, gridded-point data [WMO 2010a]. } \\
\text { Standard Type: FM 92-IX Ext. GRIB; FM 92-VIII EXT. GRIB } \\
\text { Organization: World Meteorological Organization (WMO) } \\
\text { Classification: Domain-specific Integration Interfaces }\end{array}$ \\
\hline $\begin{array}{l}\text { Homeland Security Mapping } \\
\text { Standard - Point Symbology for } \\
\text { Emergency Management }\end{array}$ & $\begin{array}{l}\text { Description: The primary purpose of this standard is to } \\
\text { establish a common set of symbols for use by mapmakers in } \\
\text { support of emergency managers and first responders. It will } \\
\text { allow users to rapidly interpret map data and to be able to } \\
\text { disseminate consistent, usable information. This American } \\
\text { National Standard is applicable to all organizations that create } \\
\text { maps or otherwise display features for the Emergency } \\
\text { Management or First Responder communities. It is limited at } \\
\text { this time to support portrayal of point features that relate to the } \\
\text { emergency management and hazard mapping disciplines [ANSI } \\
\text { 2011b]. } \\
\text { Standard Type: ANSI INCITS 415-2006 } \\
\text { Organization: American National Standards Institute (ANSI); } \\
\text { International Committee for Information Technology Standards } \\
\text { (INCITS) } \\
\text { Classification: Domain-specific integration interface }\end{array}$ \\
\hline $\begin{array}{l}\text { OpenGIS Implementation } \\
\text { Specification for Geographic } \\
\text { Information - Simple Feature Access }\end{array}$ & $\begin{array}{l}\text { Description: The OpenGIS Simple Features Interface Standard } \\
\text { (SFS) provides a well-defined and common way for applications } \\
\text { to store and access feature data in relational or object-relational } \\
\text { databases, so that the data can be used to support other } \\
\text { applications through a common feature model, data store and } \\
\text { information access interface. OpenGIS Simple Features are } \\
\text { geospatial features described using vector data elements such as } \\
\text { points, lines, and polygons [OGC 2011c]. }\end{array}$ \\
\hline
\end{tabular}




\begin{tabular}{|l|l|}
\hline $\begin{array}{l}\text { Spatial Data Transfer Standard } \\
\text { (SDTS) }\end{array}$ & $\begin{array}{l}\text { Standard Type: OGC 06-103r4 Version 1.2.1, OGC 05-126 } \\
\text { Organization: Open Geospatial Consortium, Inc (OGC) } \\
\text { Classification: Domain-specific integration interface }\end{array}$ \\
$\begin{array}{l}\text { Description: The Spatial Data Transfer Standard (SDTS) base } \\
\text { specification (Parts 1, 2 and 3) describes the underlying } \\
\text { conceptual model and the detailed specifications for the content, } \\
\text { structure, and format for exchange of spatial data. Additional } \\
\text { parts (4, 5, 6 and potentially others) are added as profiles, each } \\
\text { of which defines specific rules and formats for applying SDTS } \\
\text { for the exchange of particular types of data [FGDC 2011d] } \\
\text { Standard Type: FGDC-STD-002.1; FGDC-STD-002.5; FGDC- } \\
\text { STD-002.6; FGDC-STD-002.7-2000 } \\
\text { Organization: Federal Geographic Data Committee (FGDC) } \\
\text { Classification: Domain-specific integration interface }\end{array}$ \\
\hline $\begin{array}{l}\text { Standard for a U.S. National Grid } \\
\text { (USNG) }\end{array}$ & $\begin{array}{l}\text { Description: A standard is used to define the U.S. National Grid } \\
\text { and supports Universal Transverse Mercator (UTM) } \\
\text { coordinates, Military Grid Reference System (MGRS) grids, and } \\
\text { the specific grid presentation requirements. It is used for } \\
\text { acquisition/production of printed map and acquisition of } \\
\text { location service appliances with printed map products [FGDC } \\
\text { 2011e] } \\
\text { Standard Type: FGDC-STD-011-2001 } \\
\text { Organization: Federal Geographic Data Committee (FGDC) } \\
\text { Classification: Domain-specific integration interface }\end{array}$ \\
\hline
\end{tabular}

\subsubsection{Selected Communication Standards}

\begin{tabular}{|l|l|}
\hline \multicolumn{1}{|c|}{ Standard Title } & \multicolumn{1}{|c|}{ Overview } \\
\hline Common Alerting Protocol (CAP) & $\begin{array}{l}\text { Description: The Common Alerting Protocol (CAP) is a simple, } \\
\text { flexible data interchange format for collecting and distributing } \\
\text { "all-hazard" safety notifications and emergency warnings over } \\
\text { information networks and public alerting systems. In Web- } \\
\text { services applications, CAP provides a lightweight standard for } \\
\text { exchanging urgent notifications. CAP can also be used in data- } \\
\text { broadcast applications and over legacy data networks. CAP is } \\
\text { fully compatible with the existing national broadcast Emergency } \\
\text { Alert System (EAS) [OASIS 2011a]. It is an XML-related data } \\
\text { interchange standard for alerting and event notification } \\
\text { applications. The standard supports two functions: a standalone } \\
\text { protocol and a payload for Emergency Data Exchange Language } \\
\text { (EDXL) messages [OASIS 2011b]. } \\
\text { Standard Type: CAP-V1.1 } \\
\text { Organization: Organization for the Advancement of Structured } \\
\text { Information Standards (OASIS) } \\
\text { Classification: Domain-specific integration interface }\end{array}$ \\
\hline
\end{tabular}




\begin{tabular}{|c|c|}
\hline $\begin{array}{l}\text { Emergency Data Exchange } \\
\text { Language (EDXL) }\end{array}$ & $\begin{array}{l}\text { Description: Several organizations are collaborating on the } \\
\text { design and development of a suite of specifications under the } \\
\text { name “Emergency Data Exchange Language (EDXL)” [OASIS } \\
\text { 2011b]. EDXL is an integrated framework for a wide range of } \\
\text { emergency data exchange standards to support operations, } \\
\text { logistics, planning, and finance. } \\
\text { Standard Type: EXDL Distribution Element, V. 1.0 (EDXL- } \\
\text { DE-V1.0); EDXL Resource Message Specification 1.0 Working } \\
\text { Draft Version 26 (EDXL-RM 1.0 v0026); EDXL Hospital } \\
\text { Availability Exchange v1.0 Public Review Draft 02 (EDXL- } \\
\text { HAVE-1.0-spec-pr02) } \\
\text { Organization: Organization for the Advancement of Structured } \\
\text { Information Standards (OASIS); Department of Homeland } \\
\text { Security (DHS); Emergency Interoperability Consortium (EIC) } \\
\text { Classification: Domain-specific integration interface }\end{array}$ \\
\hline $\begin{array}{l}\text { National Information Exchange } \\
\text { Model (NIEM) }\end{array}$ & $\begin{array}{l}\text { Description: NIEM is designed to develop, disseminate and } \\
\text { support enterprise-wide information exchange standards and } \\
\text { processes that can enable jurisdictions to effectively share } \\
\text { critical information in emergency situations, as well as support } \\
\text { the day-to-day operations of agencies throughout the nation } \\
\text { [NIEM 2011]. } \\
\text { Organization: A partnership of the U.S. Department of Justice, } \\
\text { the U.S. Department of Homeland Security, and the U.S. } \\
\text { Department of Health and Human Services. } \\
\text { Classification: Domain-specific integration interface }\end{array}$ \\
\hline
\end{tabular}

\subsection{Data Sources}

This section identifies databases and other sources of data that may be used to develop or run CIKR models and simulations. The name of data source, a brief description of its contents, its access location, responsible organization, data formats used, as well a classification of the type of data is given below.

\begin{tabular}{|c|c|}
\hline Data Source Title & Overview \\
\hline American Community Survey (ACS) & $\begin{array}{l}\text { Description: The American Community Survey (ACS) is a } \\
\text { nationwide survey designed to provide communities a fresh } \\
\text { look at how they are changing. It is a critical element in the } \\
\text { Census Bureau's reengineered decennial census program. The } \\
\text { ACS collects and produces population and housing information } \\
\text { every year instead of every ten years. The ACS FTP Site } \\
\text { contains data from the American Community Survey as they } \\
\text { are released. The FTP site contains data tables from all years } \\
\text { of the ACS, Public Use Microdata Sample (PUMS) Files, the } \\
\text { ACS Summary Files, table shells, archived from the 1996 - } \\
2004 \text { ACS, and more [CENSUS 2011b]. } \\
\text { Data Source: ACS FTP Site } \\
\text { Organization: U.S. Census Bureau (USCS) } \\
\text { Format Used: PDF; Excel } \\
\text { Classification: Demographic and Behavioral }\end{array}$ \\
\hline
\end{tabular}




\begin{tabular}{|c|c|}
\hline American FactFinder & $\begin{array}{l}\text { Description: The American FactFinder, an on-line tool, } \\
\text { provides data in the form of maps, tables, and reports from a } \\
\text { variety of Census Bureau sources. Information provided by the } \\
\text { American FactFinder includes basic demographic; social and } \\
\text { economic data; popular statistics tables on people, housing, and } \\
\text { business and government; censuses and surveys; etc. The } \\
\text { Census Bureau conducts many censuses and surveys. The most } \\
\text { well-known is the official population census of the United } \\
\text { States, called the decennial census. It is conducted every ten } \\
\text { years, most recently in April 2010. During each decennial } \\
\text { census, the Census Bureau collects data from every household } \\
\text { in the U.S. and its territories [CENSUS 2011c]. } \\
\text { Data Source: American FactFinder } \\
\text { Organization: U.S. Census Bureau } \\
\text { Format Used: Shapefile; Excel; ASCII } \\
\text { Classification: Demographic and Behavioral }\end{array}$ \\
\hline $\begin{array}{l}\text { American Hospital Association (AHA) } \\
\text { Database }\end{array}$ & $\begin{array}{l}\text { Description: American Hospital Association (AHA) Database } \\
\text { contains data for every hospital in the U.S. The data is collected } \\
\text { from AHA annually survey. Non-responding hospital data are } \\
\text { estimated using advanced methods to approximate specific data } \\
\text { elements. The AHA Annual Survey Database for Fiscal Year } \\
2009 \text { has more than } 700 \text { fields of data and information on } \\
\text { 6,000+ hospitals. Included in the database are demographic } \\
\text { information, organizational structure, facilities and services, } \\
\text { utilization data, community orientation indicators, physician } \\
\text { arrangements, managed care relationships, expenses and } \\
\text { staffing [AHADATA 2011]. } \\
\text { Data Source: American Hospital Association (AHA) } \\
\text { Database; Hospital Detail Report Wizard; Hospital Market } \\
\text { Analysis Wizard; Healthcare Systems and Networks Report } \\
\text { Wizard } \\
\text { Organization: American Hospital Association (AHA) } \\
\text { Format Used: Excel; ASCII; PDF } \\
\text { Classification: Resources; Demographic and Behavioral }\end{array}$ \\
\hline $\begin{array}{l}\text { American Hospital Directory's Data } \\
\text { Services }\end{array}$ & $\begin{array}{l}\text { Description: The American Hospital Directory (AHD) } \\
\text { provides data and statistics about more than 6,000 hospitals } \\
\text { nationwide. The database of information about hospitals is built } \\
\text { from both public and private sources including Medicare claims } \\
\text { data, hospital cost reports, and other files obtained from the } \\
\text { federal Centers for Medicare and Medicaid Services (CMS). } \\
\text { AHD is not affiliated with the American Hospital Association } \\
\text { and is not a source for AHA Data. Users use their search tools } \\
\text { to explore their database of hospital information. Key statistics } \\
\text { may be summarized by hospital, state, and nation. Statistics } \\
\text { include bed size, discharges, patient days, and gross patient } \\
\text { revenue [AHD 2011]. } \\
\text { Data Source: AHD's Data Services, AHD’s Quick Search; } \\
\text { AHD's Advanced Search }\end{array}$ \\
\hline
\end{tabular}




\begin{tabular}{|c|c|}
\hline & $\begin{array}{l}\text { Organization: American Hospital Directory (AHD) } \\
\text { Format Used: .CSV; ASCII; Excel } \\
\text { Classification: Resources; Demographic and Behavioral }\end{array}$ \\
\hline American Housing Survey (AHS) & $\begin{array}{l}\text { Description: The American Housing Survey (AHS) collects } \\
\text { data on the Nation's housing, including apartments, single- } \\
\text { family homes, mobile homes, vacant housing units, household } \\
\text { characteristics, income, housing and neighborhood quality, } \\
\text { housing costs, equipment and fuels, size of housing unit, and } \\
\text { recent movers. National data are collected in odd numbered } \\
\text { years, and data for each of } 47 \text { selected Metropolitan Areas are } \\
\text { collected currently about every six years. The national sample } \\
\text { covers an average 55,000 housing units. Each metropolitan area } \\
\text { sample covers 4,100 or more housing units. The survey is } \\
\text { conducted by the Bureau of the Census for the Department of } \\
\text { Housing and Urban Development (HUD). The Data Access } \\
\text { includes three categories: National Data, Metropolitan Data, } \\
\text { and Dates metropolitan Areas are Surveyed [CENSUS 2011d]. } \\
\text { Data Source: AHS Data Access } \\
\text { Organization: U.S. Census Bureau (USCS) } \\
\text { Format Used: Excel; PDF } \\
\text { Classification: Demographic and Behavioral }\end{array}$ \\
\hline $\begin{array}{l}\text { Automated Critical Asset } \\
\text { Management System (ACAMS) }\end{array}$ & $\begin{array}{l}\text { Description: Automated Critical Asset Management System } \\
\text { (ACAMS) is a web-enabled information services portal that } \\
\text { helps state and local governments build CIKR protection } \\
\text { programs in their local jurisdictions. ACAMS is a secure, } \\
\text { online database, and database management platform that allows } \\
\text { for the collection and management of CIKR asset data; the } \\
\text { cataloguing, screening, and sorting of this data; the production } \\
\text { of tailored infrastructure reports; and the development of a } \\
\text { variety of pre- and post-incident response plans useful to } \\
\text { strategic and operational planners and tactical commanders } \\
\text { [DHS 2011c]. } \\
\text { Data Source: ACAMS } \\
\text { Organization: Department of Homeland Security/Office of } \\
\text { Infrastructure Protection } \\
\text { Format Used: TXT; PDF; Keyhole Markup Language (KML) } \\
\text { Classification: Resources; Controlling Documents }\end{array}$ \\
\hline ChicagoMaps & $\begin{array}{l}\text { Description: ChicagoMaps provides information on citizen } \\
\text { services and physical infrastructure components in the city. } \\
\text { Geographic Information Systems (GIS) is used to manage street } \\
\text { and building inventories, dispatch services, and maintenance of } \\
\text { underground utilities [CHICAGO 2011]. } \\
\text { Data Source: Chicago GIS Portal } \\
\text { Organization: City of Chicago } \\
\text { Format Used: GIF } \\
\text { Classification: Resources; Spatial }\end{array}$ \\
\hline
\end{tabular}




\begin{tabular}{|c|c|}
\hline $\begin{array}{l}\text { Community Collaborative Rain, Hail } \\
\text { and Snow Observations (CoCoRaHS) } \\
\text { Reports }\end{array}$ & $\begin{array}{l}\text { Description: The National Weather Service (NWS) supports } \\
\text { the Community Collaborative Rain, Hail and Snow } \\
\text { (CoCoRaHS) network. CoCoRaHS is a unique, non-profit, } \\
\text { community-based network of volunteers of all ages and } \\
\text { backgrounds working together to measure and map } \\
\text { precipitation (rain, snow, and hail). The network has 20,000 } \\
\text { active observers in all } 50 \text { states. CoCoRaHS provides reports } \\
\text { on daily precipitation, significant weather, multiple day } \\
\text { accumulation, drought impact, etc. [COCO 2011]. } \\
\text { Data Source: CoCoRaHS } \\
\text { Organization: CoCoRaHS network } \\
\text { Format Used: KML } \\
\text { Classification: Environment }\end{array}$ \\
\hline $\begin{array}{l}\text { Computer-Aided Management of } \\
\text { Emergency Operations (CAMEO) }\end{array}$ & $\begin{array}{l}\text { Description: CAMEO is a system of software applications } \\
\text { used widely to plan for and respond to chemical emergencies. } \\
\text { CAMEO can also be used to navigate between ALOHA (Areal } \\
\text { Locations of Hazardous Atmospheres), MARPLOT (Mapping } \\
\text { Applications for Response, Planning, and Local Operational } \\
\text { Tasks), and the downloadable version of CAMEO Chemicals. } \\
\text { All modules work interactively to share and display critical } \\
\text { information in a timely fashion. The CAMEO system is } \\
\text { available in Macintosh and Windows formats. CAMEO is a } \\
\text { database application that includes eight modules (such as } \\
\text { Facilities and Contacts) to assist with data management } \\
\text { requirements under the Emergency Planning and Community } \\
\text { Right-to-Know Act (EPCRA). The system includes a chemical } \\
\text { database of over 6,000 hazardous chemicals, 80,000 synonyms, } \\
\text { and product trade names. It provides a search engine to find } \\
\text { chemicals instantly for support making plan for and respond to } \\
\text { chemical emergencies [EPA 2011a]. } \\
\text { Data Source: CAMEOfm Version 2.0 } \\
\text { Organization: Environment Protection Agency (EPA); } \\
\text { National Oceanic; Atmospheric Administration (NOAA) } \\
\text { Format Used: ASCII } \\
\text { Classification: Environment; Controlling Documents }\end{array}$ \\
\hline $\begin{array}{l}\text { Consolidated Database System } \\
\text { (CDBS) }\end{array}$ & $\begin{array}{l}\text { Description: The FCC Media Bureau is responsible for } \\
\text { licensing broadcast services in the Unites States. The licensing } \\
\text { information for broadcast radio (AM and FM) and television } \\
\text { (TV, LPTV, and DTV) is contained in the Consolidated } \\
\text { Database System (CDBS).The CDBS is used to track the filing } \\
\text { and completion of broadcast construction permit, license, } \\
\text { renewal, ownership, assignment of license (sale of station), } \\
\text { transfer of control (change of ownership structure), and EEO } \\
\text { (Equal Employment Opportunity) applications. The CDBS } \\
\text { Public Access links access web pages that provide the ability to } \\
\text { search and retrieve information from FCC Media Bureau } \\
\text { databases for broadcast stations, and for certain EEO } \\
\text { information for broadcast stations and Cable and MVPD } \\
\text { (Multi-channel Video Programming Distributor) employment }\end{array}$ \\
\hline
\end{tabular}




\begin{tabular}{|c|c|}
\hline & $\begin{array}{l}\text { units [FCC 2011]. } \\
\text { Data Source: CDBS Public Searches } \\
\text { Organization: Federal Communications Commission (FCC) } \\
\text { Format Used: PDF; HTML } \\
\text { Classification: Resources }\end{array}$ \\
\hline DC Atlas & $\begin{array}{l}\text { Description: The DC Atlas is a web-based tool that contains } \\
\text { over } 150 \text { map layers arranged in various overlay categories. } \\
\text { Each overlay grouping is interactive, allowing users to zoom in } \\
\text { and out, move to different places, and identify features for more } \\
\text { information. The DC Atlas provides detailed maps with GIS } \\
\text { functionality. The information can be retrieved from its All-in- } \\
\text { One Service. Additionally, maps and information can be } \\
\text { printed. The service provides access to a wide range of } \\
\text { planimetric, cultural, environment datasets enabling users to } \\
\text { create their own maps easily and quickly [DC 2011]. } \\
\text { Data Source: DC Atlas All-In-One } \\
\text { Organization: Government of the District of Columbia } \\
\text { Format Used: TXT; CSV; Shapefile; MXD (ArcGIS Map } \\
\text { Document) } \\
\text { Classification: Incidents; Environment; Resources; Spatial, } \\
\text { Demographic and Behavioral }\end{array}$ \\
\hline $\begin{array}{l}\text { Earth Observing System (EOS) Data } \\
\text { Services }\end{array}$ & $\begin{array}{l}\text { Description: The Earth Observing System (EOS) is a } \\
\text { coordinated series of polar-orbiting and low inclination } \\
\text { satellites for long-term global observations of the land surface, } \\
\text { biosphere, solid Earth, atmosphere, and oceans. EOS is a major } \\
\text { component of the Earth Science Division of NASA's Science } \\
\text { Mission Directorate. EOS enables an improved understanding } \\
\text { of the Earth as an integrated system. The EOS Data Gateway } \\
\text { (EDG) is the primary interface to all data available in NASA's } \\
\text { Earth Observation System Data Information System, and } \\
\text { related data centers. With EDG, a user can search for and } \\
\text { acquire a large variety of earth, ocean, and atmospheric science } \\
\text { data obtained from EOS instruments such as MODIS and } \\
\text { MISR, as well as other satellites such as Landsat [NASA 2011]. } \\
\text { Data Source: EOS Data Gateway (EDG) } \\
\text { Organization: National Aeronautics and Space Administration } \\
\text { (NASA) } \\
\text { Format Used: TXT } \\
\text { Classification: Environment }\end{array}$ \\
\hline $\begin{array}{l}\text { Emergency Preparedness Resource } \\
\text { Inventory (EPRI) }\end{array}$ & $\begin{array}{l}\text { Description: Emergency Preparedness Resource Inventory } \\
\text { (EPRI) is a Web-based tool allowing local or regional planners } \\
\text { to assemble an inventory of critical resources that would be } \\
\text { useful in responding to a bioterrorist attack. It can be } \\
\text { customized for any region, state, or locality. EPRI creates } \\
\text { automated reports for use in preparedness and planning as well } \\
\text { as incident response [AHRQ 2011b]. } \\
\text { Data Source: Emergency Preparedness Resource Inventory } \\
\text { (EPRI) }\end{array}$ \\
\hline
\end{tabular}




\begin{tabular}{|c|c|}
\hline & $\begin{array}{l}\text { Organization: Agency for Healthcare Research and Quality } \\
\text { (AHRQ) } \\
\text { Format Used: ASCII } \\
\text { Classification: Resources; Incidents }\end{array}$ \\
\hline Envirofacts & $\begin{array}{l}\text { Description: The Envirofact Multisystem Search allows the } \\
\text { users to search multiple environmental databases for facility } \\
\text { information, including toxic chemical releases, water discharge } \\
\text { permit compliance, hazardous waste handling processes, } \\
\text { Superfund status, and air emission estimates. Search the } \\
\text { Envirofacts data using any combination of the following } \\
\text { criteria: facility name, geography, facility industrial } \\
\text { classification, or pollutant. Envirofacts offers several choices } \\
\text { for downloading data: EZ Searcher, Custom Searches, and } \\
\text { Geospatial Download. Through different search options, users } \\
\text { can select data from EPA’s Facility Registry System (FRS), } \\
\text { Locational Reference Database, Toxics Release Inventory } \\
\text { (TRI), Permit Compliance System (PCS), and RadNet } \\
\text { (formerly the Environmental Radiation Ambient Monitoring } \\
\text { System (ERAMS) and build reports or files [EPA 2011b]. } \\
\text { Data Source: Envirofacts Multisystem Search } \\
\text { Organization: Environmental Protection Agency (EPA) } \\
\text { Format Used: Table; CSV; XML; KML; Shapefile; } \\
\text { Environmental Systems Research Institute (ESRI) Feature } \\
\text { Class } \\
\text { Classification: Environmental; Resources }\end{array}$ \\
\hline Geodatabase & $\begin{array}{l}\text { Description: The Geodatabase is a storage and management } \\
\text { framework for geographic information systems (GIS) Data. It } \\
\text { combines "geo" (spatial data) with "database” (data repository) } \\
\text { to create a central data repository for spatial data storage and } \\
\text { management. It is designed to store, query, and manipulate } \\
\text { geographic information and spatial data. The Geodatabase } \\
\text { Toolset (GDBT) 9.3/9.3.1 is available for monitoring, } \\
\text { investigating, and reporting the performance of multiuser } \\
\text { geodatabase [ESRI 2011b]. } \\
\text { Data Source: GEODATABASE Toolset (GDBT) } \\
\text { Organization: U.S. Geological Survey } \\
\text { Format Used: SQL } \\
\text { Classification: Environment; Spatial }\end{array}$ \\
\hline $\begin{array}{l}\text { Geospatial Multi-Agency } \\
\text { Coordination Group (GeoMAC) }\end{array}$ & $\begin{array}{l}\text { Description: The Geospatial Multi-Agency Coordination } \\
\text { Group (GeoMAC) is an internet-based mapping application } \\
\text { originally designed for fire managers to access online maps of } \\
\text { current fire locations and perimeters in the conterminous } 48 \\
\text { States and Alaska. Using a standard web browser, fire } \\
\text { personnel can view this information to pinpoint the affected } \\
\text { areas. With the growing concern of western wildland fires in } \\
\text { the summer of 2000, this application has also become available } \\
\text { to the public. In order to give fire managers near real-time } \\
\text { information, fire perimeter data is updated daily based upon }\end{array}$ \\
\hline
\end{tabular}




\begin{tabular}{|c|c|}
\hline & $\begin{array}{l}\text { input from incident intelligence sources, GPS data, infrared } \\
\text { (IR) imagery from fixed wing and satellite platforms. The } \\
\text { GeoMAC web site allows users in remote locations to } \\
\text { manipulate map information displays, zoom in and out to } \\
\text { display fire information at various scales and detail, and print } \\
\text { hard copy maps for use in fire information and media briefings, } \\
\text { dispatch offices and coordination centers. The fire maps also } \\
\text { have relational databases in which the user can display } \\
\text { information on individual fires such as name of the fire, current } \\
\text { acreage and other fire status information [GEOMAC 2011]. } \\
\text { Data Source: GeoMAC Group } \\
\text { Organization: U.S. Department of the Interior; U.S. } \\
\text { Department of Agriculture; National Interagency Fire Center; } \\
\text { U.S. Geological Survey } \\
\text { Format Used: Feeds; ASCII; XML } \\
\text { Classification: Spatial; Environment }\end{array}$ \\
\hline Global Terrorism Database (GTD) & $\begin{array}{l}\text { Description: The Global Terrorism Database (GTD) is an } \\
\text { open-source database including information on terrorist events } \\
\text { around the world from } 1970 \text { through } 2008 \text { (with additional } \\
\text { annual updates planned for the future). Unlike many other } \\
\text { event databases, the GTD includes systematic data on domestic } \\
\text { as well as transnational and international terrorist incidents that } \\
\text { have occurred during this time period and now includes more } \\
\text { than 87,000 cases. For each GTD incident, information is } \\
\text { available on the date and location of the incident, the weapons } \\
\text { used and nature of the target, the number of casualties, and- } \\
\text { when identifiable-the group or individual responsible [UMD } \\
\text { 2011]. } \\
\text { Data Source: GTD online interface; "GTD Contact Form" } \\
\text { request } \\
\text { Organization: U.S. Department of Homeland Security; } \\
\text { National Consortium for the Study of Terrorism and Responses } \\
\text { to Terrorism } \\
\text { Format Used: CSV } \\
\text { Classification: Incidents; Demographic and Behavioral }\end{array}$ \\
\hline Google Earth & $\begin{array}{l}\text { Description: Offers maps and satellite images for complex or } \\
\text { pinpointed regional searches. } \\
\text { Data Source: Google Earth 5, Google Earth Pro } \\
\text { Organization: Google } \\
\text { Format Used: KLM; KMZ; COLLADA } \\
\text { Classification: Spatial }\end{array}$ \\
\hline Government Datasets & $\begin{array}{l}\text { Description: The purpose of Data.gov is to increase public } \\
\text { access to high value, machine readable datasets generated by } \\
\text { the Executive Branch of the Federal Government. Data.gov } \\
\text { provides descriptions of the Federal datasets (metadata), } \\
\text { information about how to access the datasets and tools that } \\
\text { leverage government datasets. Data.gov includes searchable } \\
\text { catalogs that provide access to "raw" datasets and various }\end{array}$ \\
\hline
\end{tabular}




\begin{tabular}{|c|c|}
\hline & 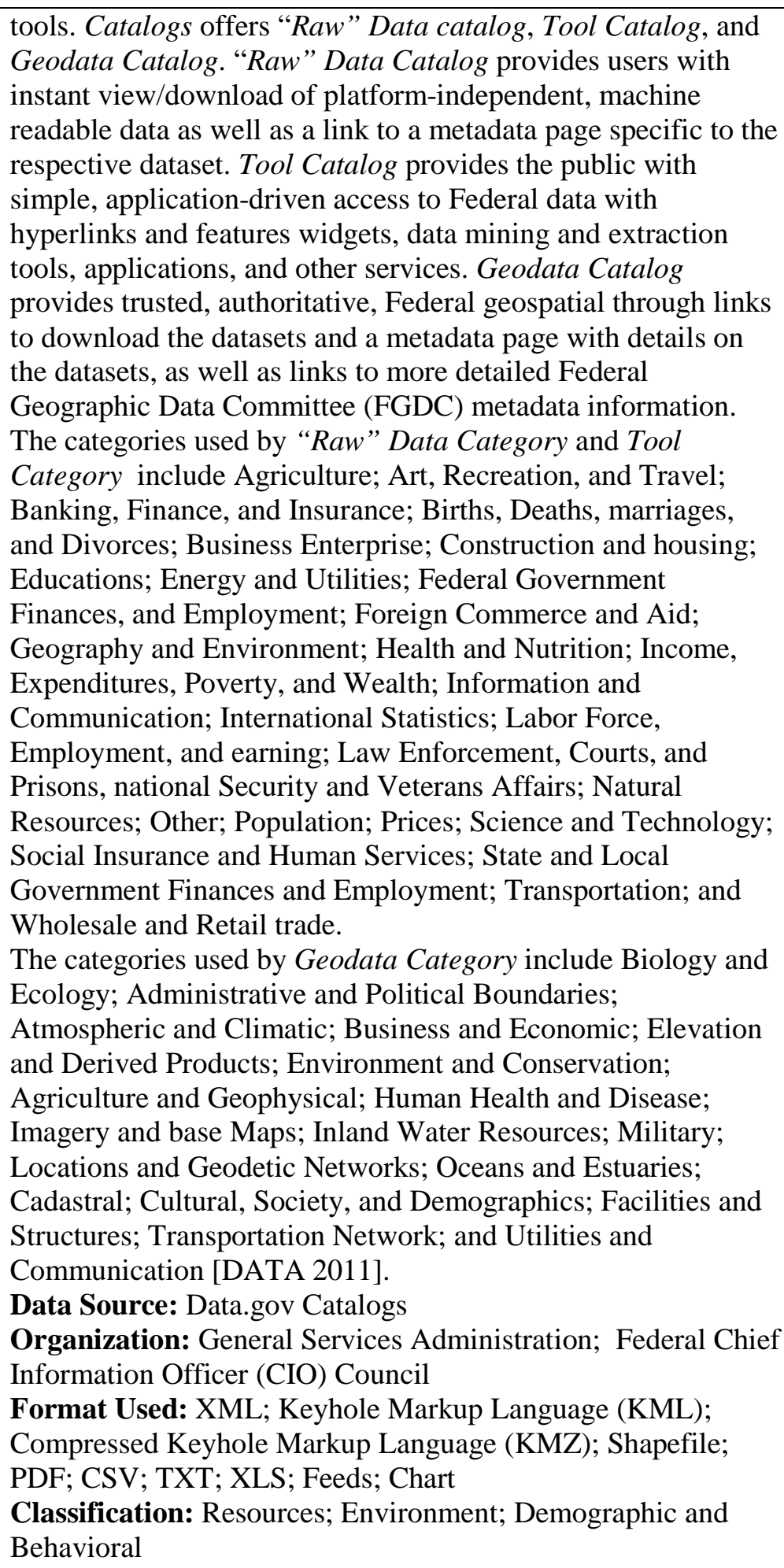 \\
\hline $\begin{array}{l}\text { Interactive GIS Web Mapping } \\
\text { Applications }\end{array}$ & $\begin{array}{l}\text { Description: The web applications, GIS-NET, SUB-NET, } \\
\text { OVOV-NET, and Z-NET allow for interactively viewing and } \\
\text { investigating zoning, land use policy, subdivision activity, } \\
\text { aerial imagery, and many other features pertaining to land use } \\
\text { within the unincorporated communities of Los Angeles County. }\end{array}$ \\
\hline
\end{tabular}




\begin{tabular}{|c|c|}
\hline & $\begin{array}{l}\text { GIS-NET provides geographic information regarding land use } \\
\text { planning and zoning for the unincorporated areas of Los } \\
\text { Angeles County. SUB-NET provides geographic information } \\
\text { regarding subdivision activity in the unincorporated areas of } \\
\text { Los Angeles County. OVOV-NET provides geographic } \\
\text { information regarding land use planning and zoning for the } \\
\text { incorporated areas of Santa Clarita Valley in the Los Angeles } \\
\text { County. Z-NET provides basic zoning and land use information } \\
\text { about properties in incorporate areas of Los Angeles County } \\
\text { [LACOUNTY 2011]. } \\
\text { Data Source: GIS-NET; SUB-NET; OVOV-NET; Z-NET } \\
\text { Organization: Los Angeles County Department of Regional } \\
\text { Planning } \\
\text { Format Used: GIF; PDF } \\
\text { Classification: Environment; Spatial }\end{array}$ \\
\hline $\begin{array}{l}\text { Montgomery County Government } \\
\text { Map Viewer }\end{array}$ & $\begin{array}{l}\text { Description: Montgomery County Government Map Viewer } \\
\text { contains over } 17 \text { thematic areas of data including aerial photos, } \\
\text { boundaries, census, economic development, education, } \\
\text { environmental protection, grids, health and human services, } \\
\text { housing, place of interest, public safety, public works and } \\
\text { transportation, recreation, regional services centers, streets and } \\
\text { zip codes, and other high accuracy base map datasets [MCMD } \\
\text { 2011]. } \\
\text { Data Source: Montgomery County Government Map Viewer } \\
\text { Organization: Montgomery County, Maryland Government } \\
\text { Format Used: GIF } \\
\text { Classification: Environment; Resources; Demographic and } \\
\text { Behavioral; Spatial }\end{array}$ \\
\hline $\begin{array}{l}\text { National Climatic Data Center } \\
\text { (NCDC) Geodata }\end{array}$ & $\begin{array}{l}\text { Description: NCDC, the world's largest active archive of } \\
\text { weather data, produces numerous climate publications and } \\
\text { responses to data requests from all over the world. NCDC } \\
\text { supports a three tier national climate services support program } \\
\text { - the partners include: NCDC, Regional Climate Centers, and } \\
\text { State Climatologists. The online Climate data Directory } \\
\text { includes Surface Data, Upper Air Data, Marine Data, Satellite } \\
\text { Data, Important Notes, Climatology \& Extremes, and Related } \\
\text { Links. NCDC provides data access tools to retrieve climate and } \\
\text { weather, satellite, and radar data [NCDC 2011a]. NCDC’s GIS } \\
\text { Portal allows users to view, access, and utilize in situ station } \\
\text { data through NCDC’s Geographic Information System (GIS) } \\
\text { portal. Interactive maps, associated metadata, and advanced } \\
\text { Open Geospatial Consortium (OGC) services, such as Web } \\
\text { Map Services (WMS) and Web Feature Services (WFS) are } \\
\text { available [NCDC 2011b]. } \\
\text { Data Source: National Climatic Data Center (NCDC) Geodata } \\
\text { Portal } \\
\text { Organization: NOAA } \\
\text { Format Used: WMS; WFS;KML;KMZ } \\
\text { Classification: Environment; Spatial }\end{array}$ \\
\hline
\end{tabular}




\begin{tabular}{|c|c|}
\hline $\begin{array}{l}\text { National Digital Forecast Database } \\
\text { (NDFD) }\end{array}$ & $\begin{array}{l}\text { Description: As the foundation of the NWS Digital Services } \\
\text { Program, the National Digital Forecast Database (NDFD) } \\
\text { consists of gridded forecasts of sensible weather elements (e.g., } \\
\text { cloud cover, maximum temperature). NDFD contains a } \\
\text { seamless mosaic of digital forecasts from NWS field offices } \\
\text { working in collaboration with the National Centers for } \\
\text { Environmental Prediction (NCEP) [NWS 2011a]. } \\
\text { Data Source: NDFD Access Data (via File Transfer Protocol } \\
\text { (FTP); HTTP; XML Web Service; Web Feature Service; Web } \\
\text { Browser) } \\
\text { Organization: National Weather Service (NWS) } \\
\text { Format Used: Grids in Gridded Binary (GRIB2); XML; } \\
\text { Shapefile } \\
\text { Classification: Environment }\end{array}$ \\
\hline $\begin{array}{l}\text { National Emergency Medical Services } \\
\text { (EMS) Information System (NEMSIS) }\end{array}$ & $\begin{array}{l}\text { Description: The National Emergency Medical Services } \\
\text { (EMS) Information System (NEMSIS) is the national } \\
\text { repository that will be used to potentially store EMS data from } \\
\text { every state in the nation. The NEMSIS project was developed } \\
\text { to help states collect more standardized elements and } \\
\text { eventually submit the data to a national EMS database. The } \\
\text { NEMSIS Technical Assistance Center (TAC) is the resource } \\
\text { center for the NEMSIS project. The 2009 NEMSIS Public- } \\
\text { Release Research Dataset is now available. This dataset } \\
\text { includes 6,216,520 EMS events submitted by } 26 \text { states during } \\
\text { the } 2009 \text { calendar year. The 2008 NEMSIS Public-Release } \\
\text { Research Dataset will continue to be available through the } \\
\text { NEMSIS TAC [NEMSIS 2010]. } \\
\text { Data Source: NEMSIS Technical Assistance Center } \\
\text { Organization: National Highway Traffic Safety } \\
\text { Administration (NHTSA); Health Resources and Services } \\
\text { Administration (HRSA); CDC } \\
\text { Format Used: XML } \\
\text { Classification: Demographic and Behavioral }\end{array}$ \\
\hline $\begin{array}{l}\text { National Fire Department Census } \\
\text { Database }\end{array}$ & $\begin{array}{l}\text { Description: The National Fire Department Census Database } \\
\text { provides an online address listing of U.S. fire departments } \\
\text { registered with U. S. Fire Administration (USFA) as well as } \\
\text { some basic information about each fire department. The } \\
\text { purpose of the census, which is ongoing, is to create a national } \\
\text { database for use by USFA to conduct special studies that will } \\
\text { guide program decision-making and to improve direct } \\
\text { communication with individual fire departments. Data in the } \\
\text { database may include These files contain the following } \\
\text { information: department name, headquarters address, } \\
\text { department mailing address, headquarters telephone number, } \\
\text { headquarters fax number, county, department type, } \\
\text { organization type, Web site address, number of stations, } \\
\text { number of active firefighters, the number of non-firefighting } \\
\text { personnel, and a flag indicating the department's status as }\end{array}$ \\
\hline
\end{tabular}




\begin{tabular}{|c|c|}
\hline & $\begin{array}{l}\text { primary emergency management department [USFA 2011]. } \\
\text { Data Source: National Fire Department Census Database } \\
\text { Organization: U.S. Fire Administration (USFA) } \\
\text { Format Used: CSV } \\
\text { Classification: Incidents, Controlling Documents }\end{array}$ \\
\hline $\begin{array}{l}\text { National Geochemical Survey } \\
\text { Database }\end{array}$ & $\begin{array}{l}\text { Description: The online spatial data is provided by the } \\
\text { National Geochemical Survey Database. The database contains } \\
\text { information from the National-scale geochemical analysis of } \\
\text { stream sediments and soils in the U.S., from existing data, } \\
\text { reanalysis of existing samples, and new sampling. Goal for } \\
\text { sample density is one per } 289 \text { square km. There are } 3 \text { ways to } \\
\text { get information: 1) View: show in a web browser window, } \\
\text { show in Google Earth or down load KML, and show in GIS } \\
\text { using OGC WMS; 2) Download: download data for selected } \\
\text { geographic areas; 3) Documentation: complete National } \\
\text { Geochemical Survey report available on the web [USGS } \\
\text { 2011b]. } \\
\text { Data Source: National Geochemical Survey Database } \\
\text { Organization: U.S. Geological Survey (USGS) } \\
\text { Format Used: Shapefile; dBase; HTML; TXT; CSV; KML; } \\
\text { KMZ } \\
\text { Classification: Environment; Spatial }\end{array}$ \\
\hline $\begin{array}{l}\text { National Geophysical Data Center } \\
\text { (NGDC) }\end{array}$ & $\begin{array}{l}\text { Description: The National Geophysical Data Center (NGDC) } \\
\text { Online Access Systems include Interactive Map Services, } \\
\text { Space Physics Interactive Data Resources (SPIDR), } \\
\text { Geophysical Data System (GEODAS), Seafloor Composition, } \\
\text { and FTP Area. Interactive Maps provides visually display for } \\
\text { many NGDC data layers. SPIDR is designed to allow a solar } \\
\text { terrestrial physics customer to intelligently access and manage } \\
\text { historical space and physics data for integration with } \\
\text { environment models and space weather forecasts. SPIDR is a } \\
\text { distributed network of synchronous databases. GEODAS is an } \\
\text { interactive database management system for used in the } \\
\text { assimilation, storage, and retrieval geophysical data. The data } \\
\text { included in the GEODAS are trackline marine geophysics, } \\
\text { hydrographic surveys, coastal relief, multi-beam bathymetry, } \\
\text { and aeromagnetic surveys. Download data directly, create } \\
\text { custom CDs. Seafloor Composition is used to search for and } \\
\text { download selected descriptions and analyses of marine } \\
\text { sediment and rock samples. FTP Area is for browse data types } \\
\text { available from NGDC [NGDC 2011]. } \\
\text { Data Source: NGDC Online Access Systems } \\
\text { Organization: National Oceanic and Atmospheric } \\
\text { Administration (NOAA)/National Geophysical Data Center } \\
\text { (NGDC) } \\
\text { Format Used: GIF; PNG; XML } \\
\text { Classification: Environment; Spatial }\end{array}$ \\
\hline
\end{tabular}




\begin{tabular}{|c|c|}
\hline $\begin{array}{l}\text { National Integrated Land System } \\
\text { (NILS) }\end{array}$ & $\begin{array}{l}\text { Description: GeoCommunicator is the publication site for the } \\
\text { Bureau of Land management’s (BLM's) National Integrated } \\
\text { Land System (NILS). NILS' Land Survey Information System } \\
\text { is the official federal government website for the distribution of } \\
\text { the Public Land Survey System - PLSS of the United States } \\
\text { and other survey-based data for the federal government. } \\
\text { GeoCommunicator provides searching, processing, and } \\
\text { dynamic mapping of many BLM activities, such as land use } \\
\text { permits; Mineral materials, community pits; oil, gas, and } \\
\text { geothermal leasing; mining claims; etc. It provides a } \\
\text { centralized site for downloading NILS data and exporting } \\
\text { survey points/lines and control points [BLM 2011]. } \\
\text { Data Source: GeoCommunicator } \\
\text { Organization: Bureau of Land Management (BLM) } \\
\text { Format Used: Shapefile } \\
\text { Classification: Environment; Resources }\end{array}$ \\
\hline $\begin{array}{l}\text { National Renewable Energy } \\
\text { Laboratory (NREL) Geographic } \\
\text { Information System (GIS) Data }\end{array}$ & $\begin{array}{l}\text { Description: The National Renewable Energy Laboratory } \\
\text { (NREL) Dynamic Maps, GIS Data and Analysis Tools Web } \\
\text { Site provides dynamically-generated maps of renewable energy } \\
\text { resources that determine which energy technologies are viable } \\
\text { solutions in national and international regions. Click on the } \\
\text { download data link in the page to activate the File Archive } \\
\text { Download Utility. Data are available for the U.S. and } \\
\text { internationally, and for energy resources including biomass, } \\
\text { hydrogen, solar, and wind. The NREL’s Geographic } \\
\text { Information System (GIS) team analyzes wind, solar, biomass, } \\
\text { geothermal, and other energy resources and inputs the data into } \\
\text { the GIS. NRFL has made some of their biomass, solar and wind } \\
\text { datasets - in either high resolution or low resolution - } \\
\text { available for download through this Web site. High-resolution } \\
\text { datasets are available for specific states. Low-resolution } \\
\text { datasets are available for Alaska, Hawaii, and the lower } 48 \\
\text { states [NREL 2011]. } \\
\text { Data Source: NREL’s Geographic Information System Data } \\
\text { Organization: The National Renewable Energy Laboratory } \\
\text { (NREL) } \\
\text { Format Used: SHP } \\
\text { Classification: Resources; Spatial }\end{array}$ \\
\hline $\begin{array}{l}\text { National Weather Service File/Web } \\
\text { Services }\end{array}$ & $\begin{array}{l}\text { Description: The National Weather Service } \\
\text { Telecommunication Gateway web site contains information on } \\
\text { meteorological data exchange, communication standards, } \\
\text { switching practices, and meteorological data codes. The } \\
\text { File/Web Services allows user to access data and products filed } \\
\text { on the Gateway central server resources using FTP and HTTP } \\
\text { applications. The File/Web Services provide current data and } \\
\text { product files of computer models, text products, text parsed } \\
\text { data, observed data, radar products, and satellite products } \\
\text { [NWS 2011b]. } \\
\text { Data Source: File/Web Services }\end{array}$ \\
\hline
\end{tabular}




\begin{tabular}{|c|c|}
\hline & $\begin{array}{l}\text { Organization: National Weather Service } \\
\text { Format Used: GRIB; FTP; HTTP; RPG/SPG; NESDIS; TXT } \\
\text { Classification: Incidents; Environment }\end{array}$ \\
\hline $\begin{array}{l}\text { Public Utilities Commission } \\
\text { Interactive Maps }\end{array}$ & $\begin{array}{l}\text { Description: The Public Utilities Commission of Ohio’s } \\
\text { Interactive Maps Page was created to provide on-line access to } \\
\text { the PUCO’s Geographic Information System (GIS) maps and } \\
\text { database. The various maps enable the user to search, identify, } \\
\text { and print information on data layers including service area } \\
\text { boundaries, exchanges, roads, school districts, county } \\
\text { boundaries, cities, political districts, railroad crossings, etc. } \\
\text { The maps types include telephone/electric/rail map; telephone } \\
\text { service map, electric map, railroad cross accident maps, } \\
\text { railroad map, water and waste water utilities map, telephone } \\
\text { extended area service map, census boundary and zip code map, } \\
\text { etc. [PUCO 2011]. } \\
\text { Data Source: PUCO Interactive Maps } \\
\text { Organization: The Public Utilities Commission of Ohio } \\
\text { (PUCO) } \\
\text { Format Used: PDF; Google Map } \\
\text { Classification: Spatial; Environment; Incidents; Resources }\end{array}$ \\
\hline QuickFacts & $\begin{array}{l}\text { Description: QuickFacts is an easy access to facts about } \\
\text { people, business, and geography. It includes data for all states } \\
\text { and counties, and for cities and towns with more than 25,000 } \\
\text { people. QuickFacts tables are summary profiles showing } \\
\text { frequently requested data items from various Census Bureau } \\
\text { programs. Profiles are available for the nation, states, counties, } \\
\text { and large cities [CENSUS 2011e]. } \\
\text { Data Source: QuickFacts } \\
\text { Organization: U.S. Census Bureau } \\
\text { Format Used: ASCII } \\
\text { Classification: Spatial; Resources; Demographic and } \\
\text { Behavior; Environment }\end{array}$ \\
\hline $\begin{array}{l}\text { San Francisco Enterprise Geographic } \\
\text { Information Systems (GIS) Program }\end{array}$ & $\begin{array}{l}\text { Description: The San Francisco Enterprise GIS Program } \\
\text { provides mapping expertise, data, and applications for the City } \\
\text { and County of San Francisco. The Program provides four } \\
\text { mapping services: SFViewer, SFParcel, SFProspector, and } \\
\text { CrimeMaps. With SFViewer and SFParcel, users can find a } \\
\text { location or an assessor parcel, view parcel information, view } \\
\text { aerial photos, and print maps. SFProspector allows searching } \\
\text { for properties and creating demographic or business report for } \\
\text { an area of San Francisco. CrimeMaps provides the public with } \\
\text { information about recent crime activity in their neighborhood } \\
\text { [SFGOV 2011]. } \\
\text { Data Source: SFViewer; SFParcel; SFProspector; CrimeMaps } \\
\text { Organization: City \& County of San Francisco } \\
\text { Format Used: GIF; TXT; ASCII } \\
\text { Classification: Resources; Spatial; Environment; Demographic } \\
\text { and Behavioral }\end{array}$ \\
\hline
\end{tabular}




\begin{tabular}{|c|c|}
\hline SEDRIS Environmental Data Sets & $\begin{array}{l}\text { Description: SEDRIS includes the representation of } \\
\text { environmental data and the interchange of environmental data } \\
\text { sets. The SEDRIS environmental data sets are available free of } \\
\text { charge from SEDRIS. The types of SEDRIS data sets include } \\
\text { models (e.g., chair, communication console, space station } \\
\text { gamma, and test), Terrain (e.g., Atlantis, Auto-generated } \\
\text { Terrain, Bellevue Washington, and Lake Tahoe), and other } \\
\text { domains (e.g., atmosphere, Master Environmental Library), and } \\
\text { data achieves (e.g., 4.0-compliant SEDRIS Transmittal } \\
\text { Formats) [SEDRIS 2011b]. } \\
\text { Data Source: SEDRIS Environmental Databases } \\
\text { Organization: Defense Advanced Research Projects Agency } \\
\text { (DARPA) } \\
\text { Format Used: SEDRIS Transmittal Format (SFT) } \\
\text { Classification: Environment }\end{array}$ \\
\hline $\begin{array}{l}\text { The Federated Data System } \\
\text { (DataFed) }\end{array}$ & $\begin{array}{l}\text { Description: DataFed is web services-based software that non- } \\
\text { intrusively mediates between autonomous, distributed data } \\
\text { providers and users. The main goals of DataFed include to aid } \\
\text { air quality management and science by effective use of relevant } \\
\text { data, to facilitate the access and flow of atmospheric data from } \\
\text { provider to users, and to support the development of user- } \\
\text { driven data processing value chains. The main web application } \\
\text { of DataFed is the generic Viewer of spatio-temporal datasets. } \\
\text { The Viewer can be used for all the federated datasets in } \\
\text { DataFed [DATAFED 2011]. } \\
\text { Data Source: DataFed Viewer } \\
\text { Organization: National Science Foundation (NSF); National } \\
\text { Aeronautics and Space Administration (NASA) } \\
\text { Format Used: CSV; KML } \\
\text { Classification: Environment }\end{array}$ \\
\hline The National Map & $\begin{array}{l}\text { Description: The National Map is a collaborative effort among } \\
\text { the USGS and other Federal, State, and local partners to } \\
\text { improve and deliver topographic information for the Nation. It } \\
\text { has many uses ranging from recreation to scientific analysis to } \\
\text { emergency response. The National Map includes several } \\
\text { primary data viewers: the first viewer, The National Map } \\
\text { Viewer, has the primary role of viewing distributed data sets } \\
\text { from many contributing Federal State and Local Partners } \\
\text { through dynamic web map services. The second viewer, The } \\
\text { National Map Seamless Server, is the primary site for } \\
\text { downloading USGS imagery, elevation and land cover data. } \\
\text { Use the 'Best Practices' viewer to download the most up-to-date } \\
\text { National Map road, boundaries, structures and other 'vector' } \\
\text { data. Use the National Hydrography Data (NHD) viewer to } \\
\text { download our full featured National Hydrography data [NMAP } \\
\text { 2011]. } \\
\text { Data Source: The National Map } \\
\text { Organization: U.S. Geological Survey }\end{array}$ \\
\hline
\end{tabular}




\begin{tabular}{|c|c|}
\hline & $\begin{array}{l}\text { Format Used: PDF; GeoPDF; GeoTIFF; SHP; JPEG } \\
\text { Classification: Spatial }\end{array}$ \\
\hline $\begin{array}{l}\text { The North American Environmental } \\
\text { Atlas }\end{array}$ & $\begin{array}{l}\text { Description: The North American Environmental Atlas is a } \\
\text { digital repository of maps and information that are available as } \\
\text { downloadable map and data files without cost. It is an } \\
\text { interactive mapping tool to research, analyze and manage } \\
\text { environmental issues in Canada, United States and Mexico. It is } \\
\text { designed to help understand continental-scale environmental } \\
\text { issues. The Atlas offers basic cartographic and environmental } \\
\text { data for the continent. It is intended for use by both } \\
\text { environmental scientists and the citizens of the United States, } \\
\text { Canada, and Mexico. Its maps and services are designed to } \\
\text { help the public visualize environmental topics at a continental } \\
\text { scale [CEC 2011]. } \\
\text { Data Source: North American Environmental Atlas } \\
\text { Organization: Commission for Environmental Cooperation } \\
\text { (CEC) } \\
\text { Format Used: Shapefile; PDF; ZIP } \\
\text { Classification: Environment }\end{array}$ \\
\hline $\begin{array}{l}\text { Topologically Integrated Geographic } \\
\text { Encoding and Referencing (TIGER) } \\
\text { Database }\end{array}$ & $\begin{array}{l}\text { Description: The Web browser is used to view and download } \\
\text { Topologically Integrated Geographic Encoding and } \\
\text { Referencing (TIGER) data. The design of the TIGER database } \\
\text { adapts the theories of topology, graph theory, and associated } \\
\text { fields of mathematics to provide a disciplined, mathematical } \\
\text { description for the geographic structure of the United States } \\
\text { and its territories [CENSUS 2011f]. } \\
\text { Data Source: Tiger Map Server Browser } \\
\text { Organization: U.S. Census Bureau } \\
\text { Format Used: SHP; Tiger/Line; ASCII; XML } \\
\text { Classification: Spatial }\end{array}$ \\
\hline $\begin{array}{l}\text { U.S. Board on Geographic Names } \\
\text { Database }\end{array}$ & $\begin{array}{l}\text { Description: The U.S. Board on Geographic Names serves the } \\
\text { Federal Government and the public as a central authority to } \\
\text { which name problems, name inquiries, name changes, and new } \\
\text { name proposals can be directed. The U.S. Board on Geographic } \\
\text { Names Database holds the Federally recognized name of each } \\
\text { feature and defines the feature location by state, county, USGS } \\
\text { topographic map, and geographic coordinates. Other attributes } \\
\text { include names or spellings other than the official name, feature } \\
\text { designations, feature classification, historical and descriptive } \\
\text { information, and for some categories the geometric boundaries. } \\
\text { Use "Search Domestic Names", "Download Domestic Names", } \\
\text { "Search Foreign Names", and "Search Antarctic Names” to } \\
\text { query or download information [USGS 2011c]. } \\
\text { Data Source: Online Systems: Search Domestic Names, } \\
\text { Download Domestic Names } \\
\text { Organization: U.S. Geological Survey } \\
\text { Format Used: XML; HTML; ASCII } \\
\text { Classification: Controlling Document }\end{array}$ \\
\hline
\end{tabular}




\begin{tabular}{|c|c|}
\hline $\begin{array}{l}\text { United States-Mexico Demographic } \\
\text { Data }\end{array}$ & $\begin{array}{l}\text { Description: United States-Mexico Demographic Data Viewer } \\
\text { is an interactive application that provides rapid, interactive data } \\
\text { mapping, viewing, and analysis of more than } 200 \\
\text { socioeconomic variables that are congruent between the United } \\
\text { States and Mexico. It is a useful tool for browsing and } \\
\text { visualizing patterns at geographic levels ranging from regions } \\
\text { to counties/ municipalities, the U.S.-Mexico DDViewer may be } \\
\text { used to map population, vital statistic, land area, and household } \\
\text { data [CU 2011]. } \\
\text { Data Source: DDViewer } 3.1 \\
\text { Organization: Columbia University, International Earth } \\
\text { Science Information Network (CIESIN) } \\
\text { Format Used: } \\
\text { Classification: Spatial; Demographic and Behavioral; } \\
\text { Resources }\end{array}$ \\
\hline $\begin{array}{l}\text { Westchester County Geographic } \\
\text { Information Systems }\end{array}$ & $\begin{array}{l}\text { Description: The Mapping Westchester County of New York } \\
\text { map service provides access to a large amount of facility, } \\
\text { environmental, demographic, transportation, and large scale } \\
\text { planimetric datasets. Links to other areas of the county’s GIS } \\
\text { website also enables users to download coverage and metadata } \\
\text { [WCNY 2011]. } \\
\text { Data Source: Westchester County Geographic Information } \\
\text { Systems } \\
\text { Organization: Westchester County, New York Government } \\
\text { Format Used: GIF } \\
\text { Classification: Incidents; Environment; Resources; } \\
\text { Demographic and Behavioral; Spatial }\end{array}$ \\
\hline
\end{tabular}

\section{Discussions and Recommendations}

This section is intended to capture practices and issues relevant to program sponsors, project managers, researchers, developers, and implementers of M\&S of CIKR for homeland security applications. The resources presented in section 6 and research, development and implementation experiences are used to identify the best practices to be followed for future efforts and to provide uncertainties, cautions and warnings for use of such applications. Further, the resources in section 6 are compared with the information in sections 4 and 5 to identify the unmet needs and requirements. These unmet needs and requirements are used to identify and prioritize the research, development, standards, and implementation issues that should be addressed going forward. This section hence provides a summary of discussion topics and recommendations that are divided into three major areas:

- Identification of best practices (Section 7.1)

- Uncertainties, cautions and warnings regarding expectations of these models and simulations (Section 7.2)

- Research, development, standards and implementation issues that may need to be addressed by the research community, program sponsors, and stakeholders to improve the quality and utility of incident management models and simulations (Section 7.3) 
The initial versions of the following subsections are intended to provide a starting point for discussions during the workshop.

\section{1. $\quad$ Best Practices}

Best practices are really only effective if a methodology is well defined for a given problem solving approach. For example, the LUMAS model shows how learning influences a documented methodology, and the link between L and M in the LUMAS model is where best practice is encountered by the user of a methodology. The risk management framework defined in the National Infrastructure Protection Plan (NIPP) [DHS 2009] provides the high level methodology relevant to use of modeling and simulation for CIKR. The best practices included here will primarily focus on those used for modeling and simulation tool development, deployment, and use in support of the NIPP risk management framework.

A variety of M\&S approaches, methodologies, and tools are currently available. Some are more suitable to solving certain classes of problems than others. This section will identify recommended approaches and best practices for solving different types of CIKR modeling problems.

- Provide tools that can be used at the local level for critical infrastructure analysis, evaluation, or training purposes

- Use various test and validation methods

- Provide tools that do not require sophisticated and expensive system support

- Provide distributed web-based tools that allow CIKR organizations to develop and run custom exercises.

\subsection{Limitations, Cautions and Warnings}

This sub-section is intended to highlight and document the limitations associated with M\&S applications to minimize improper use and highlight potential areas for further development. M\&S application requires significant effort and hence they should be utilized only when appropriate, i.e., they should be considered for complex problems that cannot be addressed using other analytical options. The level of detail and specificity achieved by using the most sophisticated models and simulations may not be practical or necessary for all assets, systems, or networks. In these circumstances, a simplified dependency and interdependency analysis based on expert judgment may provide sufficient insight to make informed risk management decisions in a timely manner (DHS 2009).

For applications that are identified as suitable for M\&S applications, it should be recognized that models provide results with varying levels of error and uncertainty. Analysts should ensure that decision-makers understand the uncertainties in M\&S results and other limitations such as the ones listed below.

- $\quad$ Training exercises may not create the stress conditions and state of mind in the response personnel that would occur during a real incident such as a massive failure or attack on a CIKR system.

- Data inconsistencies between simulated exercises and real incidents may affect the results and perceptions.

- Communication difficulties and incompatibilities between systems may not be accurately reflected in training exercises.

\subsection{Research, Development, Standards and Implementation Issues}

A number of research, development, standards, and implementation issues remain to be addressed. An initial straw man list follows: 
- Identification of appropriate models, simulations, tools, and databases to address CIKR analysis needs

- Identification of common models, simulations, tools, and databases that can be shared by SSAs with the user community

- Identification of technical gaps and needs for models, simulations, tools, and databases

- Development of system requirements specifications for CIKR models, simulations, tools, and databases

- Development of systems dynamics models for addressing strategic issues for different CIKR sectors and systems

- Development of mechanisms to enable access to and usage of CIKR M\&S applications by SSAs, CIKR partners, and operational personnel

- Development of simulation application architectures to enable module integration and standard data interfaces to import data from external databases

- Use of a system of systems engineering approach to the development of applications

- Use of UML/SysML in specification of CIKR systems and M\&S applications

- Development of M\&S applications as open systems

- Use of object-oriented models in CIKR M\&S

- Integration of CIKR models and simulations

- Establishment of security and protection mechanisms for sensitive data

- Ownership and usage of publicly vs. privately developed models, simulations, tools, and databases

- Return on investment to stakeholders and sponsors for research projects

\section{Conclusion}

This initial version of the document is the starting point of an effort to capture the current knowledge relevant to M\&S of CIKR for homeland security applications. It identifies the needs, translates them into requirements and provides summary information on resources available to meet the needs and requirements. The information on needs, requirements, and resources is used together with research, development, and implementation experiences to distill practices and issues for future efforts.

This version will be used to facilitate input from domain experts in a workshop setting. It is hoped that the next version updated with such input will provide value as a reference for program managers, project managers, researchers, developers, and implementers of M\&S of CIKR for homeland security applications. Use of the updated document as a common reference may help increase the awareness across the associated communities and help enhance collaborative efforts for homeland security applications of M\&S for CIKR.

\section{References}

[Abdalla 2007]

[ADL 2011]

Abdalla, R., Tao, V., Cheng, Q., Li, J., 2007, A network-centric modeling approach for infrastructure interdependency, Photogrammetric Engineering \& Remote Sensing, 73(6), 681-690.

Advanced Distributed Learning Sharable Content Object Reference Model (SCORM). Available via: http://www.adlnet.gov/Technologies/scorm/default.aspx [accessed Jan. 10, 2011].

Health Care Statistics \& Market Research: AHA Data. Available via: http://www.ahadata.com/ahadata_app/index.jsp [accessed Mar. 25, 2011]. 
[AHD 2011]

[AHRQ 2011a]

[AHRQ 2011b]

[ANL 2011a]

[ANL 2011b]

[ANL 2011c]

[ANL 2011d]

[ANS 2011]

[ANSI 2011a]

[ANSI 2011b]

[ANSI 2011c]

[Apostolakas 2005]

[APTATCIP 2011]

[ASTM 2011a]

[ASTM 2011b]
American Hospital Directory. Available via: http://www.ahd.com/ [accessed Mar. 25, 2011].

Community-Based Mass Prophylaxis - A Planning Guide for Public Health Preparedness. Agency for Health Research and Quality (AHRQ). Available via: http://www.ahrq.gov/research/cbmprophyl/cbmpro.htm [accessed Mar. 25, 2011]. Emergency Preparedness Resource Inventory (EPRI): A Tool for Local, Regional, and State Planners. Agency for Health Research and Quality (AHRQ). Available via: http://www.ahrq.gov/research/epri/ [accessed Mar. 25, 2011]. Electricity Market Complex Adaptive System (EMCAS). Decision and Information Sciences. Argonne National Laboratory. Available via: http://www.dis.anl.gov/projects/emcas.html [accessed Jan. 13, 2011]. CEEESA Natural Gas Systems Analysis Tools. Center for Energy, Environmental, and Economic Systems Analysis (CEEESA), Decision and Information Sciences. Argonne National Laboratory. Available via: http://www.dis.anl.gov/projects/NaturalGasAnalysisTools.html [accessed Jan. 13, 2011].

Restore: Modeling Interdependent Repair/Restoration Processes. Decision and Information Sciences. Argonne National Laboratory. Available via: http://www.dis.anl.gov/pubs/60362.pdf [accessed Jan. 13, 2011].

Threat Ensemble Vulnerability Assessment (TEVA). Decision and Information Sciences. Argonne National Laboratory. Available via: http://www.dis.anl.gov/projects/teva.html [accessed Jan. 13, 2011]. American Nuclear Society (ANS) Standards Store. Available via: http://www.new.ans.org/store/i_240246 [accessed Mar. 25, 2011]. American National Standards Institute (ANSI) Standards Store - Spatial Data Standard for Facilities, Infrastructure, and Environment (SDSFIE). Available via: http://webstore.ansi.org/RecordDetail.aspx?sku=ANSI+INCITS+353-2006 [accessed Jan. 15, 2011].

American National Standards Institute (ANSI) Standards Store - Homeland Security Mapping Standard: Point Symbology for Emergency Management. Available via:

http://webstore.ansi.org/RecordDetail.aspx?sku=ANSI+INCITS+415-2006 [accessed Mar. 25, 2011].

American National Standards Institute (ANSI) Standards Store - Unified Modeling Language (UML). Available via:

http://webstore.ansi.org/RecordDetail.aspx?sku=ISO\%2fIEC+19501\%3a2005\&s ource=google\&adgroup=iso9\&keyword=iso\%2Fiec\%2019501 [accessed Jan. 28, 2011].

Apostolakas, G., and Lemon, D., 2005. A Screening Methodology for the Identification and Ranking of Infrastructure Vulnerabilities Due to Terrorism. Risk Analysis, Vol. 25, No. 2, pp. 361-376.

American Public Transportation Association (APTA) Transit Communications Interface Profiles (TCIP) Standard Development Program. Available via: http://aptatcip.com/ [accessed Mar. 25, 2011].

Standard Practice for Metadata to Support Archived Data Management Systems. ASTM International, Inc. (ASTM). Available via: http://www.astm.org/Standards/E2468.htm [accessed Mar. 25, 2011]. Standard Specification for Telecommunications and Information Exchange Between Roadside and Vehicle Systems - 5 GHz Band Dedicated Short Range Communications (DSRC) Medium Access Control (MAC) and Physical Layer (PHY) Specifications. ASTM International, Inc. (ASTM). Available via: 
[ASTM 2011c]

[Bagheri 2007]

[Balci 1998]

[Barton 2004]

[BLM 2011]

[Boyd 2009]

[Brutzman 2006]

[Carreras 2009]

[CDC 2011a]

[CDC 2011b]

[CDC 2011c]

[CEC 2011]

[CENSUS 2011b]

[CENSUS 2011c]

[CENSUS 2011d]
http://www.astm.org/Standards/E2213.htm [accessed Mar. 25, 2011].

Standard Specification for Archiving ITS-Generated Traffic Monitoring Data. ASTM International, Inc. (ASTM). Available via: http://www.astm.org/Standards/E2665.htm [accessed Mar. 25, 2011]. Bagheri, E., H. Baghi, A.A. Ghorbani, and A. Yari, 2007. An Agent-based Service-Oriented Simulation Suite for Critical Infrastructure Behavior Analysis, International Journal of Business Process Integration and Management , 2(4), 312 - 326. Available via: http://glass.cs.unb.ca/ ebrahim/papers/ijbpim.pdf [accessed Jan. 12, 2011].

Verification, Validation, and Testing. In Handbook of Simulation: Principles, Methodology, Advances, Applications, and Practice. Edited by J. Banks. WileyInterscience.

Barton, D.C., E.D. Edison, D.A. Schoenwald, R.G. Cox, and R.K. Reinert. 2004.

Simulating Economic Effects of Disruptions in the Telecommunications

Infrastructure. Report no. SAND2004-0101. January 2004. Sandia National

Laboratories, Albuquerque, NM and Livermore, CA.

National Integrated Land System (NILS). Bureau of Land Management (BLM). Available via: http://www.blm.gov/nils/ [accessed Mar. 25, 2011].

Boyd, D., 2009. Virtual USA. Briefing delivered during the Commercial Mobile Alert Service (CMAS) Forum, July 30, 2009. Available via:

http://cmasforum.com/docs/Forum_Master_Slide_Deck_FINAL.ppt [accessed

Jan. 12, 2011].

Brutzman, D., C. Blais, and T. Norbraten, 2006. Modeling and 3D Visualization for Evaluation of Anti-Terrorism/Force Protection Alternatives Phase II Final Report. Naval Postgraduate School, Monterey, CA. 21 November 2006.

Available via:

http://edocs.nps.edu/npspubs/scholarly/TR/2006/NPS-MV-06-002.pdf [accessed Jan. 12, 2011].

Carreras, B.A., D.E. Newman, I. Dobson, and M. Zeidenberg. 2009. A simple model for the reliability of an infrastructure system controlled by agents. Proceedings ${ }^{\text {of }}$ the 42nd Hawaii International Conference on System Sciences. Classification of Diseases, Functioning, and Disability. Centers for Disease Control and Prevention (CDC). Available via: http://www.cdc.gov/nchs/icd/icd10cm.htm [accessed Mar. 25, 2011]. Public Health Emergency Response Guide for State, Local, and Tribal Public Health Directors. Centers for Disease Control and Prevention (CDC). Available via: http://www.bt.cdc.gov/planning/responseguide.asp [accessed Mar. 25, 2011]. Smallpox Response Plan and Guidelines. Centers for Disease Control and Prevention (CDC). Available via:

http://www.bt.cdc.gov/agent/smallpox/response-plan/ [accessed Mar. 25, 2011]. North American Environmental Atlas. Available via: http://www.cec.org/Page.asp?PageID=924\&SiteNodeID=495\&AA_SiteLanguage ID=1 [accessed Mar. 25, 2011].

American Community Survey. U.S. Census Bureau. Available via: http://www.census.gov/acs/www/ [accessed Mar. 25, 2011].

American FactFinder. U.S. Census Bureau. Available via:

http://factfinder.census.gov/home/saff/main.html?_lang=en [accessed Mar. 25, 2011].

American Housing Survey (AHS). U.S. Census Bureau. Available via: http://www.census.gov/hhes/www/housing/ahs/ahs.html [accessed Mar. 25, 2011]. 
[CENSUS 2011e]

[CENSUS 2011f]

[CHDS 2011]

[Checkland 2000]

[Cheng 2007]

[CHICAGO 2011]

[COCO 2011]

[COLLADA 2011]

[Crowther 2005]

[CU 2011]

[DATA 2011]

[DATAFED 2011]

[DC 2011]

[De Porcellinis 2008]

[DEVS 2011]

[DHS 2009]

[DHS 2010]

[DHS 2011a]
State and County QuickFacts. U.S. Census Bureau. Available via: http://quickfacts.census.gov/qfd/faq.html [accessed Mar. 25, 2011]. Topologically Integrated Geographic Encoding and Referencing System (TIGER). U.S. Census Bureau. Available via: http://www.census.gov/geo/www/tiger/ [accessed Mar. 25, 2011]. SIMULATIONS: CIP Simulations, Tools and Software. Center for Homeland Defense and Security. Naval Postgraduate School. Available via: https://www.chds.us/?media/resources\&collection=53\&type=SIMULATION [accessed Jan. 13, 2011].

Checkland, Peter. SSM: A Thirty-Year Retrospective. Systems Research and Behavioral Science, November 2000.

Cheng, Q., 2007, A fuzzy relation analysis method implemented in GIS for modeling infrastructure interdependency, in Geomatics Solutions for Disaster Management, J. Li, S. Zlatanova \& A. Fabbri (eds.), Springer Berlin, p. 351-367. Chicago Maps. Available via:

https://gisapps.cityofchicago.org/mapchicago/viewer.htm [accessed Mar. 25, 2011].

Community Collaborative Rain, Hail, and Snow Network (CoCoRaHS).

Available via: http://www.cocorahs.org/ [accessed Mar. 25, 2011].

Collaborative Design Activity (COLLADA): Digital Asset \& FX Exchange

Schema. Available via: https://collada.org/mediawiki/index.php/COLLADA [accessed Mar. 25, 2011].

Crowther, K. G. and Haimes, Y. Y. 2005. Application of the inoperability inputoutput model (IIM) for systemic risk assessment and management of interdependent infrastructures. Systems Engineering. Vol. 8, No. 4 (Nov. 2005), 323-341. DOI= http://dx.doi.org/10.1002/sys.v8:4.

United State -Mexico Data Collection (US-MEX): Census Data. Available via: http://www.ciesin.columbia.edu/repository/metadata/ig/Browse/UnitedStatesMexi coDataCollectionUSMEXCensusData.html [accessed Mar. 25, 2011].

Open Government Directive Agency Datasets. Available via: http://www.data.gov/open/raw [accessed Mar. 25, 2011].

DATAFed.NET for Effective Use of Aerosol Data. Available via: http://datafed.net/ [accessed Mar. 25, 2011].

DC Atlas: District of Columbia Geographic Information System. Available via: http://octo.dc.gov/DC/OCTO/Maps+and+Apps/Online+Mapping/All+Online+Ma ps/DC+Atlas+All-in-One+User+Guide [accessed Mar. 25, 2011].

De Porcellinis, S., R. Setola, S. Panzieri, and G. Ulivi, 2008. Simulation of heterogeneous and interdependent critical infrastructures. International Journal of Critical Infrastructures, 4(1-2), 110 - 128.

Discrete-Event Modeling and Simulation (DEVS) Standardization Group. Available via: http://cell-devs.sce.carleton.ca/devsgroup/ [accessed Jan. 25, 2011].

National Infrastructure Protection Plan. U.S. Department of Homeland Security. Available via: http://www.dhs.gov/xlibrary/assets/NIPP_Plan.pdf [accessed Feb. 27, 2011]

DHS Lexicon: Terms and Definitions. Office of the Secretary, Executive Secretariat, U.S. Department of Homeland Security. January 2010 edition (with 9/14/2010 update).

Chemical Sector Supply Chain and Economics Project. U.S. Department of Homeland Security. Available via:

http://www.dhs.gov/files/programs/gc_1218480826191.shtm\#8 [accessed Jan. 12, 
[DHS 2011b]

[DHS 2011c]

[DIESIS 2011]

[DoD 2006]

[DoD 2009]

[DoD 2010]

[DODCCRP 2011]

[DRDC 2009]

[Dudenhoeffer 2006]

[EDD 2011]

[EPA 2011a]

[EPA 2011b]

[ESRI 2011a]

[ESRI 2011b]
2011].

Sector-Specific Plans. U.S. Department of Homeland Security. Available via: http://www.dhs.gov/files/programs/gc_1179866197607.shtm [accessed Mar. 25, 2011].

Automated Critical Asset Management System (ACAMS). U.S. Department of Homeland Security. Available via:

http://www.dhs.gov/files/programs/gc_1190729724456.shtm [accessed Mar. 25, 2011].

Design of an Interoperable European federated Simulation network for critical infrastructures. Available via: http://www.diesis-project.eu/ [accessed Jan. 12, 2011].

VV\&A Recommended Practices Guide (RPG). U.S. Department of Defense Modeling and Simulation Coordination Office. RPG Build 3.0. September 2006. Available on-line via: http://vva.msco.mil/ [last accessed Oct. 1, 2010].

DoD Modeling and Simulation (M\&S) Verification, Validation, and

Accreditation (VV\&A). Department of Defense Instruction Number 5000.61.

December 9, 2009. Available on-line via:

http://www.dtic.mil/whs/directives/corres/pdf/500061p.pdf [last accessed October 4, 2010]

DoD Modeling and Simulation Glossary. U.S. Department of Defense. March 2010. Available via: http://www.msco.mil/files/Draft MS Glossary March_B version.pdf [accessed April 20, 2011]

http://www.dodccrp.org/events/2004_CCRTS/CD/presentations/172.pdf [Accessed Mar. 25, 2011]

Backgrounder - Government of Canada Invests \$2 Million to Bolster Canada's Safety and Security. Defence Research and Development Canada. April 6, 2009. Available via: http://www.css.drdc-rddc.gc.ca/publications/backgroundersdocumentation/2009 04 06-eng.asp [accessed Jan. 12, 2011].

Dudenhoeffer, D.D, M. R. Permann, and M. Manic, 2006. CIMS: A Framework For Infrastructure Interdependency Modeling And Analysis. In Proceedings of the 2006 Winter Simulation Conference, ed. L. F. Perrone, F. P. Wieland, J. Liu, B.

G. Lawson, D. M. Nicol, and R. M. Fujimoto. 478-485. Piscataway, New Jersey: Institute of Electrical and Electronics Engineers, 2006. Available via:

http://www.informs-sim.org/wsc06papers/058.pdf [accessed Jan. 12, 2011]. Electrical Distribution Design (EDD) Integrated Solutions. Available via: http://www.edd-us.com/ [accessed Jan. 12, 2011]. Computer-Aided Management of Emergency Operations (CAMEO). U.S. Environmental Protection Agency. Available via: http://www.epa.gov/emergencies/content/cameo/index.htm [accessed Mar. 25, 2011].

Envirofacts. U.S. Environmental Protection Agency. Available via: http://www.epa.gov/enviro/facts/multisystem.html [accessed Mar. 25, 2011]. ERSI Shapefile Technical Description. Environmental Systems Research Institute (ESRI), Inc. Available via: http://www.esri.com/library/whitepapers/pdfs/shapefile.pdf [accessed Mar. 25, 2011].

Geodatabase. Environmental Systems Research Institute (ESRI), Inc. Available via: http://www.esri.com/software/arcgis/geodatabase/index.html [accessed Mar. 25, 2011]. 
[ETSI 2011]

[FCC 2011]

[FGDC 2010]

[FGDC 2011a]

[FGDC 2011b]

[FGDC 2011c]

[FGDC 2011d]

[FGDC 2011e]

[GEOAPI 2011]

[GEOMAC 2011]

[GEOTIFF 2011]

[Gillette 2002]

[HL7 2011a]
Traffic Manage Channel (TMC) and Traffic Protocol Experts Group (TPEG) standards. Traveller Information Services Association. Available via: http://docbox.etsi.org//Workshop/2009/200902_ITSWORKSHOP/TISA_Hendric ks.pdf [accessed Mar. 25, 2011].

Connectionless data Bearer System (CDBS) Public Access. Federal Communications Commission (FCC). Available via: http://licensing.fcc.gov/prod/cdbs/pubacc/prod/cdbs_pa.htm [accessed Mar. 25, 2011].

Geographic Information Framework Data Standard. Federal Geographic Data Committee (FGDC). Available via:

http://www.fgdc.gov/standards/projects/FGDC-standards-projects/frameworkdata-

standard/GI_FrameworkDataStandard_Part5_GovernmentalUnitBoundaries.pdf [accessed Jan. 31, 2011].

Content Standard for Digital Geospatial Metadata. Federal Geographic Data Committee (FGDC). Available via:

http://www.fgdc.gov/standards/projects/FGDC-standards-projects/metadata/basemetadata/?searchterm=FGDC-STD-001 [accessed Mar. 25, 2011].

Content Standard for Digital Geospatial Metadata: Extensions for Remote Sensing Metadata. Federal Geographic Data Committee (FGDC). Available via: http://www.fgdc.gov/standards/projects/FGDC-standards-

projects/csdgm_rs_ex/MetadataRemoteSensingExtens.pdf/view?searchterm=FGD C-STD-012 [accessed Mar. 25, 2011].

Geographic Information Framework data Standard. Federal Geographic Data Committee (FGDC). Available via:

http://www.fgdc.gov/standards/projects/FGDC-standards-projects/frameworkdata-standard/framework-data-standard [accessed Mar. 25, 2011].

Spatial Data Transfer Standard (SDTS). Federal Geographic Data Committee (FGDC). Available via:

http://www.fgdc.gov/standards/projects/FGDC-standards-

projects/SDTS/?searchterm=sdts [accessed Mar. 25, 2011].

United States National Grid. Federal Geographic Data Committee (FGDC). Available via:

http://www.fgdc.gov/standards/projects/FGDC-standards-

projects/usng/fgdc_std_011_2001_usng.pdf [accessed Mar. 25, 2011].

GeoAPI 3.0 Standard. GeoAPI Standard Working Group. Available via:

http://www.geoapi.org/charter.html [accessed Mar. 25, 2011].

The Geospatial Multi-Agency Coordination Group (GeoMAC). Available via: http://www.geomac.gov/index.shtml [accessed Mar. 25, 2011].

GeoTIFF FAQ. Available via: http://www.remotesensing.org/geotiff/faq.html [accessed Mar. 25, 2011].

Gillette, J., R. Fisher, J. Peerenboom, R. Whitfield, 2002. Analyzing

Water/Wastewater Infrastructure Interdependencies. $6^{\text {th }}$ International Conference on Probabilistic Safety Assessment and Management, San Juan (PR), June 23-28. Available on-line: http://www.dis.anl.gov/pubs/42598.pdf [accessed Jan. 12, 2011].

HL7 Standards. Health level Seven International. Available via: http://www.hl7.org/implement/standards/index.cfm?ref=nav [accessed Mar. 25, 2011]. 
[HL7 2011b]

[HL7 2011c]

[HL7 2011d]

[HL7 2011e]

[IEEE 2011a]

[IEEE 2011b]

[IEEE 2011c]

[IEEE 2011d]

[IEEE 2011e]

[IEEE 2011f]

[IHS 2011]

[IHS2011a]

[IIIA 2007]

[INCOSE 2008]

[INL 2007]

[INL 2008]

[INL 2010]
Visual Integration/Clincial Context Object Workgroup (CCOW). Health level Seven International. Available via: http://www.hl7.org/implement/standards/ccow.cfm [accessed Mar. 25, 2011]. Clinical Document Architecture. Health level Seven International. Available via: http://www.hl7.org/implement/standards/cda.cfm [accessed Mar. 25, 2011]. HL7 Version 2.x Messaging Standard. Health level Seven International. Available via: http://www.hl7.org/implement/standards/v2messages.cfm [accessed Mar. 25, 2011].

HL7 Version 3 Messaging Standard. Health level Seven International. Available via: http://www.hl7.org/implement/standards/v3messages.cfm [accessed Mar. 25, 2011].

Guide for Implementing IEEE Standard 1512. IEEE. Available via:

http://grouper.ieee.org/groups/scc32/imwg/guide.pdf [accessed Mar. 25, 2011].

IEEE Standard for Data Dictionaries for Intelligent Transportation Systems. IEEEXplore. Available via:

http://ieeexplore.ieee.org/xpl/freeabs_all.jsp?arnumber=803526 [accessed Mar. 25, 2011].

IEEE Standard for Modeling and Simulation (M\&S) High Level Architecture (HLA). IEEEXplore. Available via:

http://ieeexplore.ieee.org/xpl/freeabs_all.jsp?arnumber=803526 [accessed Mar. 28, 2011].

IEEE Safety and Security Standards Series, Vol.2, Computers and Networks. IEEE. Available via: http://www.safetyonline.com/product.mvc/IEEE-Safety-andSecurity-Standards-Series-Vol-0001 [accessed Mar. 25, 2011].

IEEE Safety and Security Standards Series, Vol.3, Electrical. IEEE. Available via: http://www.safetyonline.com/product.mvc/IEEE-Safety-and-SecurityStandards-Series-Vol-0002 [accessed Mar. 25, 2011].

IEEE Safety and Security Standards Series, Vol.1, Critical Infrastructure. IEEE. Available via: http://www.safetyonline.com/product.mvc/IEEE-Safety-andSecurity-Standards-Series-Vol-0003 [accessed Mar. 25, 2011].

2006 U.S. DOT Releases New Standards Fact Sheets. IHS. Available via: http://auto.ihs.com/news/2006/dot-fact-sheets.htm [accessed Mar. 25, 2011]. IEEE 1278.2 Standard for Distributed Interactive Simulation - Communication Services and Profiles. IHS. Available via: http://electronics.ihs.com/document/abstract/ZEVZCBAAAAAAAAAA [accessed Jan. 28, 2011].

Our Research Projects. Institute for Infrastructure and Information Assurance, Harrisonburg, VA. Available via:

http://www.jmu.edu/iiia/research/research_current.html [accessed Jan. 13, 2011]. International Council on Systems Engineering. INCOSE-TD-2007-003-01: Survey of Model-Based Systems Engineering (MBSE) Methodologies. Seattle, WA 98133. 10 June 2008.

CIMSuite: Critical Infrastructure Modeling. Idaho National Laboratory. Available on-line: http://www.inl.gov/factsheets/docs/cimsuite.pdf [accessed Jan. 12, 2011].

Protecting the Nation's Infrastructure: The Idaho Test Range. Idaho National Laboratory. Available via:

http://www.inl.gov/nationalsecurity/factsheets/docs/critical infrastructure test ra nge.pdf [accessed Jan. 12, 2011].

Modeling and Simulation. Idaho National Laboratory. Available via: https://inlportal.inl.gov/portal/server.pt/community/national_and_homeland_secur ity/273/modeling_and_simulation/1707 [accessed Jan. 13, 2011]. 
[IntePoint 2008]

[ISO 2011a]

[ISO 2011b]

[ISO 2011c]

[ISO 2011d]

[Jain 2011]

[LACOUNTY 2011]

[Lee 2005]

[Li 2009]

[LLNL 2011]

[Martin 1996]

[MCMD 2011]

[NASA 2011]

[NCDC 2011a]

[NCDC 2011b]

[NEMSIS 2011]
IntePoint Vu. IntePoint. Available via: http://intepoint.com/solutions/index.html [accessed Jan. 13, 2011]. NEW ISO Standard for Building Escape and Evacuation Plans is a Potential Life Saver. ISO. Available via:

http://www.iso.org/iso/pressrelease.htm?refid=Ref1207 [accessed Jan. 15, 2011]. ISO Standards. ISO. Available via: http://www.iso.org/iso/iso_catalogue.htm [accessed Mar. 25, 2011].

ISO 15628 Road Transport and Traffic Telematics - Dedicated Short range Communication (DSRC) - DSRC Application Layer. ISO. Available via: http://engineers.ihs.com/document/abstract/RLWQXBAAAAAAAAAA [accessed Mar. 25, 2011].

Electronic data Interchange for Administration, Commerce and Transport (EDIFACT). ISO. Available via:

http://www.iso.org/iso/catalogue_detail.htm?csnumber=37020 [accessed Mar. 25, 2011].

Jain, S., and C.R. McLean. 2011. Best Practices for Modeling, Simulation and Analysis (MS\&A) for Homeland Security Applications. National Institute of Standards and Technology. NIST Interagency/Internal Report (NISTIR) 7655. GIS-NET. Los Angeles County. Available via: http://planning.lacounty.gov/gisnet [accessed Mar. 25, 2011].

Lee, E., A. Wallace, J.E. Mitchell and D. Mendonça. 2005. Decision technologies for protection of critical infrastructures. In Proceedings of Working Together: R\&D Partnerships in Homeland Security, Boston, May 2005. Available via: http://www.rpi.edu/ mitchj/papers/decisiontechnologies.html [accessed Jan. 13, 2011].

Li, H., Apostolakis, G.E., Gifun, J., VanSchalkwyk, W., Leite, S., and Barber, D. 2009. Ranking the Risks from Multiple Hazards in a Small Community. Risk Analysis, 29:438-456, 2009.

DYNA3D. Methods Development Group. Lawrence Livermore National Laboratory. Available via: https://wwweng.llnl.gov/mdg/mdg codes dyna3d.html [accessed Jan. 12, 2011]. Martin, James N., Systems Engineering Guidebook: A Process for Developing Systems and Products, CRC Press, Inc.: Boca Raton, FL, 1996.

Montgomery County Government Map Viewer. Montgomery County, Maryland. Available via: http://gis2.montgomerycountymd.gov/ims/mcgmaps/viewer.htm [accessed Mar. 25, 2011].

EOS Data Gateway (EDG). NASA. Available via:

http://outreach.eos.nasa.gov/EOSDIS_CD-02/docs/edgsteps.htm [accessed Mar. 25, 2011].

National Environmental Satellite, Data, and Information Service ((NESDIS): Data Access Tools. NOAA. Available via:

http://www.ncdc.noaa.gov/oa/dataaccesstools.html [accessed Mar. 25, 2011].

National Environmental Satellite, Data, and Information Service ((NESDIS):

Metadata Resources. NOAA. Available via:

http://www.ncdc.noaa.gov/oa/metadata/metadataresources.html\#ports [accessed Mar. 25, 2011].

National EMS Information System (NEMSIS). Intermountain Injury Control Research Center, Salt Lake City, UT. Available via:

http://www.nemsis.org/theProject/whatIsNEMSIS/index.html [accessed Mar. 25, 2011]. 
[NFPA 2011]

[NGA 2011]

[NGDC 2011]

[NI2CIE 2009]

[NIEM 2011]

[NISAC 2007]

[NISAC 2011a]

[NISAC 2011b]

[NISAC 2011c]

[NISAC 2011d]

[NISAC 2011e]

[NISAC 2011f]

[NISAC 2011g]

[NISAC 2011h]

[NISAC 2011i]

[NISAC 2011j]

[NMAP 2011]
NFPA Catalog. National Fire Protection Association (NFPA). Available via: http://www.nfpa.org/catalog/ [accessed Mar. 25, 2011].

Military Standard Vector Product Format (VPF). Department of Defense. Available via: http://earth-info.nga.mil/publications/specs/printed/VPF/vpf.html [accessed Mar. 25, 2011].

National Geophysical Data Center. NOAA. Available via: http://www.ngdc.noaa.gov/ngdcinfo/accesssystems.html [accessed Mar. 25, 2011].

CARVER2. National Infrastructure Institute - Center for Infrastructure Expertise, Portsmouth, NH. Available via: http://www.ni2cie.org/CARVER2.asp [accessed Jan. 12, 2011].

National Information Exchange Model (NIEM). NIEM.gov. Available via: http://www.niem.gov/ [accessed Jan. 24, 2011].

Uncertainty Analysis of Pandemic Influenza Impacts on National Infrastructure: Supplement to the National Population and Infrastructure Impacts of Pandemic Influenza Report. National Infrastructure Simulation \& Analysis Center, Infrastructure Analysis and Strategy Division Office of Infrastructure Protection, U.S. Department of Homeland Security, 15 October 2007. Available via: www.sandia.gov/nisac/docs/UncertaintyAnalysis.doc [accessed Jan. 12, 2011]. National Infrastructure Simulation \& Analysis Center. Available via: http://www.sandia.gov/nisac/ [accessed Jan. 12, 2011].

Network Optimization Models. National Infrastructure Simulation \& Analysis Center. Available via: http://www.sandia.gov/nisac/net_op.html [accessed Jan. 12, 2011].

Fast Analysis Infrastructure Tool (FAIT). National Infrastructure Simulation \& Analysis Center. Available via: http://www.sandia.gov/nisac/fait.html [accessed Jan. 13, 2011].

Interdependent Environment for Infrastructure System Simulations (IEISS).

National Infrastructure Simulation \& Analysis Center. Available via: http://www.sandia.gov/nisac/ieiss.html [accessed Jan. 13, 2011].

Advanced Modeling \& Techniques Investigation (AMTI). National Infrastructure Simulation \& Analysis Center. Available via:

http://www.sandia.gov/nisac/amti.html [accessed Jan. 13, 2011].

Multi-Scale Integrated Information and Telecommunications System (MIITS).

National Infrastructure Simulation \& Analysis Center. Available via:

http://www.sandia.gov/nisac/miits.html [accessed Jan. 13, 2011].

NISAC Agent Based Laboratory for Economics (N-ABLE). National Infrastructure Simulation \& Analysis Center. Available via:

http://www.sandia.gov/nisac/nable.html [accessed Jan. 13, 2011].

Transportation Analysis Simulation System (TRANSIMS). National

Infrastructure Simulation \& Analysis Center. Available via:

http://www.sandia.gov/nisac/transims.html [accessed Jan. 13, 2011].

Urban Infrastructure Suite (UIS). National Infrastructure Simulation \& Analysis

Center. Available via: http://www.sandia.gov/nisac/uis.html [accessed Jan. 13, 2011].

Water Infrastructure Simulation Environment (WISE). National Infrastructure

Simulation \& Analysis Center. Available via:

http://www.sandia.gov/nisac/wise.html [accessed Jan. 13, 2011].

The National Map. U.S. Geological Survey. Available via:

http://nationalmap.gov/ [accessed Mar. 25, 2011]. 
[NREL 2011]

[NTCIP 2011]

[NWS 2011a]

[NWS 2011b]

[OASIS 2011a]

[OASIS 2011b]

[OGC 2011a]

[OGC 2011b]

[OGC 2011c]

[OGC 2011d]

[OGC 2011e]

[OGC 2011f]

[OGC 2011g]

[OMG 2011]

[ORNL 2004]

[ORNL 2006]

[Outkin 2006]

[Pederson 2006]
Dynamic Maps, GIS Data, and Analysis Tools. National Renewable Energy Laboratory. Available via: http://www.nrel.gov/gis/about.html [accessed Mar. 25, 2011].

The National Transportation Communications for ITS Protocol (NTCIP) ONLINE Resource. NTCIP. Available via: http://www.ntcip.org/library/documents/ [accessed Mar. 25, 2011]. National Digital Forecast Database. National Weather Service. Available via: http://www.nws.noaa.gov/ndfd/ [accessed Mar. 25, 2011].

File/Web Services Retrieval Procedures. National Weather Service. Available via: http://www.nws.noaa.gov/tg/dataprod.html [accessed Mar. 25, 2011].

Common Alert Protocol (CAP). Organization for the Advancement of Structured Information Standards (OASIS). Available via: http://www.oasisemergency.org/cap [accessed Jan. 15, 2011].

Emergency Data Exchange Language (EDXL). Organization for the Advancement of Structured Information Standards (OASIS). Available via: http://xml.coverpages.org/edxl.html [accessed Mar. 25, 2011].

CityGML: OpenGIS City Geography Markup Language Encoding Standard. Open Geospatial Consortium, Inc. (OGC). Available via:

http://www.opengeospatial.org/standards/citygml [accessed Jan. 15, 2011].

OGC KML. Open Geospatial Consortium, Inc. (OGC). Available via: http://www.opengeospatial.org/standards/kml [accessed Mar. 25, 2011].

Simple Feature Access. Open Geospatial Consortium, Inc. (OGC). Available via: http://www.opengeospatial.org/standards/sfa [accessed Mar. 25, 2011]. Tiger/GML TM - U.S. Census. Open Geospatial Consortium, Inc. (OGC). Available via: http://www.ogcnetwork.net/node/220 [accessed Mar. 25, 2011]. Web Coverage Service (WCS). Open Geospatial Consortium, Inc. (OGC). Available via: http://www.opengeospatial.org/standards/wcs [accessed Mar. 25, 2011].

OpenGIS Web Feature Service (WFS) Implementation Specification. Open Geospatial Consortium, Inc. (OGC). Available via: http://www.opengeospatial.org/standards/wfs [accessed Mar. 25, 2011]. OpenGIS Web Map Service (WMS) Implementation Specification. Open Geospatial Consortium, Inc. (OGC). Available via: http://www.opengeospatial.org/standards/wms [accessed Mar. 25, 2011]. OMG Systems Modeling Language (SysML). Object Management Group, Inc. (OMG). Available via: http://omgsysml.org/ [accessed Mar. 25, 2011]. Visual Interactive Site Analysis Code (VISAC). Oak Ridge National Laboratory. Available via: http://visac.ornl.gov/ [accessed Jan. 13, 2011].

WebTRAGIS: Transportation Routing Analysis Geographic Information System. Oak Ridge National Laboratory. Available via: https://tragis.ornl.gov/ [accessed Jan. 13, 2011].

Outkin, A. and S. Flaim, 2006. FinSim: Financial Infrastructure as a Complex Decentralized System. $26^{\text {th }}$ Annual Conference of Center for Nonlinear Studies Socio-Technical Systems: Bridging the Scales. August 14-18, Oppenheimer Center, Los Alamos National Laboratory, Los Alamos, NM, USA. Abstract available via: http://cnls.lanl.gov/annual26/abstracts.html [accessed March 11, 2010].

Pederson, P., D. Dudenhoeffer, S. Hartley, and M. Permann. 2006. Critical Infrastructure Interdependency Modeling: A Survey of U.S. and International Research. August 2006. Idaho National Laboratory. Available via: http://www.inl.gov/technicalpublications/Documents/3489532.pdf [accessed 
[Powell 2007]

[PUCO 2011]

[Rinaldi 2004]

[SAE 2011a]

[SAE 2011b]

[SAIC 2011]

[SEDRIS 2011a]

[SEDRIS 2011b]

[SERRI 2007]

[SFGOV 2011]

[Shih 2009]

[Sveen 2010]

[TISN 2010]

[TSS 2010]

[UBC 2007]

[Uddin 2009]
Jan.12, 2011].

Powell, D., B. Bush, L. Dauelsberg, D. LeClaire, S. DeLand, and M. Samsa, 2007. Critical Infrastructure Protection Decision Support System Overview. Los Alamos National Laboratory report LAUR-07-1769.

Public Utilities Commission Interactive Maps. The Public Utilities Commission of Ohio. Available via:

http://www.puco.ohio.gov/PUCO/GIS/MapInfo.cfm?id=5754 [accessed Mar. 25, 2011]

Rinaldi, Stephen M. Modeling and Simulating Critical Infrastructures and Their Interdependencies. Proceedings of the $37^{\text {th }}$ Hawaii International Conference on System Sciences. Big Island, Hawaii, 5-8 January 2004.

On-Board Land Vehicle Mayday Reporting Interface. SAE International. Available via: http://standards.sae.org/j2313_199909/ [accessed Mar. 25, 2011]. Converting Atis Message Standards from Asn.1 to XML. SAE International. Available via:

http://www.sae.org/servlets/works/documentHome.do?comtID=TEITSATIS\&doc ID=J2630_200312\&inputPage=dOcDeTaIlS [accessed Mar. 25, 2011].

Integrated Water Quality Security System (IWQSS). Science Applications International Corporation (SAIC). Available via: http://eh2o.saic.com/iwqss/ [accessed Jan. 13, 2011]

The Source for Environmental Data Requirement \& Interchange. SEDRIS.org. Available via: http://sedris.org/ [accessed Mar. 25, 2011].

SEDRIS Data. SEDRIS.org. Available via: http://data.sedris.org/ [accessed Mar. 25, 2011].

Fact Sheet: South East Regional Research Initiative, Department of Homeland Security. Available via:

http://www.serri.org/publications/Documents/Ole\%20Miss\%20Project\%2063888 \%20Fact\%20Sheet\%20on\%20Particle\%20Dynamics\%20Simulation\%20(Cheng). pdf. [accessed Jan. 12, 2011].

San Francisco Enterprise GIS Program. City and County of San Francisco. Available via: http://gispub02.sfgov.org/ [accessed Mar. 25, 2011].

Shih, C.Y., C.D. Scown, L. Soibelman, H.S. Matthews, J.H. Garrett Jr., K. Dodrill, and S. McSurdy, 2009. Data Management for Geospatial Vulnerability Assessment of Interdependencies in U.S. Power Generation. Journal of Infrastructure Systems, Vol. 15, No. 3, September. 179-189.

Sveen, F.O., E. Rich, J.M. Torres, J. Hernantes, and J.J. Gonzalez, 2010. A Group Model Building Approach for Identifying Simulation Scenarios in Critical Infrastructure. $43^{\text {rd }}$ Hawaii International Conference on System Sciences. Koloa, Kauai, Hawaii, January 05-January 08.

TISN for Critical Infrastructure Resilience: Modelling and Analysis. Trusted Information Sharing Network (TISN), Commonwealth of Australia. Available via: http://www.tisn.gov.au/www/tisn/content.nsf/Page/Modelling_and_analysis [accessed Jan. 12, 2011].

Aimsun: The Integrated Transport Modeling Software. Transport Simulation Systems. Available via: http://www.aimsun.com/site/ [accessed Jan.12, 2011]. Infrastructure Interdependencies Simulation (I2SIM) Team. University of British Columbia, Canada. http://www.ece.ubc.ca/ jiirp/ [accessed Jan. 13, 2011]. Uddin, M.Y.S., D. Nicol, T. Abdelzaher, and R. Kravets, 2009. A Post-Disaster Mobility Model for Delay Tolerant Networking. In Proceedings of the 2009 Winter Simulation Conference, eds. M. D. Rossetti, R. R. Hill, B. Johansson, A. Dunkin, and R. G. Ingalls, Piscataway, NJ: IEEE. 2785-2796. 
[UIC 2011]

[UMD 2011]

[USACE 2010]

[USACE 2011]

[USFA 2011]

[USGS 2011a]

[USGS 2011b]

[USGS 2011c]

[UWA 2011]

[Walsh 2009]

[WCNY 2011]

[WEB3D 2011a]

[WEB3D 2011b]

[WHO 2011a]

[WHO 2011b]

[WHO 2011c]
National Emergency Medical Services Information System (NEMSIS). U.S. Department of Transportation. Available via:

http://www.uic.edu/depts/glstrknet/doc/NEMSIS_Data_Dictionary_v2.2.1.pdf [accessed Mar. 25, 2011].

Global Terrorism Database. National Consortium for the Study of Terrorism and Responses to Terrorism (START). Available via: http://www.start.umd.edu/gtd/about/GTDTeam.aspx [accessed Mar. 25, 2011]. Fort Future Utilities Analysis Tools. Engineering Research and Development Center, U.S. Army Corps of Engineers. Available via: http://www.cecer.army.mil/td/tips/product/details.cfm?ID=736 [accessed Jan. 13, 2011].

Discrete Element Modeling of Debris, Ice, Barges, and Tows. Engineering Research and Development Center, U.S. Army Corps of Engineers. Available via:

http://www.erdc.usace.army.mil/pls/erdcpub/docs/erdc/images/Discrete_Element _Modeling_of_debris.pdf [accessed Jan. 12, 2011].

National Fire Department Census. U.S. Fire Administration. Available via http://www.usfa.dhs.gov/applications/census/ [accessed Mar. 25, 2011].

USGS Response to an Urban Earthquake Northridge '94. U.S. Geological Survey. Available via: http://pubs.usgs.gov/of/1996/ofr-96-0263/commun.htm [accessed Jan. 15, 2011].

National Geochemical Survey Database. U.S. Geological Survey. Available via: http://tin.er.usgs.gov/geochem/ [accessed Mar. 25, 2011]

The Geographic Names Information System (GNIS). U.S. Geological Survey. Available via: http://geonames.usgs.gov/domestic/index.html [Accessed Mar. 25, 2011]

Spatial Data Modelling Language (SDML). Available via: http://local.wasp.uwa.edu.au/ pbourke/dataformats/sdml/index.html [accessed Mar. 25, 2011].

Walsh, S., S. Cherry, and L. Roybal, 2009. Critical infrastructure modeling: an approach to characterizing interdependencies of complex networks \& control systems. In Proceedings of the $2^{\text {nd }}$ Conference on Human System interactions (Catania, Italy, May 21 - 23, 2009). IEEE Press, Piscataway, NJ, 634-638.

Geographic Information Systems: Mapping Westchester County. Westchester County. Available via: http://giswww.westchestergov.com/gismap/default.aspx? [accessed Mar. 25, 2011].

The Virtual Reality Modeling Language (VRML). Available via: http://www.web3d.org/x3d/specifications/vrml/VRML1.0/index.html [accessed Mar. 25, 2011].

X3D. Web/3D Consortium. Available via:

http://www.web3d.org/about/overview/ [accessed Mar. 25, 2011].

Communicable Disease Surveillance and Response Systems. World Health

Organization. Available via:

http://www.who.int/csr/resources/publications/surveillance/WHO_CDS_EPR_LY O_2006_1.pdf [accessed Mar. 25, 2011].

WHO Pandemic Phase Descriptions and Main Actions by Phase. World Health Organization. Available via:

http://www.who.int/csr/resources/publications/surveillance/WHO_CDS_EPR_LY O_2006_2.pdf [accessed Mar. 25, 2011].

World Health Organization. Available via:

http://www.who.int/csr/disease/influenza/pandemic_phase_descriptions_and_acti 
[WHO 2011d] Global Alert and Response (GAR): Protocol for the Assessment of National Communicable Disease Surveillance and Response Systems. Guidelines for Assessment Teams. World Health Organization. Available via: http://www.who.int/csr/resources/publications/surveillance/WHO_CDS_CSR_IS R_2001_2_EN/en/ [accessed Mar. 25, 2011].

[WHO 2011e] Global Alert and Response (GAR): WHO SARS Risk Assessment and Preparedness Framework October 2004. World Health Organization. Available via:

http://www.who.int/csr/resources/publications/WHO_CDS_CSR_ARO_2004_2/e n/index.html [accessed Mar. 25, 2011].

[WMO 2010a] A Guide to the Code Form FM 92-IX Ext. GRIB. World Health Organization. Available via: http://www.wmo.int/pages/prog/www/WDM/Guides/Guidebinary-2.html [accessed Nov. 3, 2010].

[Zhang 2005] Zhang, P., Peeta, S., and Friesz, T. 2005. "Dynamic Game Theoretic Model of Multi-Layer Infrastructure Networks,” Networks and Spatial Economics, Vol. 5, No. 2, pp. 147-178. 